INTER NATIONAL MONETARY FUND

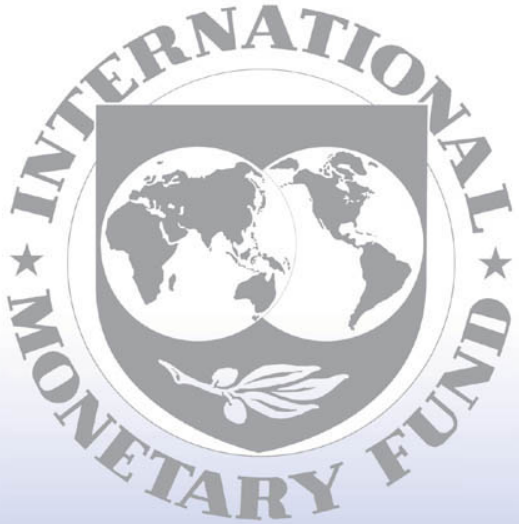

Staff

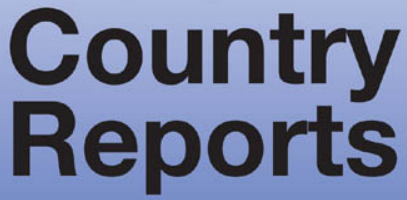




\section{Czech Republic: 2007 Article IV Consultation-Staff Report; Public Information Notice on the Executive Board Discussion; and Statement by the Executive Director for the Czech Republic}

Under Article IV of the IMF's Articles of Agreement, the IMF holds bilateral discussions with members, usually every year. In the context of the Article IV consultation with the Czech Republic, the following documents have been released and are included in this package:

- $\quad$ The staff report for the 2007 Article IV consultation, prepared by a staff team of the IMF, following discussions that ended on November 20, 2007, with the officials of the Czech Republic on economic developments and policies. Based on information available at the time of these discussions, the staff report was completed on January 7, 2008. The views expressed in the staff report are those of the staff team and do not necessarily reflect the views of the Executive Board of the IMF.

- $\quad$ A Public Information Notice (PIN) summarizing the views of the Executive Board as expressed during its January 23, 2008 discussion of the staff report that concluded the Article IV consultation.

- $\quad$ Statement by the Executive Director for the Czech Republic.

The document listed below has been or will be separately released.

Selected Issues Paper

The policy of publication of staff reports and other documents allows for the deletion of market-sensitive information.

To assist the IMF in evaluating the publication policy, reader comments are invited and may be sent by e-mail to publicationpolicy@imf.org.

Copies of this report are available to the public from

International Monetary Fund • Publication Services

$70019^{\text {th }}$ Street, N.W. • Washington, D.C. 20431

Telephone: (202) 623-7430 • Telefax: (202) 623-7201

E-mail: publications@imf.org • Internet: http://www.imf.org

Price: $\$ 18.00$ a copy

\section{International Monetary Fund}

Washington, D.C. 
This page intentionally left blank

CInternational Monetary Fund. Not for Redistribution 
INTERNATIONAL MONETARY FUND

\section{CZECH REPUBLIC}

\section{Staff Report for the 2007 Article IV Consultation}

Prepared by the Staff Representatives for the 2007 Consultation with the Czech Republic

Approved by Alessandro Leipold and G. Russell Kincaid

January 7,2008

\section{Executive Summary}

The Czech economy continues to perform well and external vulnerabilities are limited. The growth momentum has been sustained and the economy has so far weathered the recent market turmoil well. External debt is low and the modest current account deficit is comfortably financed by direct investment flows. While the koruna has appreciated sharply in recent months, it is estimated to be broadly in line with fundamentals.

Growth, while still robust, is likely to slow in 2008 and inflation expected to rise sharply. Downside risks to growth stem primarily from external sources. Headline inflation is set to double due to a series of shocks arising from indirect taxes as well as food and energy price increases. Strong demand on resources is also increasing underlying inflation.

Monetary policy needs to be on a sustained tightening path. The appropriate pace of tightening will depend on the degree of koruna appreciation and second-round effects of indirect tax and energy price increases. The Czech National Bank's high credibility, and recent steps to enhance transparency of policy communication, should serve to anchor inflation expectations. This would also facilitate the transition to the lower inflation target of 2 percent from 2010.

The main medium-term policy challenge centers on achieving sustainable fiscal consolidation. The authorities plan to lower the deficit below the Maastricht threshold limit from 2008 onwards. Building on the considerably better-than-budgeted outcome in 2007 , the authorities should maintain the originally targeted adjustment for 2008. Beyond that, there was broad consensus that the recently approved tax and welfare reform package, while introducing some welcome changes in the tax structure, does not sufficiently advance fiscal consolidation. Comprehensive pension and health care reforms, implemented early, will be essential for sustainable public finances. Absent such reforms, tax cuts can be ill afforded. Labor market reforms could also help alleviate fiscal adjustment. 


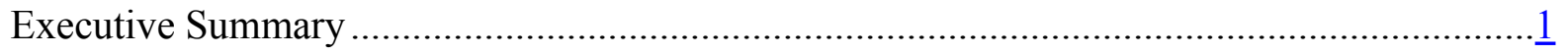

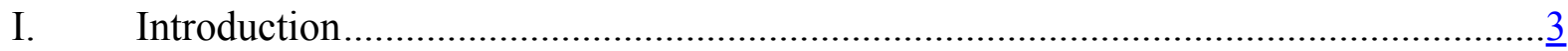

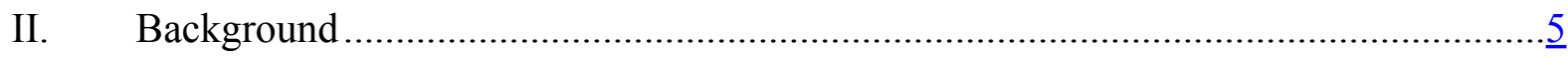

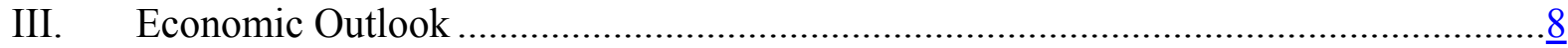

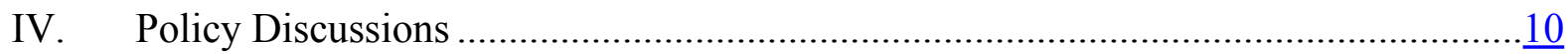

A. Ensuring Sustainable Public Finances ……………........................................

B. Monetary Policy Conduct and Communication ..................................................13

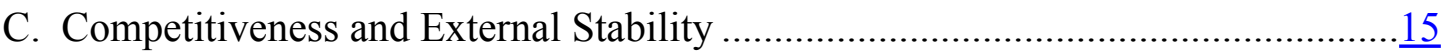

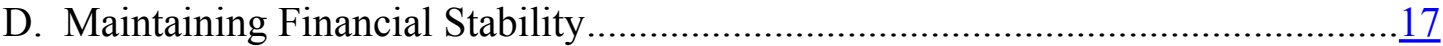

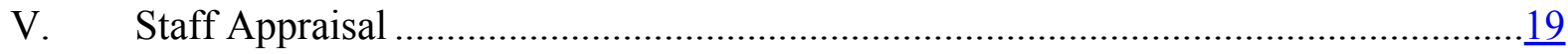

\section{Boxes}

1. The Tax and Welfare Reform Package: Key Measures...................................................11

2. Is the Czech Koruna Funding Carry Trades? ..............................................................

Figures

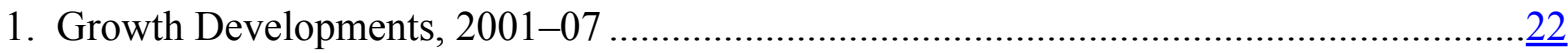

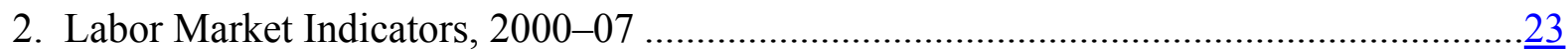

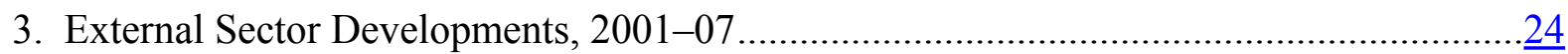

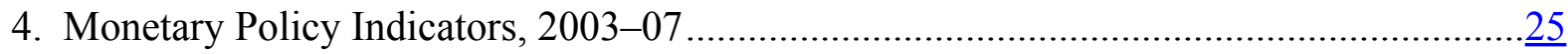

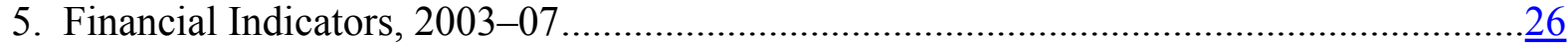

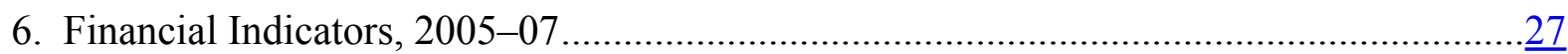

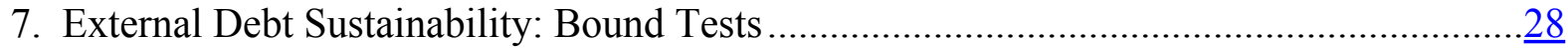

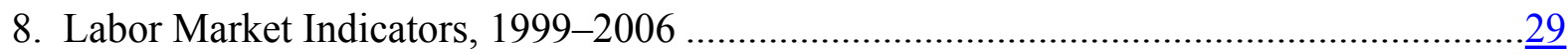

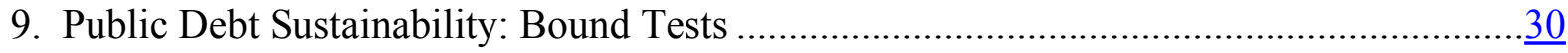

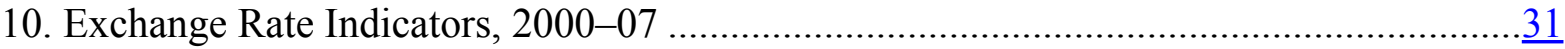

11. Wages and Productivity in Manufacturing, 2000-07 .....................................................

Tables

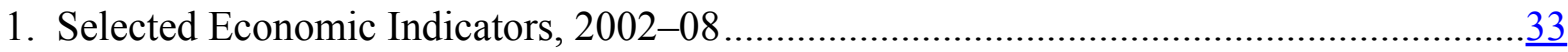

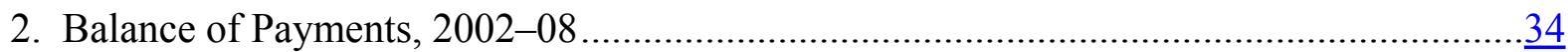

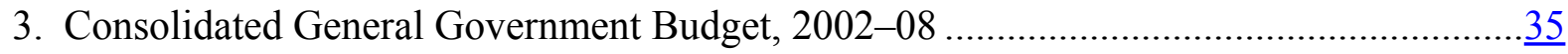

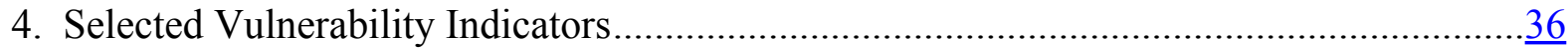

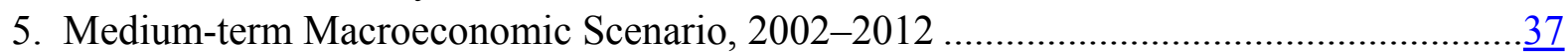

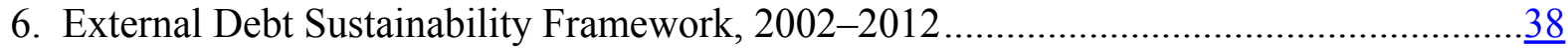

7. Public Sector Debt Sustainability Framework, 2002-2012 ….......................................... 


\section{INTRODUCTION ${ }^{1}$}

1. Reaping the benefits of EU integration and prudent macroeconomic policies, the Czech Republic has made solid strides toward convergence with the EU-15. Over the past few years, growing trade linkages fostered by strong direct investment inflows, coupled with a regional cyclical upswing, have underpinned an export-led boom, accompanied by low inflation and an improving external balance. Reassured by these strong fundamentals, market sentiment has remained benign, allowing the economy to tide over an extended political gridlock ${ }^{2}$ and global market turmoil with fairly low financial market and exchange rate volatility.

\section{Sustaining this growth momentum with external stability will require addressing} the key challenge of fiscal consolidation. This is also a prerequisite to ensuring smooth euro entry. With one of the highest primary fiscal deficits in the region and large demographic shifts underway, structural fiscal and pension reform remains a key priority to restore longer run debt sustainability and improve incentives to work. Labor market reforms to reduce structural unemployment, and increase flexibility and participation could make a substantial contribution to reducing the fiscal gap and enhancing income convergence. Given the importance of building a social consensus on durable fiscal consolidation measures, staff organized, jointly with the authorities, a conference on the fiscal reform agenda with participation by representatives from the public and private sectors and the academic community.

\footnotetext{
${ }^{1}$ A staff team comprising Mr. Thakur (head), Mr. Dalsgaard, Ms. Muñoz, and Ms. Tuladhar (all EUR) held discussions in Prague during November 8-20. Mr. Polak (Senior Advisor to the Executive Director) joined the discussions. Messrs. Rosenberg and Tirpak from the Regional Representative's office also participated. The Czech Republic has accepted the obligations of Article VIII of the Articles of Agreement and maintains an exchange system that is free of restrictions on the making of payments and transfers for current international transactions and subscribes to the SDDS.
}

${ }^{2}$ Following an indecisive election outcome in June 2006, a center-right coalition took office in January 2007 with the support of two opposition members. 
Czech Republic and CEECs: Comparative Macroeconomic Developments, 2000-07

Over the past few years, growth has accelerated...

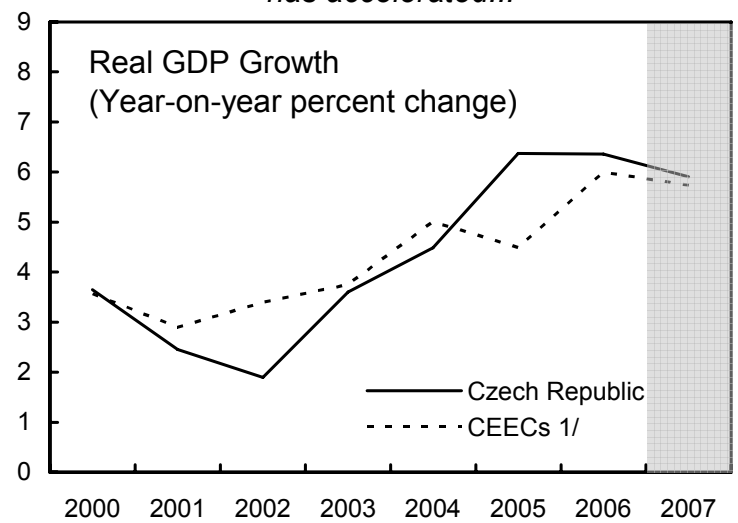

Inflation has remained low...

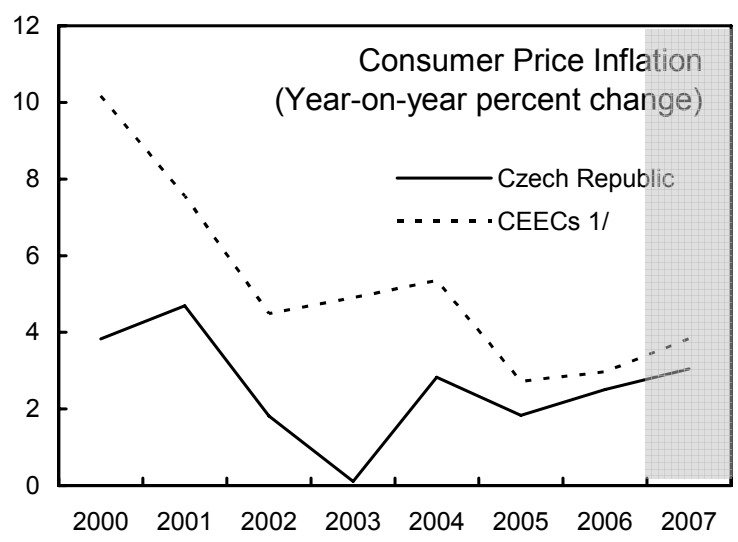

The Czech Republic is relatively more open with strong FDI inflows.

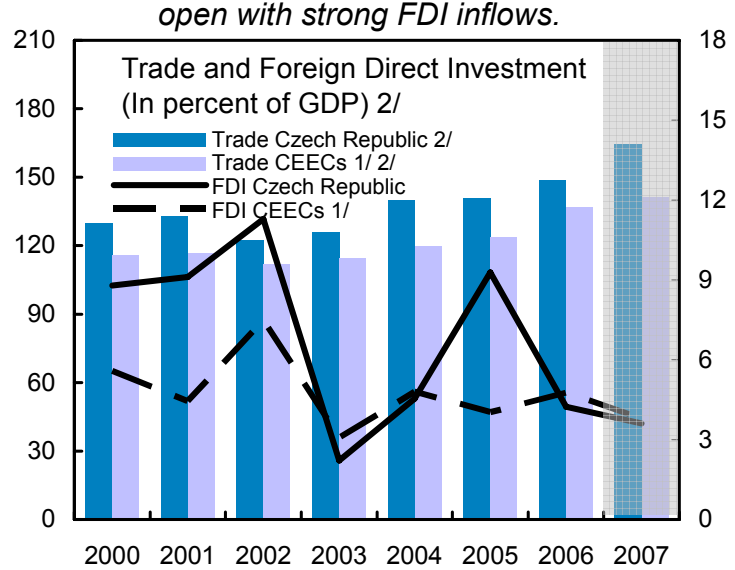

...while external balances improved.

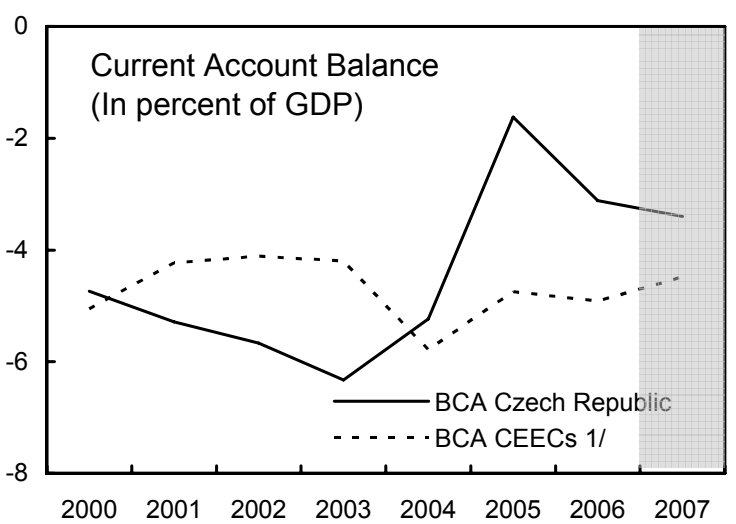

...and unemployment has declined.

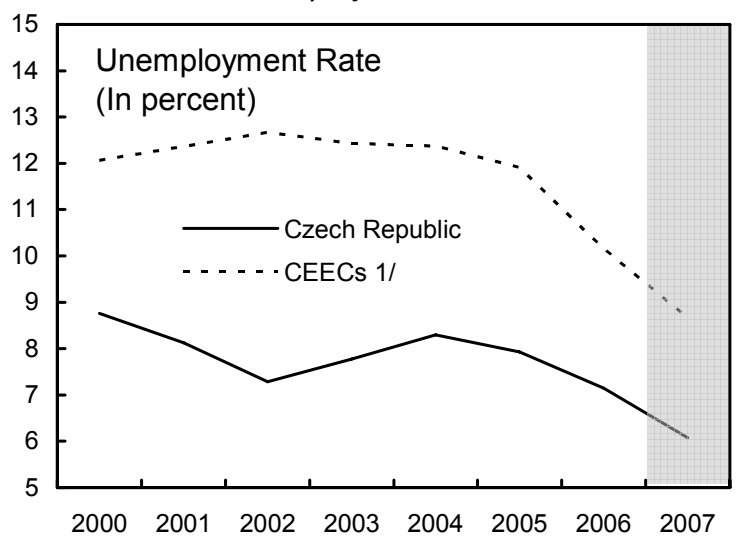

Although debt is low, deficits remain relatively high.

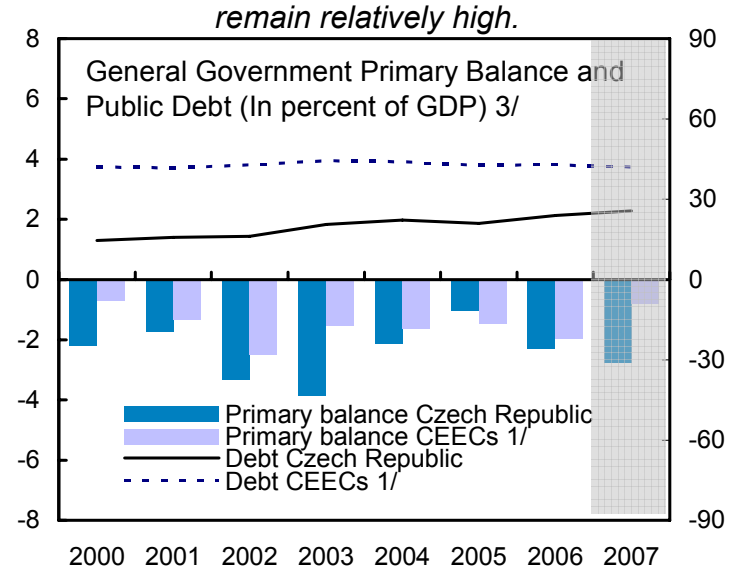

Sources: WEO; Eurostat; and IMF staff estimates.

1/ Average for Hungary, Poland, the Slovak Republic, and Slovenia.

2/ Trade is defined as exports plus imports of goods and services and is measured on the left scale. Net foreign direct investment is measured on the right scale.

$3 /$ Primary balance is measured on the left scale and public debt on the right scale. 


\section{BACKGROUND}

3. A strong cyclical upswing continued apace in 2007. GDP growth is likely to be sustained at close to 6 percent for the third year in a row, driven by domestic demand (Figure 1 and Table 1). While export growth has remained robust, led by the automobile sector, strong corporate profitability has fuelled fixed investment. Consumption has remained strong, reflecting rising disposable earnings from strong wage gains, higher social transfers and rapid credit expansion.

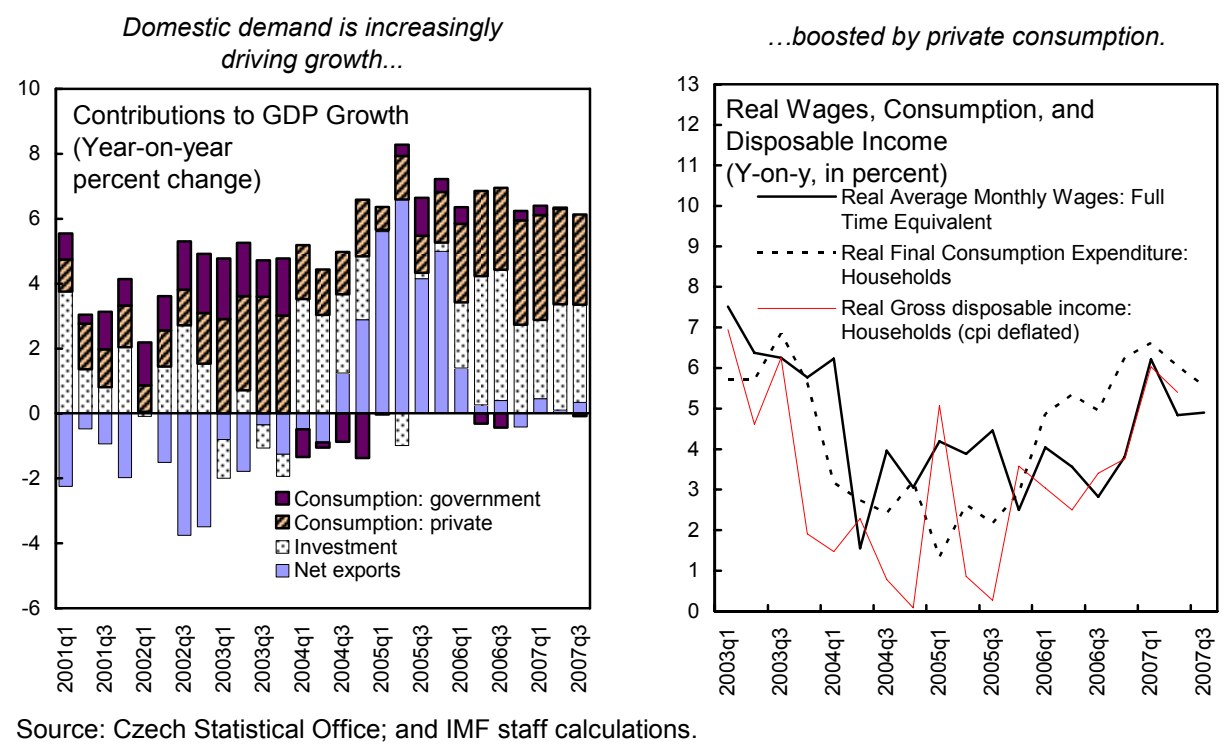

4. Rapid growth has begun to stretch capacity limits (Figure 2). The unemployment rate has declined to the lowest level this decade, marked by a decline in both short and long term unemployment. With labor shortages emerging despite a steady rise in immigration, wage gains are rapidly catching up with strong productivity growth, squeezing profitability margins. Capacity utilization rates in industry also stand at record high levels. Estimates of output gap measures also point to a positive gap in 2007.

5. The current account deficit has widened, but remains largely financed by inflows of direct investment (Figure 3). Although the saving rate remains relatively high, the pickup in investment led to a rise in the current account deficit to around $3 \frac{1}{2}$ percent of GDP in 2007 from about 3 percent in 2006 (Table 2). Trade and services balance surpluses continued to improve on account of strong exports of the automobile and electronic sectors. However, with record profits, these were offset by a sharp rise in repatriation of dividends by foreign investors.
The current account deficit has widened in 2006-07 as profit repatriations rose but has been adequately financed by FDI flows.

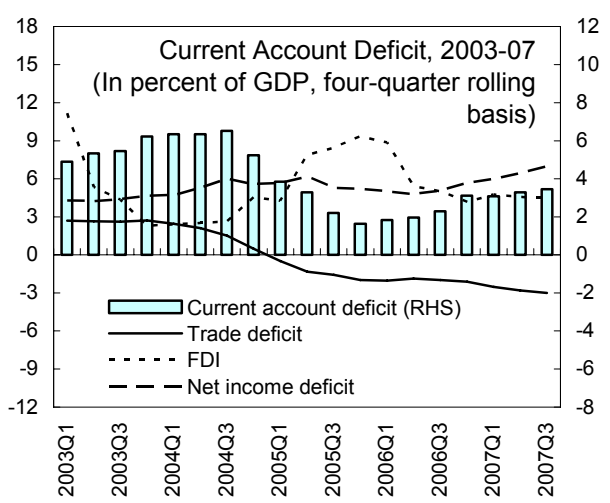

Source: Czech Statistical Office; and Czech National Bank. 
6. Underlying inflation has picked up from the low levels of recent years. Core inflation, which had remained subdued at around 1 percent, has risen steadily since late 2006 , fuelled by higher domestic demand amid tightening labor markets, strong credit expansion, and rising food and regulated prices. The depreciation of the koruna during the first half of 2007, precipitated by the negative carry trade vis-àvis the euro area also added to inflation. Although the liquidation of these carry trades amid the global financial turmoil in August contributed to reversing the depreciation, strong consumption demand and rising food and oil prices pushed headline inflation to 5 percent in the year to November 2007, well above the upper margin of the Czech National Bank's (CNB) tolerance band of 1 percent around the target of 3 percent.
Strong domestic demand has fuelled a rise in core inflation.

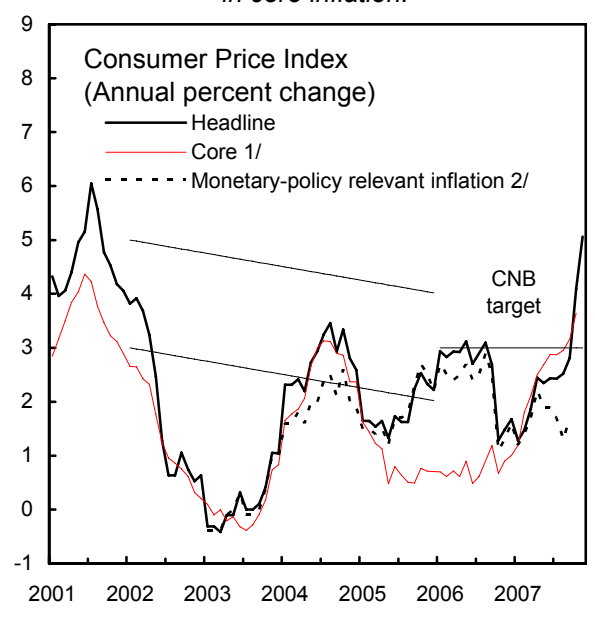

Sources: Czech Statistical Office; Eurostat; and IMF staff estimates.

1/ Harmonized CPI excluding energy and seasonal food.

2/ Adjusted for first-round impact of changes to indirect taxes.

\section{Consistent with the inflation targeting framework, monetary policy was} tightened in recent months to counter rising inflation pressures (Figure 4). Monetary conditions eased in early 2007 as the policy rate was kept unchanged, rising inflation lowered real interest rates, and the koruna depreciated. Against a backdrop of strong domestic demand and a widening of the interest rate differential vis-à-vis the euro area-already at 125 basis points in May 2007-the CNB raised its policy rate in steps from $2 \frac{1}{2}$ percent to 3 percent in early summer. Despite tightening credit conditions in European financial markets, the CNB raised the rate further to $3 \frac{1 / 4}{4}$ percent in August and to $3 \frac{1}{2}$ percent in November 2007. Although real rates have turned negative, the rapid appreciation of the koruna in recent months - about 5 percent since October - has contributed to tightening monetary conditions. The Czech policy rate remains among the lowest in the EU.

\section{Fiscal policy in $\mathbf{2 0 0 7}$ is expansionary even though strong growth has resulted in a}

\section{considerably more favorable} outturn than budgeted. Spurred

by the strength in household incomes, consumption and corporate profits, buoyant tax revenues are likely to keep the general government deficit (on ESA-95 basis) below 3 percent of GDP, fortuitously offsetting the large increase in social benefits stemming from pre-election com the fiscal stance for 2007 is nevertheless estimated to be expansionary, albeit modestly.

\begin{tabular}{lrrrr}
\multicolumn{5}{c}{ Fiscal Stance, ESA-95, 2005-07 (In percent of GDP) } \\
\hline & 2005 & 2006 & \multicolumn{2}{c}{2007} \\
\cline { 2 - 5 } & Actual & Actual & Auth Proj. & Staff Proj. \\
\cline { 2 - 5 } Revenue & 41.3 & 40.7 & 39.8 & 40.4 \\
Expenditure & 44.9 & 43.6 & 43.3 & 43.2 \\
General Government Deficit & -3.5 & -2.9 & -3.4 & -2.8 \\
& & & & \\
Cyclically Adjusted Deficit 1/ & -2.8 & -2.9 & -3.7 & -3.4 \\
Cyclically Adjusted Primary Deficit & -1.6 & -1.8 & -2.6 & -2.2 \\
Change (Fiscal Impulse) & 1.4 & 0.2 & 0.8 & 0.4 \\
& & & & \\
Memo: & & & & \\
Nominal GDP growth & 6.3 & 7.5 & & \\
General Government Debt & 30.2 & 30.1 & 30.4 & 29.5 \\
\hline Source: Ministry of Finance and staff estimates. & & & \\
1/ Assumes staff estimates of output gap. & & &
\end{tabular}


9. Near-term vulnerabilities are limited. Public debt remains relatively low at around 30 percent of GDP, with limited exposure to foreign currency debt. While external debt has risen to around 41 percent of GDP at end-2006, gross international reserves continued to rise
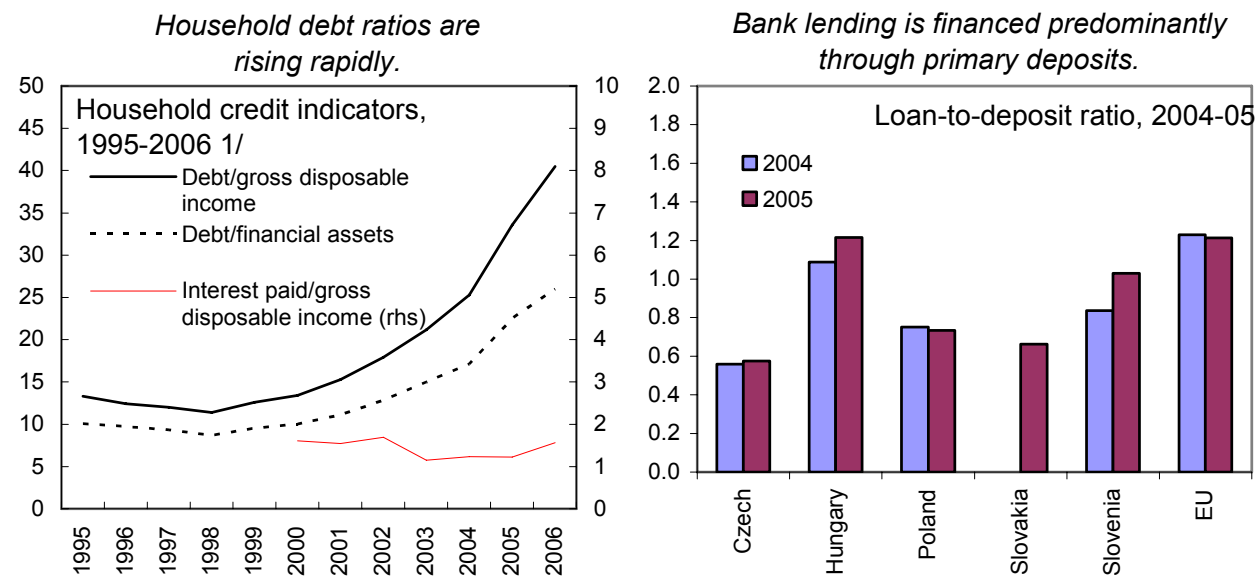

Source: Financial Stability Report, 2006; Czech National Bank.

1/ Data for 2005 and 2006 are only estimates.

as well, reaching above US\$ 31 billion by end-October, covering over 3 months of imports and 1.2 times short-term maturing debt (Table 4 ). While household debt-primarily mortgages - has risen rapidly, credit risks are limited by the low level of foreign currency borrowing, with bank lending financed primarily through domestic deposits.

\section{Investor sentiment remains positive, with almost no spillover from the global}

market turbulence. Liquidity conditions in the money markets have remained benign with

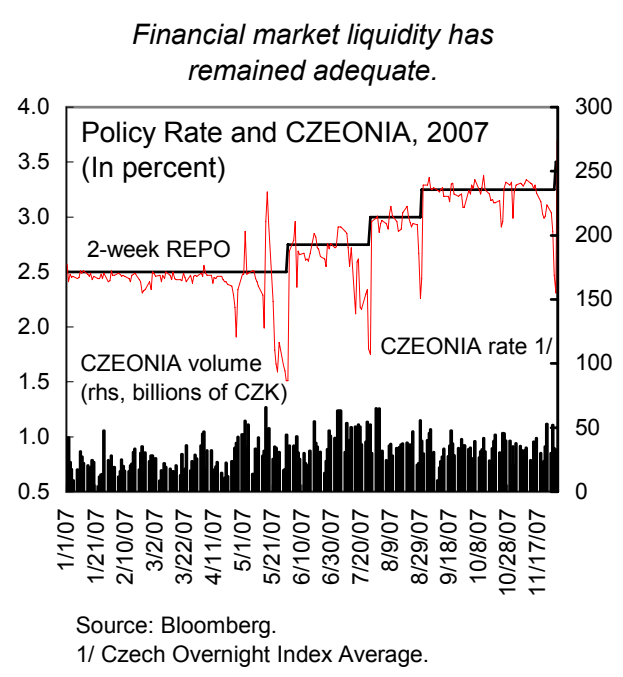

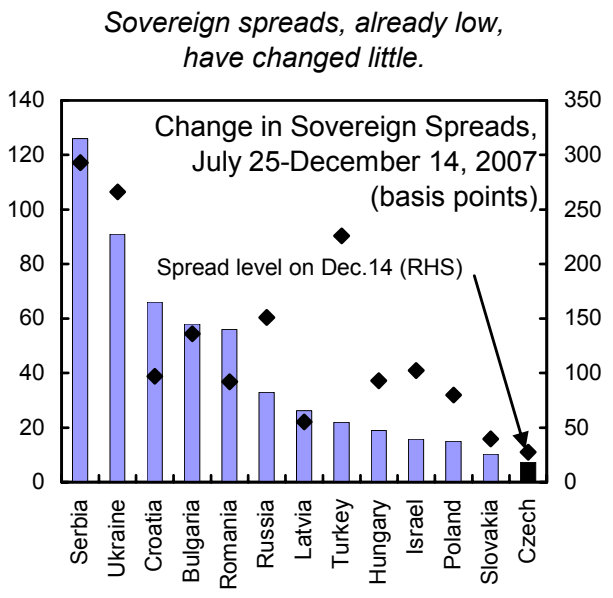

Source: Bloomberg; and IMF staff calculatios.

overnight rates moving in line with the policy rate. Sovereign spreads, already low, rose little during August-December 2007, reflecting limited reliance on cross-border bank loans and 
sound financial position of borrowers (Figures 5 and 6). Yields remain the lowest in Central Europe.

\section{ECONOMIC OUTLOOK}

\section{Economic growth is expected to slow in $\mathbf{2 0 0 8}$ but should remain solid on the} back of continued strong domestic demand. Staff projects growth to decline to about $4 \frac{1}{2}$ percent, in line with the consensus, as recent fiscal measures to raise VAT and reduce social benefits weigh on private consumption and growth in the euro area weakens. The planned tightening of the fiscal stance will also contribute to a dampening of domestic demand. On the other hand, fixed investment is projected to rise supported by strong corporate profits, tax cuts and the need for capacity expansion. Over the medium term, output is expected to be boosted by the coming on stream of a large export-oriented project in the automobile sector, ${ }^{3}$ boosting integration with domestic supplier chains Comparative Growth and Inflation Forecasts, 2007-09

\begin{tabular}{|c|c|c|c|}
\hline & 2007 & 2008 & 2009 \\
\hline \multicolumn{4}{|c|}{ Growth } \\
\hline IMF (November) & 5.9 & 4.6 & 5.2 \\
\hline Consensus (November) & 5.8 & 4.8 & 4.8 \\
\hline MOF (October) & 5.9 & 5.0 & 5.1 \\
\hline CNB (October) & 6.2 & 5.0 & 5.6 \\
\hline \multicolumn{4}{|c|}{ Inflation (annual average) } \\
\hline IMF & 3.0 & 5.4 & 3.5 \\
\hline Consensus & 2.7 & 4.5 & 3.1 \\
\hline MOF & 2.3 & 3.8 & 2.2 \\
\hline CNB & 2.4 & 4.9 & 3.5 \\
\hline
\end{tabular}

Sources: Consensus Forecasts, Czech authorities, (Table 5). Output is thus likely to remain and IMF staff estimates.

above its potential level and unemployment low.

Forward looking indicators suggest a slowdown but still robust growth.
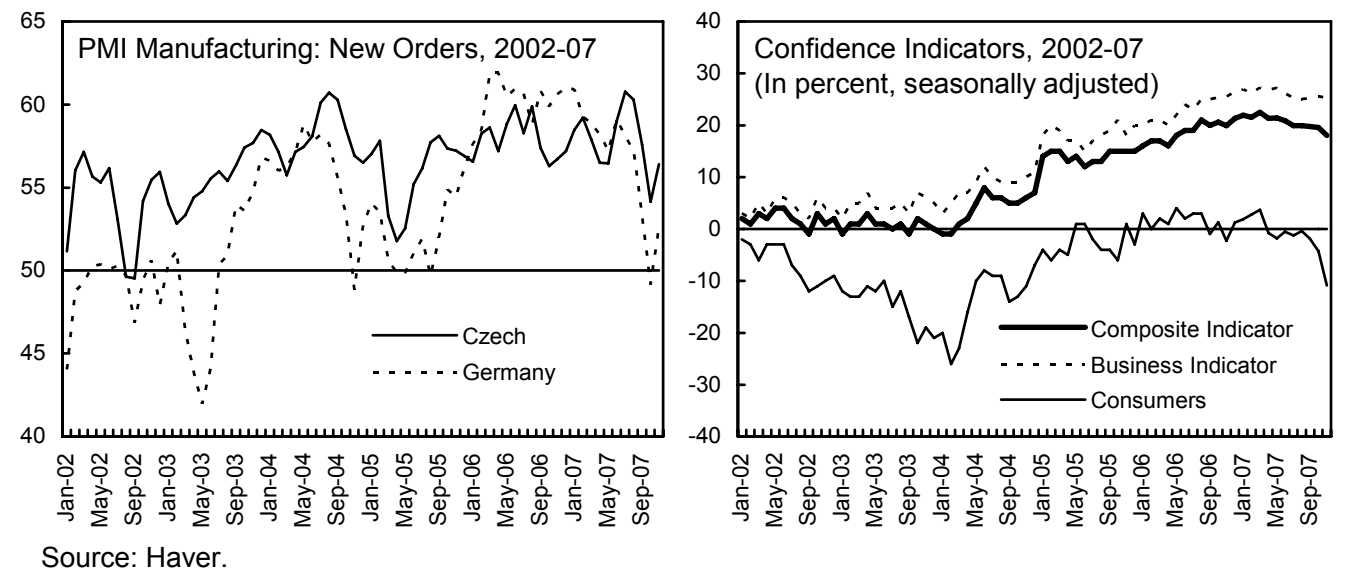

\footnotetext{
${ }^{3}$ Hyundai is expected to start a major new automobile plant in late 2008, which could contribute nearly a percentage point to GDP growth.
} 
Czech Republic: Macroeconomic Developments, 2006-10
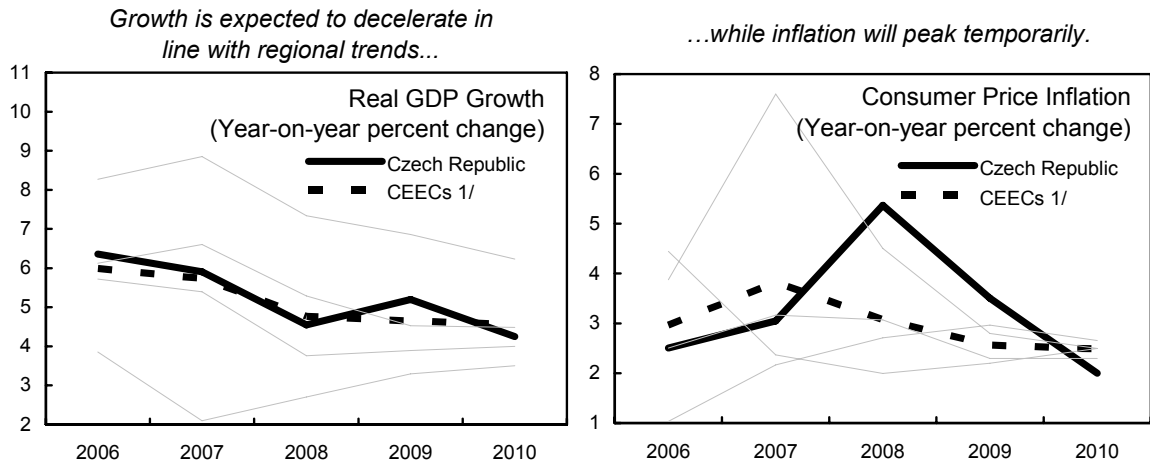

Sources: WEO; and IMF staff estimates.

1/ Average for Hungary, Poland, the Slovak Republic, and Slovenia.

12. The risks to this forecast are on the downside, stemming primarily from fragility of growth in major export markets. ${ }^{4}$ There is so far no discernible spillover through credit channels from the ongoing financial market turbulence abroad. However, if the turmoil were to persist leading to a more pronounced slowdown in the euro area and the United States, it could adversely affect Czech exports. Continued high oil prices could also place a further drag on growth. Labor supply constraints at home add to these risks. Despite these risks, stress tests suggest that external debt will remain stable over the medium term (Figure 7 and Table 6).

\section{Inflation is set to rise sharply against a backdrop of demand and wage pressures} as well as rising food and energy prices and increases in indirect taxes. Headline inflation is forecast to rise above 5 percent in 2008, well above the upper margin of the Czech National Bank's tolerance band around the target of 3 percent, mainly on account of the first round effects of increases in VAT and excises. Core inflation is also expected to rise in the face of a positive output gap and a tight labor market. Following a lengthy period of low inflation, there is a risk of such a rapid doubling of headline inflation feeding into inflation expectations with knock-on effects on wage and price setting. A slower pace of koruna appreciation could also remove a recent significant anti-inflationary influence, placing a greater burden on monetary policy.

\section{Medium-term growth prospects hinge on deeper structural reforms. Aging will} increase pressures on the public finances and the labor market. The tax-benefit system has created low-wage and unemployment traps. Labor supply constraints despite high long term unemployment, skill mismatches and sizable regional disparities point to low labor market flexibility, exacerbated by strict employment protection regulations (Figure 8). Rankings of business competitiveness have slipped, reflecting concerns regarding growing scarcity of skilled labor, slow judicial processes, and corruption. Rising wage pressures could erode

\footnotetext{
${ }^{4}$ The staff forecasts are being reassessed in the context of the ongoing World Economic Outlook round.
} 
competitiveness. Failure to address these structural weaknesses could adversely affect labor utilization and investment, reducing growth prospects in the face of intensifying regional competition. Against this background, staff projects potential growth to slow to around $4 \frac{1}{2}$ percent.

EU8: Business Competitiveness Rankings, 2007 (Change from last year)

\begin{tabular}{|c|c|c|c|c|c|c|c|}
\hline \multicolumn{2}{|c|}{$\begin{array}{l}\text { Heritage Foundation } \\
\text { Economic Freedom }\end{array}$} & \multicolumn{2}{|c|}{$\begin{array}{c}\text { IMD World Competitiveness } \\
\text { Scoreboard }\end{array}$} & \multicolumn{2}{|c|}{$\begin{array}{l}\text { WEF Global Competitiveness } \\
\text { Index }\end{array}$} & \multicolumn{2}{|c|}{$\begin{array}{l}\text { World Bank Doing Business } \\
\text { Index }\end{array}$} \\
\hline Estonia & $12(-5)$ & Estonia & $22(-3)$ & Estonia & $25(1)$ & Lithuania & $16(-1)$ \\
\hline Lithuania & $22(1)$ & Lithuania & 31 & Czech Republic & $29(0)$ & Estonia & $17(0)$ \\
\hline Czech Republic & $31(-10)$ & Czech Republic & $32(-4)$ & Slovenia & $33(-3)$ & Latvia & $24(7)$ \\
\hline Slovakia & $40(-5)$ & Slovakia & $34(-1)$ & Latvia & $36(3)$ & Slovakia & $36(-2)$ \\
\hline Latvia & $41(-2)$ & Hungary & $35(0)$ & Slovakia & $37(-1)$ & Czech Republic & $52(-2)$ \\
\hline Hungary & $44(-4)$ & Slovenia & $40(-1)$ & Lithuania & $40(-6)$ & Slovenia & $61(-5)$ \\
\hline Slovenia & $58(-20)$ & Poland & $52(-2)$ & Hungary & $41(-6)$ & Hungary & $66(-6)$ \\
\hline Poland & $87(-26)$ & Latvia & n.a. & Poland & $48(-5)$ & Poland & $75(-1)$ \\
\hline
\end{tabular}

Sources: Heritage Foundation, IMD, World Economic Forum, World Bank.

\section{Policy discussions}

\section{The central theme of the discussions was the imperative of strong fiscal} consolidation as a prerequisite to ensuring smooth euro entry and sustained long-term growth with external stability. Although the longer-term structural challenges formed the backdrop for the fiscal reform strategy, the consultation centered on three key topics seen as pivotal to sustained and balanced growth:

- $\quad$ the need for a restrictive policy stance in 2008 , in view of a still positive output gap and rising inflation pressures, with an appropriate mix between fiscal and monetary policy;

- $\quad$ implications of the recently adopted fiscal package, and the importance of setting clear priorities between competing objectives of fiscal consolidation and tax relief;

- $\quad$ the need for vigilance over the financial sector in the current uncertain market environment.

\section{A. Ensuring Sustainable Public Finances}

16. Durable fiscal reform remains the primary policy challenge. Seeking to reverse the trend toward fiscal relaxation afforded by the gains from the economic upswing, the authorities recently unveiled a tax and welfare reform package (Box 1). It aims to reduce excessive deficits ${ }^{5}$ and stabilize the medium-term budget while lowering the tax burden. The authorities plan to reduce the deficit from the officially projected 3.4 percent of GDP in 2007 to 2.9 percent in 2008. They plan to further lower the deficit to 2.3 percent of GDP by 2010, entailing a cumulative fiscal effort of about $1 \frac{1}{2}$ percent of GDP over the next three years. However, they acknowledge that underlying expenditure measures to achieve these goals are

\footnotetext{
${ }^{5}$ The Czech Republic has remained under the Excessive Deficit Procedure of the EU since 2004.
} 
yet to be fully spelled out and pressure from the coalition partners for further tax cuts remain. Although public debt remains low and stable (Figure 9 and Table 7) owing to the favorable growth and financing from privatization revenues, the authorities recognize the crucial role of expenditure consolidation to address challenges created by a rapidly aging population.

\section{Box 1. The Tax and Welfare Reform Package: Key Measures}

The recently adopted tax and welfare reform package seeks to strengthen government finances, lower the tax burden while also promoting growth and employment. Key measures include:

\begin{tabular}{|lrrr|}
\hline & \multicolumn{3}{c|}{$\begin{array}{c}\text { Impact on Fiscal Balance } \\
\text { (In percent of GDP) }\end{array}$} \\
& 2008 & 2009 & 2010 \\
\hline $\begin{array}{l}\text { Introduction of a flat rate of personal income tax at 15 percent (while } \\
\text { broadening the tax base to include social security contributions and } \\
\text { increasing tax credits) }\end{array}$ & -0.6 & -0.7 & -0.8 \\
$\begin{array}{l}\text { Phased reduction of corporate income tax from the current 24 percent to } \\
19 \text { percent by 2010 }\end{array}$ & -0.2 & -0.6 & -0.8 \\
& & & \\
Increase in the lower VAT rate from 5 percent to 9 percent and & 1.0 & 1.0 & 0.9 \\
introduction of environmental taxes & & & \\
Introduction of a ceiling on social security contributions & -0.2 & -0.2 & -0.2 \\
Reduction and streamlining of social benefits, and health care reform 1/ & 0.5 & 0.7 & 0.6 \\
\hline Total & 0.6 & 0.2 & -0.2 \\
\hline
\end{tabular}

Source: Czech Ministry of Finance.

1/ Adjusted to exclude measures not yet approved (health care in 2010) and savings due to postponement of measures (casualty and sickness insurance).

An analysis of the fiscal reform package suggests some desirable features. ${ }^{1}$ The Czech tax system currently relies heavily on social security contributions and corporate income taxes. A shift in the tax structure away from direct towards indirect taxes will likely contribute to enhanced savings and investment.

However, the package does not fully deliver on its objectives in an efficient and cost-effective way. The personal income tax cuts are largely unnecessary and not well-targeted. The substantial disincentives to work at low wages - as shown by the marginal tax

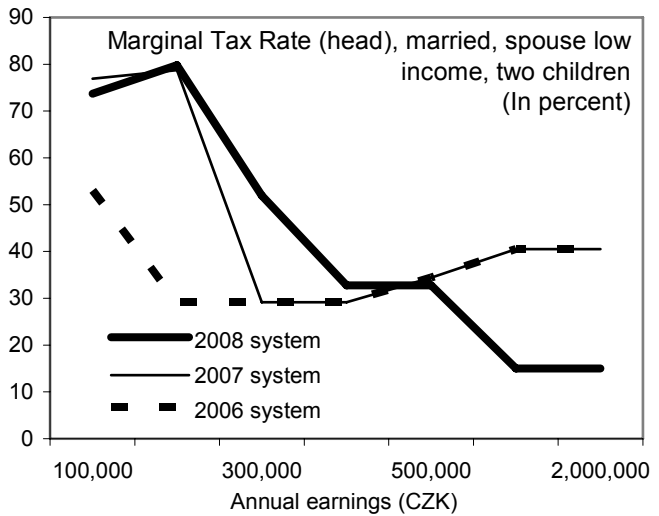
rates caused by the combined effects of income tax, social security contributions and withdrawal of benefits-have not been effectively addressed (text chart). The cap on social security contributions would also reduce revenue efficiency.

Furthermore, the package does not address the critical task of fiscal consolidation in the medium- to longterm since the permanent tax cuts are offset by spending measures which are of a temporary nature or yet to be defined.

\footnotetext{
${ }^{1}$ For further details, see accompanying background paper on Tax and Welfare Reform in the Czech RepublicStructural Implications and Challenges.
} 


\section{Against this backdrop, staff argued for saving any cyclical gains for the $\mathbf{2 0 0 8}$}

budget. The authorities agreed that the 2007 outturn was likely to be better than the projected 3.4 percent of GDP, absent one-off or large end-of-year spending - by over $1 / 2$ percent of GDP in staff's estimates. Based on a more favorable 2007 deficit estimate, staff argued that the fiscal effort envisaged in the already approved budget, would imply a

Fiscal Outlook, ESA-95, 2006-10 (In percent of GDP)

\begin{tabular}{lrrrrrr}
\hline & 2006 & & 2007 & 2008 & 2009 & 2010 \\
\cline { 4 - 7 } & Actual & & \multicolumn{5}{c}{ Staff Projections } \\
\cline { 2 - 6 } \cline { 5 - 7 } General Government Deficit & -2.9 & & -2.8 & -2.2 & -2.1 & -2.5 \\
Cyclically Adjusted Deficit & -2.9 & & -3.4 & -2.9 & -3.0 & -3.3 \\
Cyclically Adjusted Primary Deficit & -1.8 & -2.2 & -1.6 & -1.8 & -2.1 \\
Change (Fiscal Impulse) & 0.2 & & 0.4 & -0.6 & 0.2 & 0.3 \\
Memo: & & & & & \\
General Government Debt & 30.1 & 29.5 & 28.9 & 28.4 & 28.5 \\
\hline
\end{tabular}

Source: Ministry of Finance and staff estimates. commensurately lower deficit target, of around 21/4 percent of GDP, in 2008. Attaining this target would require that additional discretionary spending - from accumulated reserves of prior years - does not offset this adjustment; automatic stabilizers should however be allowed to play around this path. This adjustment was deemed appropriate given the still positive output gap and risks to achieving the planned consolidation in 2009-10.

\section{The authorities concur that fiscal consolidation, centered on pension and health care reforms, needs to be sustained beyond 2008, although political constraints could} limit its scope. The authorities' Convergence Program plans an annual consolidation of around $1 / 2$ percent of GDP in structural terms and a medium term deficit objective of 1 percent of GDP by 2012 to meet the SGP requirements and accommodate age-related spending pressures. Staff stressed that the Czech Republic remains one of the few countries that has yet to start reforming its pension system despite having one of the largest fiscal gaps that need to be filled. In the absence of comprehensive pensions and health care reforms, the medium-term objective would not ensure sustainable public finances. ${ }^{6}$ Officials noted that despite recent progress, political

Sustainability Gap Indicators (percent of GDP) 1/

\begin{tabular}{|c|c|c|c|}
\hline & $\begin{array}{l}\text { Change in Age- } \\
\text { related } \\
\text { Expenditures, } \\
2005-50\end{array}$ & $\mathrm{~S} 1$ & S2 21 \\
\hline Czech Republic & 7.7 & 2.5 & 5.5 \\
\hline Hungary & 7.1 & 7.9 & 9.8 \\
\hline Slovenia & 9.9 & 3.9 & 7.3 \\
\hline Poland & -3.2 & -0.4 & -0.2 \\
\hline Slovakia & 3.7 & 1.3 & 3.0 \\
\hline EU25 & 4.1 & 2.1 & 3.4 \\
\hline
\end{tabular}

Source: Long Term Sustainability of Public Finances in the EU, 2006.

$1 / \mathrm{S} 1$ measures the change in primary balance needed to keep debt below 60 percent in 2050 .

2/ S2 measures the change in primary balance needed to meet the intertemporal budget constraint. constraints remained.

\section{The authorities stressed that the fiscal package represented a delicate} compromise within the governing coalition. The tax reform proposals, although revenue neutral in 2008, will lead to a loss of revenues in 2009 and beyond. Officials also acknowledged that the expenditure measures only slow down rather than arrest the current rapid pace of growth in mandatory spending. Significant risk remains that measures such as compression of public sector wages and the freezing of social benefits will not be

\footnotetext{
${ }^{6}$ See accompanying background paper on Tax and Pension Reform - Implications for Growth and Debt Sustainability
} 
sustainable. In their view, the package contained positive features such as greater discretionary scope in the budget through deindexation of social benefits and improved targeting of some parental and child benefits. Staff noted that these measures nevertheless did not fully claw back the large social spending approved ahead of the 2006 elections.

\section{Looking ahead, the fiscal strategy needs to (i) strike a balance between spending} and revenue measures; (ii) achieve systemic reforms in pensions and healthcare; and (iii) promote complementary reforms in the labor market.

- The authorities agreed that spending measures are a priority not only to achieve the needed consolidation but also to enhance efficiency and budgetary flexibility. Staff cautioned that without durable offsetting expenditure measures, the Czech Republic cannot afford the planned tax cuts and may even have to consider tax increases.

- On pension reform, political consensus has been reached on raising the retirement age to 65 years, but since it is unlikely to restore pension system viability, creation of pension reserves to ensure greater intergenerational equity is being planned. Increased reliance on private pension savings, including through a partial voluntary opt-out is also being considered. In health care, the introduction of co-payments has marked an important step towards containing excess demand pressures. Further efforts to contain costs and reduce distortions in the system are being debated by the political parties.

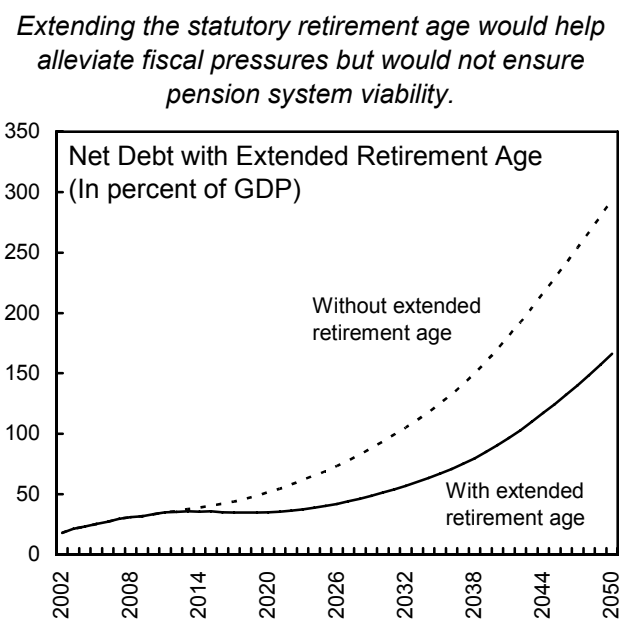

Source: IMF staff calculations.

- The officials were receptive to the staff's view that labor market reform to lower structural unemployment and tax-benefit reform to reduce disincentives to work can ease fiscal adjustment. However, they were not optimistic on the near-term prospects of changes to the employment protection regulations, following closely on the heels of the new labor code passed in 2006.

\section{B. Monetary Policy Conduct and Communication}

\section{With inflation projected to be above target, monetary policy would need to} remain on a sustained path of tightening. $\mathrm{CNB}$ officials noted that in deciding the precise pace of tightening in the face of the projected sharp rise in inflation, they will need to weigh factors such as the developments in the koruna, recent evidence of weaker European growth and the stance of fiscal policy. ${ }^{7}$ While recent wage negotiations suggest continued wage

\footnotetext{
${ }^{7}$ See accompanying background paper on Challenges to Monetary Policy.
} 
moderation, the behavior of the exchange rate, driven in recent months largely by movements in the U.S. dollar, could complicate monetary management (Box 2). Inflation expectations pose another significant source of uncertainty. They further noted that in the recent period of low inflation since 2004, the inflation process had exhibited considerable persistence, easing the task of monetary policy. With a series of upward shocks to inflation in the period ahead, against a backdrop of tightening labor market conditions, staff and CNB officials agreed that it was important to ensure that expectations remained well anchored to the inflation target through timely policy tightening.

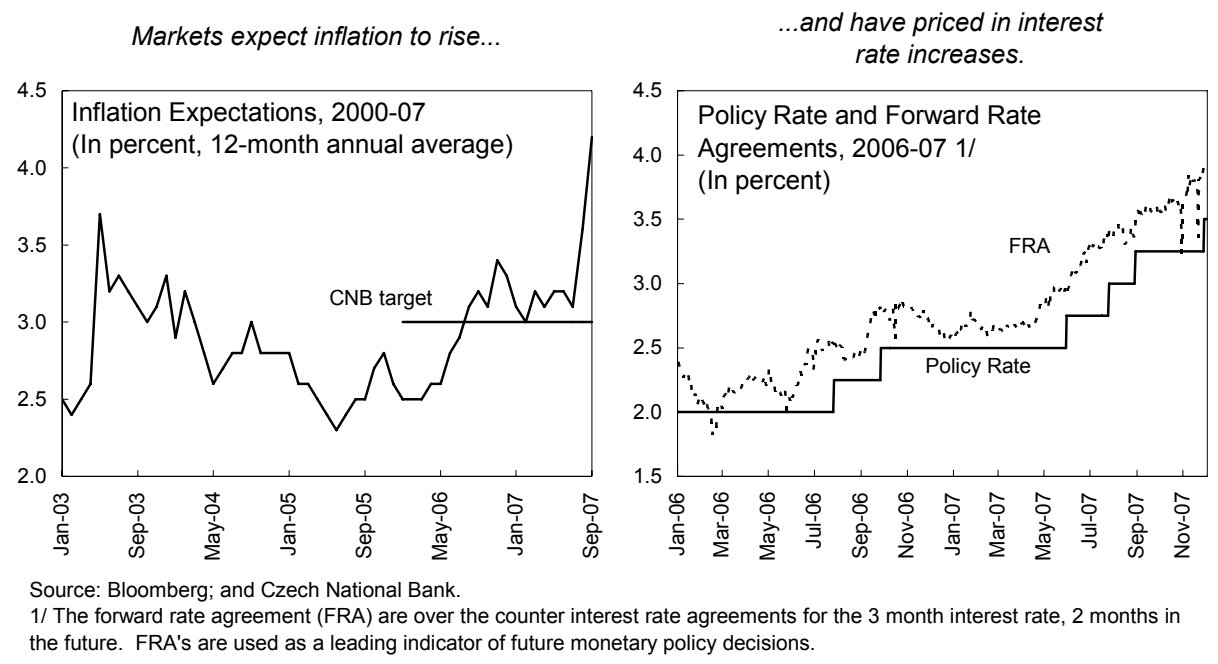

22. The planned downward shift in the inflation target to 2 percent from 2010 further underscores the importance of preserving credibility and enhancing transparency of policy communication. The decision to lower the target is based on the assessment that low inflation has taken firm roots in the Czech economy and that any real appreciation in the remaining process of convergence would continue to manifest itself through koruna appreciation rather than higher inflation. With the onset of a spike in headline inflation reflecting a number of one-off shocks, shaping expectations was critical in achieving the target with minimal output losses. In this context, officials felt that the recent decision to publish a forecast-consistent interest-rate path and make public the voting records of the Executive Board meetings, beginning in 2008, should enhance transparency and policy credibility and smooth the transition to a lower inflation target. 


\section{Box 2. Is the Czech Koruna Funding Carry Trades?}

The use of the Czech koruna as a funding currency for carry trades has been an important driver of the exchange rate movements in 2007. Low interest rates and exchange rate volatility, and increasing liquidity in local foreign exchange markets made the koruna an attractive currency for carry trades leading to a depreciation by more than 4 percent during the first half of 2007. The main instruments for these transactions comprised of financial derivatives - primarily outright forwards and currency swapswhich showed two spikes in January and June 2007 preceding the net outflows from July 2007 (text chart). Hedge funds based in London and New York were the main participants reportedly trading the koruna for Turkish lira, Hungarian forint, and Polish zloty.

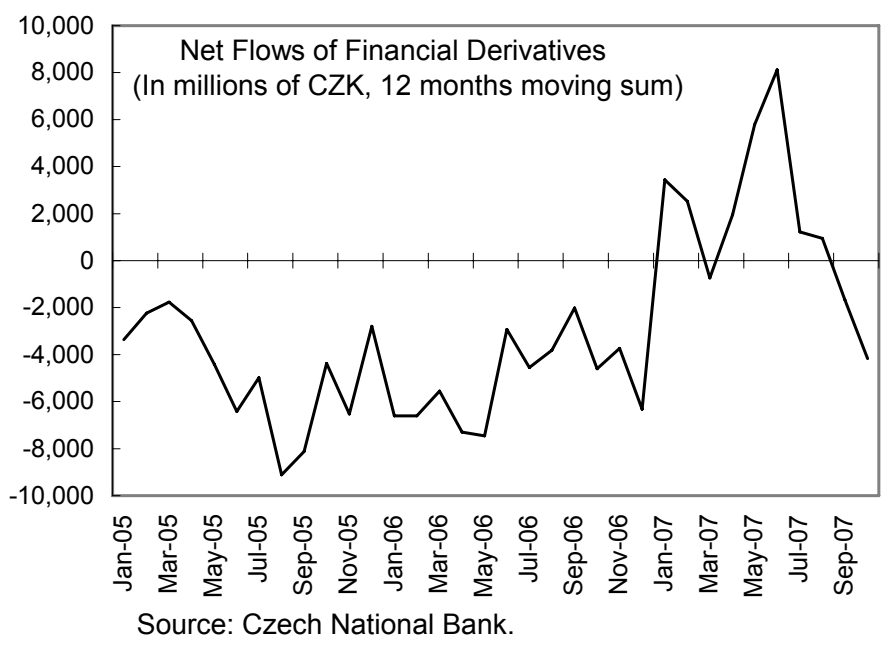

The appetite for carry trade using koruna as a funding currency has since disappeared. The subsequent monetary tightening initiated the first round of carry-trade unwinding, while the risk reassessment following the global financial market turmoil further accelerated the liquidation of carry-

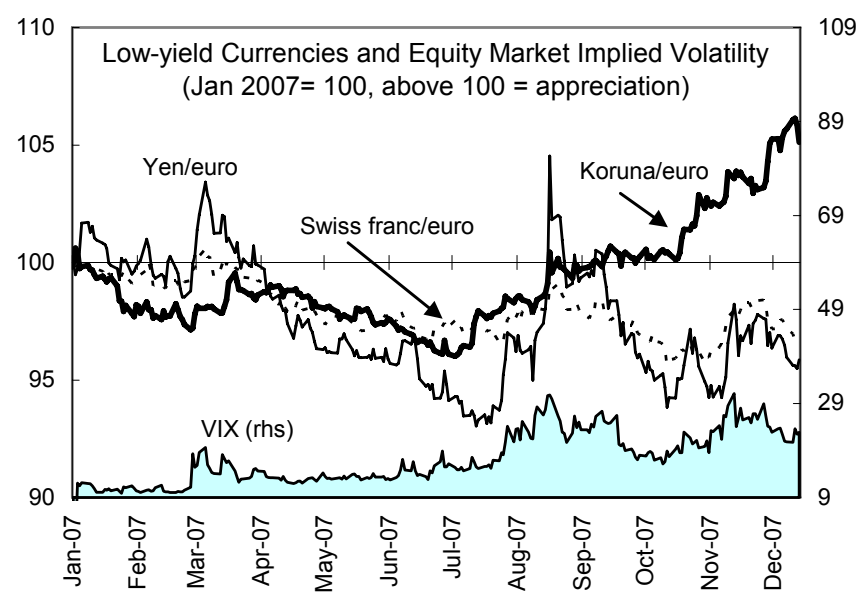
trade positions. The Czech koruna has visibly decoupled from other lowyield currencies and is again moving with CEE-4 currencies (text chart). The recent appreciation could also be driven by the weakening of the US dollar which seems to have led to a withdrawal of funds from U.S. assets to be invested in economies that are closely integrated with the euro areayielding extra profits on the appreciation of these currencies against the euro.

Source: Bloomberg L.P.; and IMF staff estimates.

\section{Competitiveness and External Stability}

23. The staff and the authorities agreed that the koruna had remained broadly in line with fundamentals, with limited risks to external stability. The real effective exchange rate, measured by consumer prices as well as by unit labor costs, has been broadly stable over the past year (Figures 10 and 11). Staff estimates the underlying current account deficit (excluding temporary factors such as cyclical fluctuations, one-off shocks, and adjustment lags) in 2007 at around 3 percent of GDP, slightly below the expected deficit and 
in line with its estimated equilibrium level. These estimates imply that the koruna has been close to its equilibrium level. ${ }^{8}$ Since the consultation discussions, the koruna has appreciated by about 5 percent against the euro by mid-December. Trade performance has remained robust, with double-digit growth in exports volume, rising export market shares in both the EU and world markets, and strong profitability of large exporters. Net foreign liabilities, mostly FDI, account for 30 percent of GDP and are projected to remain broadly stable. Since 2003, intervention has been limited to conversion of a large one-off privatization receipt in 2005, portfolio gains, and proceeds of EU transfers. CNB officials stressed that the koruna is floating independently since intervention was not intended to influence the exchange rate. In view of the large, albeit off-market, transactions, the exchange system is classified by the staff as a managed float with no predetermined path (see informational annex).
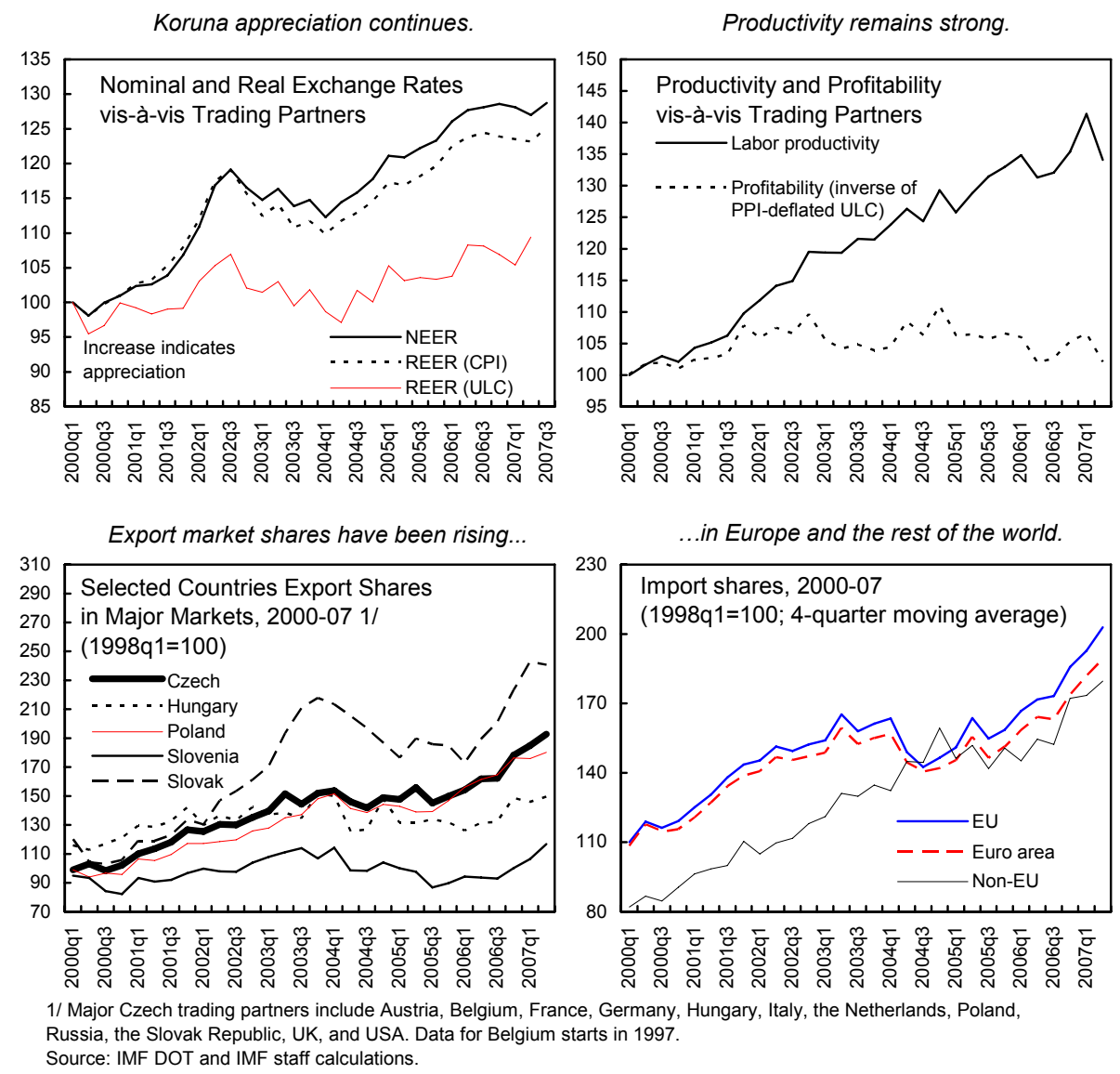

\section{The authorities have not announced a specific target date for euro adoption, pending more progress on fiscal consolidation and economic alignment with the euro} area. They continue to strive to meet the Maastricht criteria for euro entry in a sustainable

\footnotetext{
${ }^{8}$ Staff estimates of the equilibrium current account deficit are around 21/2 percent of GDP. Mid-December 2007 CGER estimates suggest that the real effective exchange rate, while on the strong side, is not appreciably out of line with underlying fundamentals. For an illustration of these concepts, see IMF Occasional Paper No. 167.
} 
manner. The CNB's decision to reduce the inflation target to 2 percent from 2010 will align it with the ECB's inflation target. Staff reiterated that euro adoption remains an important opportunity for reaping further gains from enhanced trade and investment opportunities and would serve as an important anchor for policy credibility, especially under more adverse economic conditions.

\section{Maintaining Financial Stability}

25. Credit growth has continued at a brisk pace, led by credit to households. Credit to the private sector increased by 25 percent in the year to September 2007, in line with regional trends. High demand for mortgage loans, supported by the low interest environment, a VAT hike in the construction sector in 2008 and increasing household repayment capacity contributed significantly to sustained household credit growth of around 30 percent. Enterprise credit has also accelerated with rising demand to finance expansion, including by property developers. Despite the rapid growth of house prices and rising interest rates, credit risk related to the household sector is currently low, given that most of the loans are denominated in domestic currency and on fixed interest rates terms. Moreover, the credit-to-GDP ratio remains relatively low by regional standards.

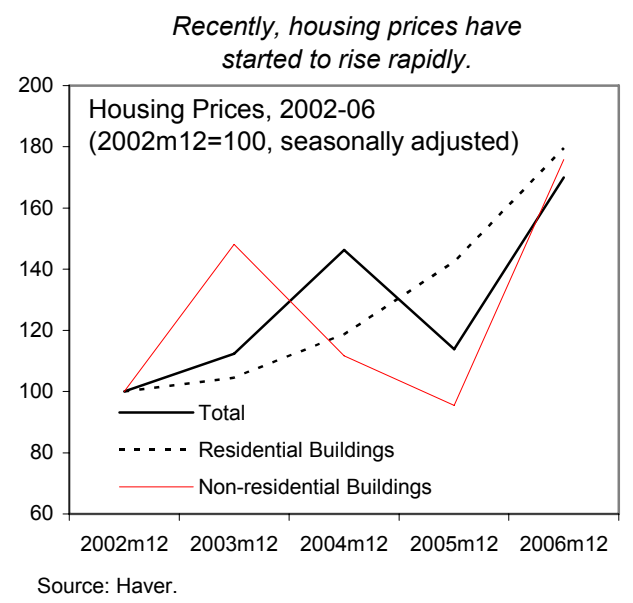

Bank Credit to Households and Non-financial Corporations in

European Emerging Markets, 2006
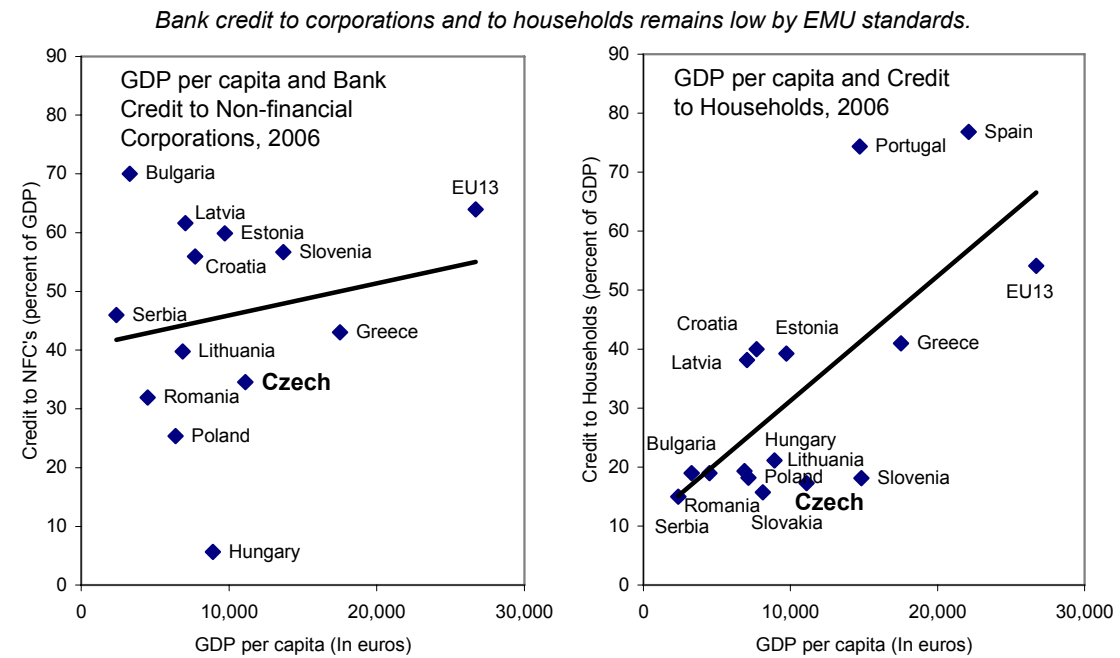

Source: Eurostat; ECB; Country Authorities; and IMF staff calculations. 
26. Financial stability indicators suggest that risks are contained. The Czech markets have remained largely unscathed by the recent turmoil, reflecting limited reliance on cross-border bank borrowing and virtual absence of securitization. Capital adequacy ratios have remained comfortably above the minimum regulatory thresholds despite a slight decline in 2005-06 reflecting rapid asset growth and record-high dividends. Bank profitability also

Financial Sector Indicators, 2003-07

\begin{tabular}{|c|c|c|c|c|c|}
\hline & 2003 & 2004 & 2005 & 2006 & $2007 q 3$ \\
\hline $\begin{array}{l}\text { Number of banks } \\
\text { Of which: foreign-controlled }\end{array}$ & $\begin{array}{l}35 \\
26\end{array}$ & $\begin{array}{l}35 \\
26\end{array}$ & $\begin{array}{l}36 \\
27\end{array}$ & $\begin{array}{l}37 \\
28\end{array}$ & $\begin{array}{l}38 \\
30\end{array}$ \\
\hline Regulatory capital to risk-weighted assets (in percent) & 14.5 & 12.6 & 11.9 & 11.4 & 11.9 \\
\hline Nonperforming loans (in percent of total loans) & 4.9 & 4.1 & 4.3 & 3.6 & 3.0 \\
\hline Liquid assets (in percent of total assets) & 36.4 & 33.6 & 32.8 & 30.4 & 28.6 \\
\hline After-tax return on average assets (in percent) & 1.2 & 1.3 & 1.4 & 1.2 & 1.3 \\
\hline
\end{tabular}

Sources: CNB; and IMF staff calculations.

remains healthy. Non-performing loan ratios, although lagging indicators, have been broadly stable and loan-to-value ratios indicate that banks are well collateralized. Sensitivity and stress test results, albeit limited to only the first-round impact of shocks, indicate that banks would be able to withstand the risk of sizeable defaults without jeopardizing capital positions.

\section{The authorities plan to further integrate supervisory functions to strengthen}

efficiency. With the introduction of unified supervision in 2006, the CNB took an important step to guard against contagion risk within pension and insurance markets. From 2008, the CNB will enhance integration by changing its supervisory organization from a sectoral model (banking, insurance, and securities) to a functional model (supervision, licensing and sanctions, regulation and analysis). Continued coordination of supervisory responsibilities with foreign (home country) supervisors will be important given the predominant foreign control of banks ${ }^{9}$ and the expected implementation of Basel II and the Markets in Financial Instruments Directive in 2008.

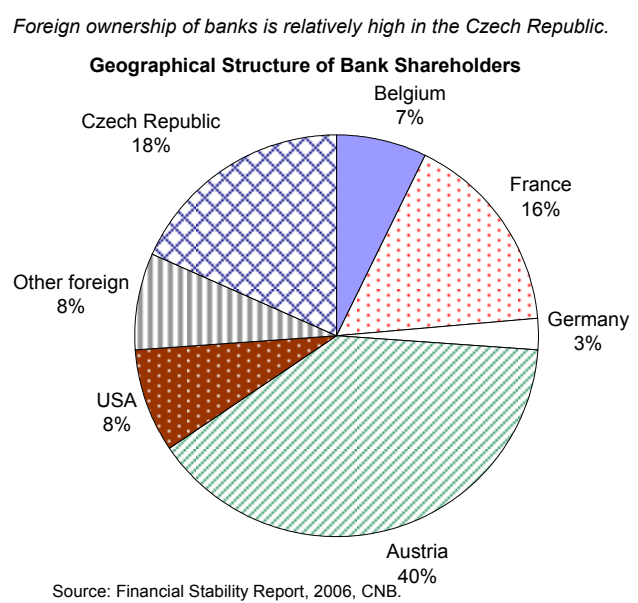

\footnotetext{
${ }^{9}$ Foreign bank branches, all operating under the single European license, accounted for 9.3 percent of total bank assets at end-2006.
} 


\section{Staff ApPraisal}

28. Over the past year, the Czech economy has maintained the momentum of rapid growth and made further strides toward convergence with the EU-15. However, sustaining this success through a less benign global environment and tighter supply constraints at home calls for a tight policy stance. Over the medium term, ensuring sustainable public finances would call for a higher political priority for pensions, healthcare and labor market reforms.

29. The economy is currently at a fairly advanced stage of a strong cyclical upswing and a slowdown in growth is likely in 2008. Growth is nevertheless expected to remain solid on the back of continued strong domestic demand and unemployment low. The risk to this central forecast is mainly on the downside, stemming primarily from a possibly weaker external environment.

30. With inflation set to rise sharply well above the target of 3 percent, monetary policy would need to be on a sustained tightening path. The projected increase in inflation to 5 percent in 2008 is driven by demand and wage pressures as well as rising food and energy prices and increases in indirect taxes. Following a lengthy period of low inflation, the risk that a rapid rise in inflation gets embedded into expectations will require further timely increases in the policy rate. The planned downward shift in the inflation target to 2 percent from 2010 onwards also underlines the importance of preserving the CNB's high policy credibility, inter alia, by enhancing the clarity of policy communication. In this context, recent steps to improve transparency are welcome.

\section{The external competitive position remains comfortable and vulnerabilities}

limited. The favorable indicators include a stable real effective exchange rate over the past year, robust export performance with rising export market shares and a moderate current account deficit, financed by direct investment inflows. These indicators suggest that the koruna has been broadly in line with fundamentals and consistent with external stability, although the recent sharp appreciation, if continued, would weigh on competitiveness.

32. Financial stability indicators suggest that risks are contained. Limited exposure to foreign markets and strong fundamentals have helped insulate the financial sector from the recent turmoil. Nevertheless, in an environment of rising interest rates and house prices, supervisory vigilance is needed to ensure that household credit risks do not build up, particularly for low-income borrowers.

\section{The tax and welfare reform recently passed by Parliament promotes a number} of desirable modifications to the structure of the tax regime. These include the shift from taxation of income to that of consumption, the introduction of excises on energy consumption and the planned cut in the corporate income tax rate which will help maintain the attractiveness of Czech Republic as an investment location. However, given the advanced 
cyclical position of the economy and the need to strengthen public finances, the tax cut could have been phased in more gradually.

34. The fiscal reform package is, however, insufficient to advance the critical task of fiscal consolidation in the medium term. Indeed, the package is likely to add to long-term fiscal pressures since the proposed tax cuts are permanent and well-defined, while some of the offsetting spending measures are of a temporary character and as yet undefined.

\section{Against the backdrop of the recent procyclical fiscal stance, cyclical gains for} the 2008 budget should be saved and the planned fiscal adjustment implemented in full. A more ambitious deficit target than that implied by the budget should be feasible in view of the favorable outcome in 2007. Such prudence in 2008 is all the more advisable in view of the absence of specific expenditure measures underlying the planned fiscal adjustment in 2009-10. With a tightening monetary policy cycle underway and the need to anchor inflation expectations, a tight fiscal stance is also essential to ensuring a balanced policy mix.

\section{Fiscal consolidation needs to be sustained beyond 2008 to meet the challenges} posed by the aging population and to ensure smooth euro entry. An annual structural consolidation of at least $1 / 2$ percent of GDP would help stabilize debt over the medium term and provide a safety margin in respecting the Stability and Growth Pact limit of 3 percent of GDP under more adverse cyclical conditions, and create fiscal space for accommodating agerelated spending. Recent changes in budgetary rules limiting rollover of unspent allocations should alleviate risks in attaining these budget targets.

\section{Durable fiscal consolidation calls for a strategy that sets clear fiscal priorities} with adequate balance between spending and revenue measures. Precedence should be given to expenditure rationalization. Absent expenditure restraint, tax cuts can be ill afforded and even tax increases may have to countenanced as part of a more sharply defined strategy to set fiscal priorities. Possible options include raising the low VAT rate further, reducing corporate loopholes, pruning personal tax credits, and increasing environmental taxes.

\section{Pension and healthcare reforms should clearly be key pillars of the medium-} term fiscal strategy. They should be implemented sooner rather than later, given the long lags with which especially pension reforms have their impact. Along with the welcome increase in the retirement age to 65 years, complementary reforms to raise the effective retirement age and reliance on private pensions will also be needed. In health care, the introduction of co-payments should help contain excess demand pressures and enhance efficiency of health care spending. Early consensus on more comprehensive reforms would be vital.

\section{Labor market reform can help alleviate fiscal adjustment. The recent fiscal} package fails to fully offset the adverse impact of the pre-election increase in social benefits on incentives to work. The substantially enhanced tax credits are not targeted and their effects on labor supply uncertain. Higher labor market participation and lower structural 
unemployment could be achieved through better targeted active labor market policies, less rigid regulations regarding hiring and dismissals, and an improved design of the tax-benefit system. More flexible labor markets would also help position the Czech economy for a smoother path to euro adoption.

40. It is proposed that the next Article IV consultation be held on the standard 12-month cycle. 
Figure 1. Czech Republic: Growth Developments, 2001-07 1/

(Annual percent change, unless indicated otherwise)

Economic growth has continued at a rapid

pace...

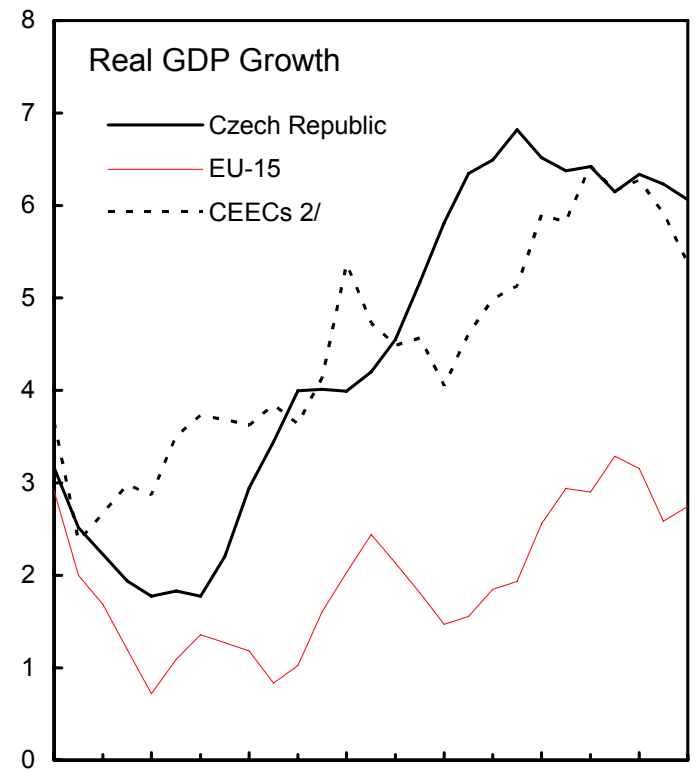

2001q1 2002q1 2003q1 2004q1 2005q1 2006q1 2007q1

Strong domestic demand is driven by rapid consumption growth..

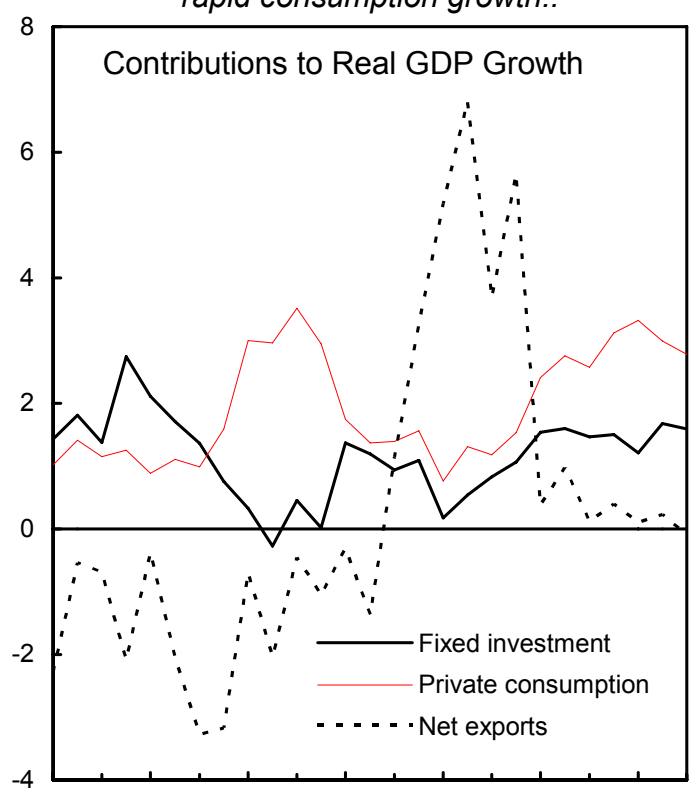

2001q1 2002q1 2003q1 2004q1 2005q1 2006q1 2007q1 ...but is expected to slow down.

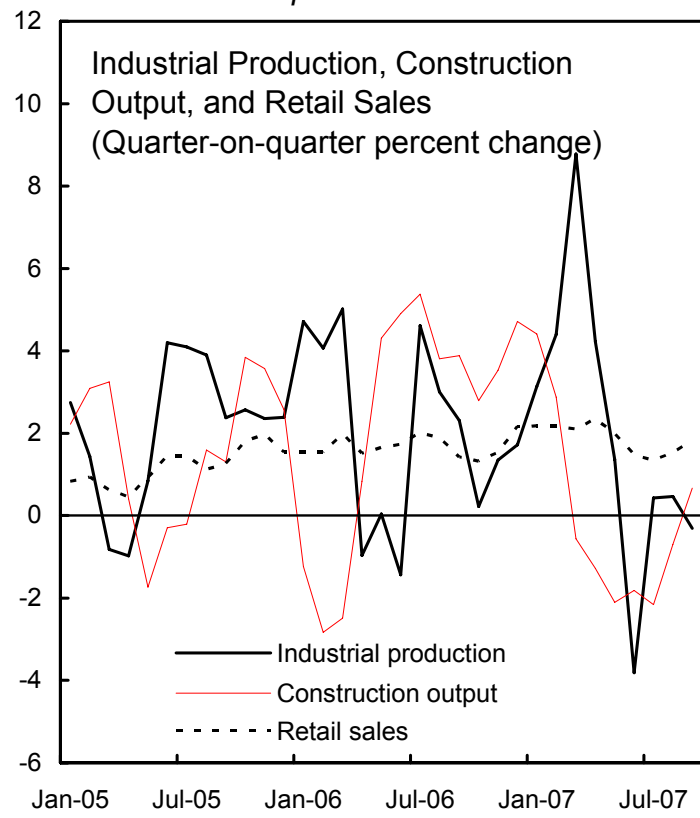

...and buoyant investment in machinery and equipment.

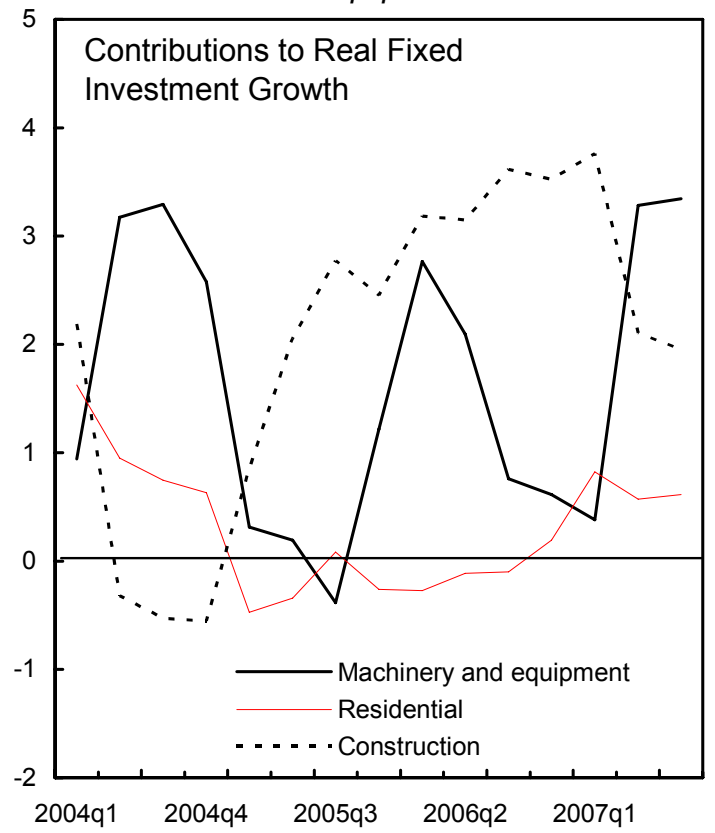

Sources: Czech Statistical Office; Eurostat; and IMF staff estimates.

1/ All series are seasonally adjusted.

2/ Average for Hungary, Poland, the Slovak Republic, and Slovenia. Excludes Slovenia in 2007q3. 
Figure 2. Czech Republic: Labor Market Indicators, 2000-07

Unemployment has declined...

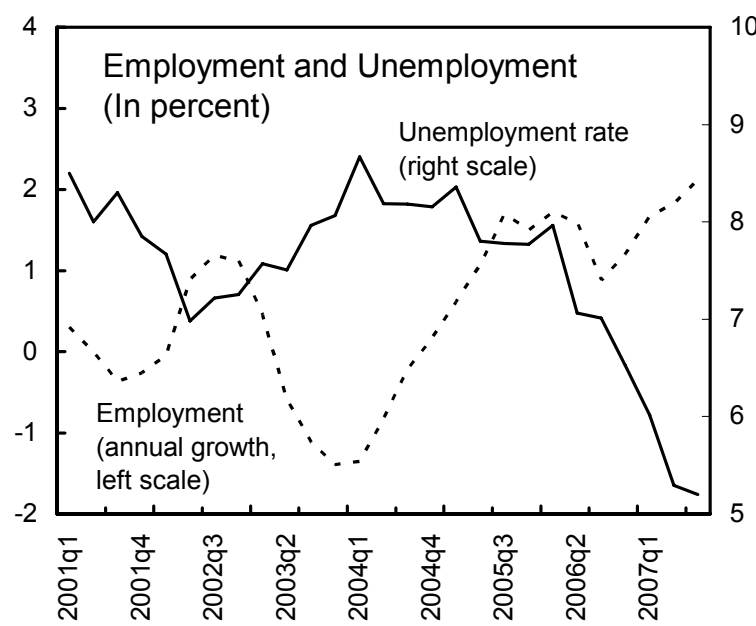

Signs of capacity constraints in the labor market...

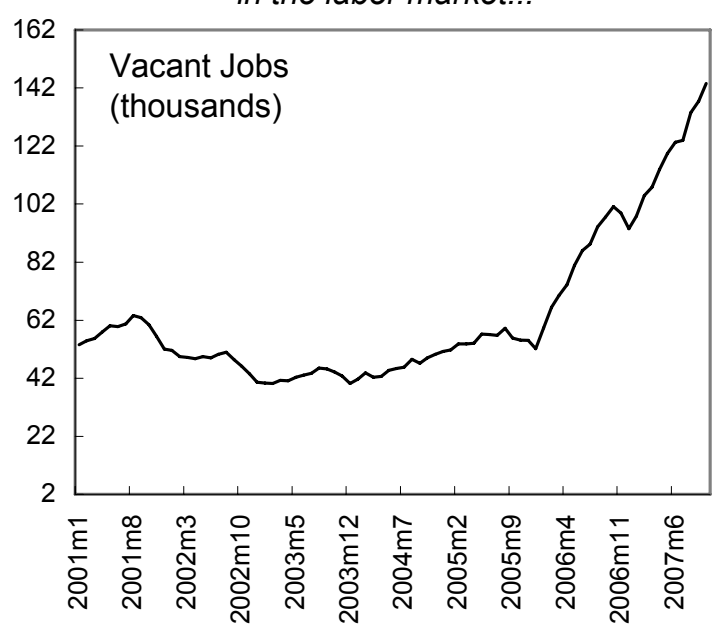

Despite some inward migration...

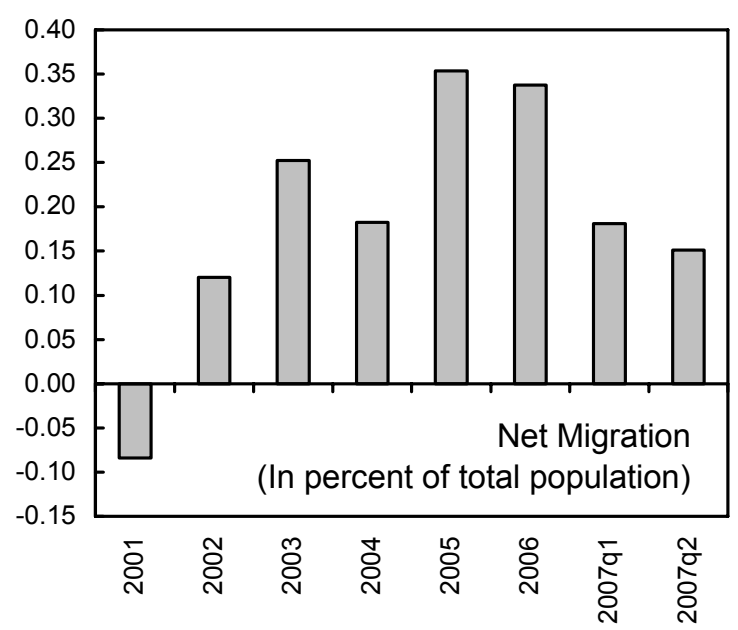

...in both cyclical and structural terms.

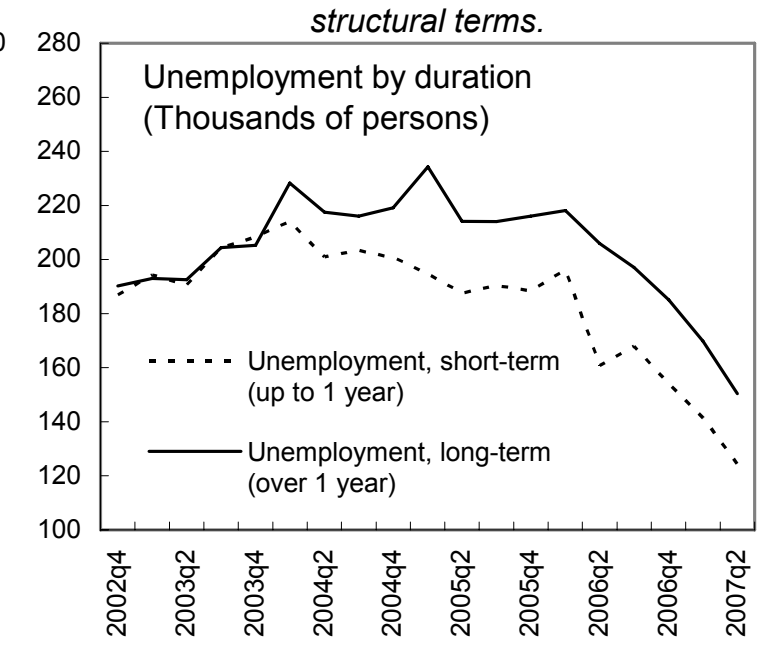

...and industry have emerged.

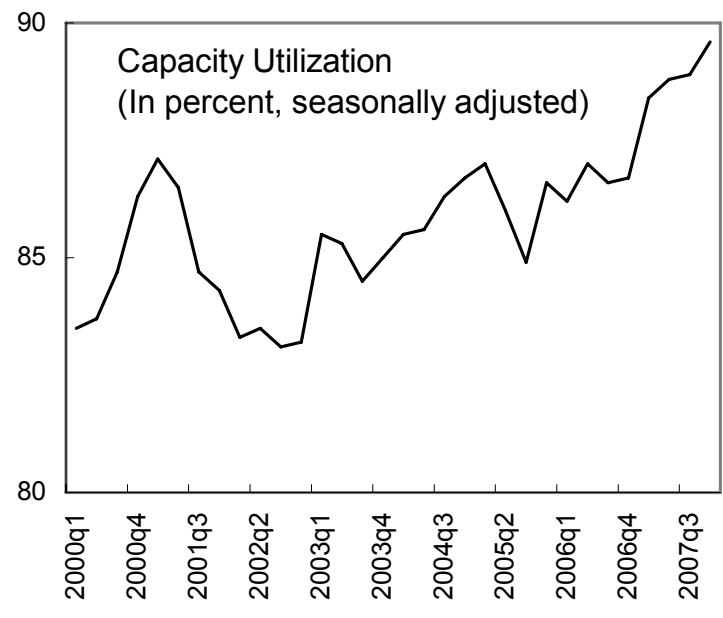

...wage pressures are on the rise.

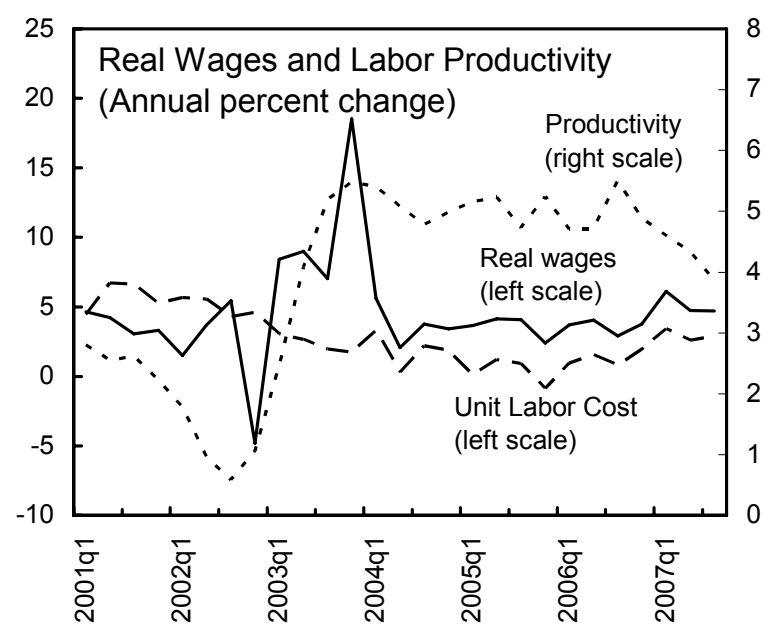

Source: Czech Statistical Office; European Commission; Eurostat; and IMF staff calculations. 
Figure 3. Czech Republic: External Sector Developments, 2001-07 (In percent of GDP, unless otherwise indicated)

Export growth remained strong leading to an increasing trade surplus.

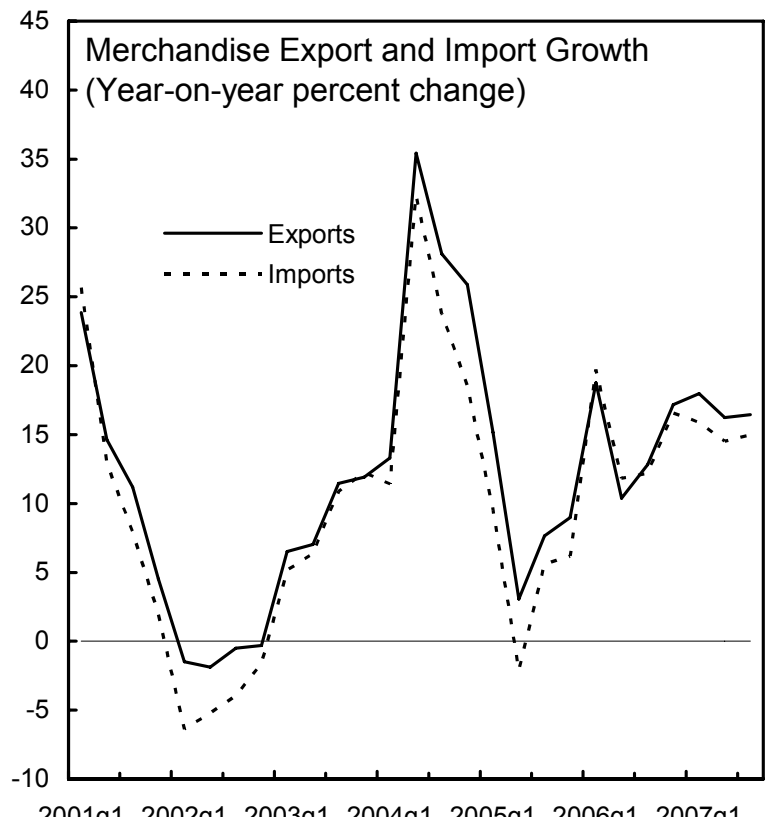

...but it continues to be comfortably financed by FDI inflows.

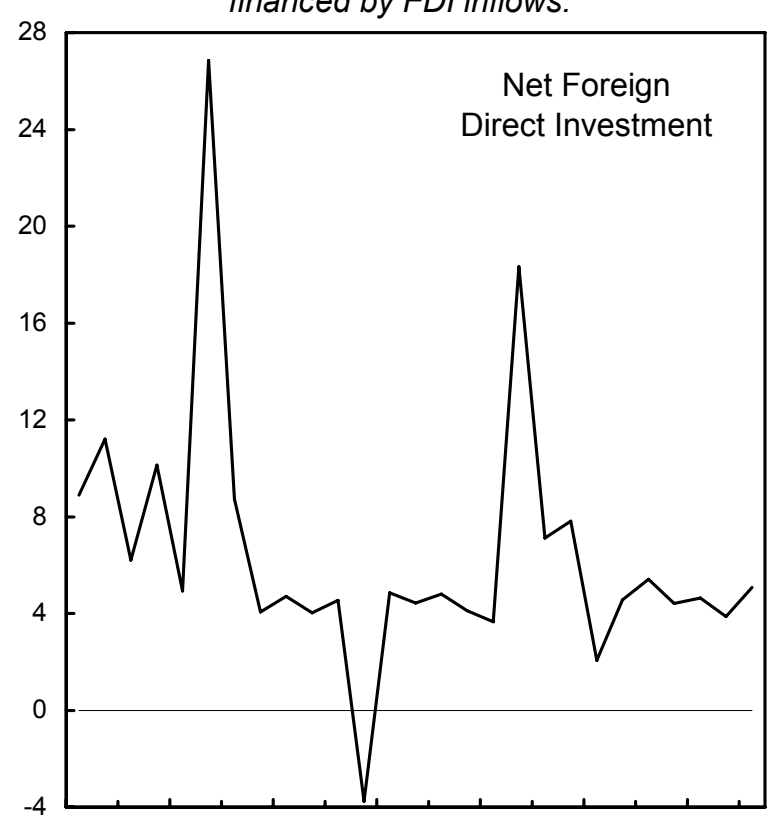

2001q1 2002q1 2003q1 2004q1 2005q1 2006q1 2007q1
Nevertheless, the current account deficit has widened owing to profit repratiations...

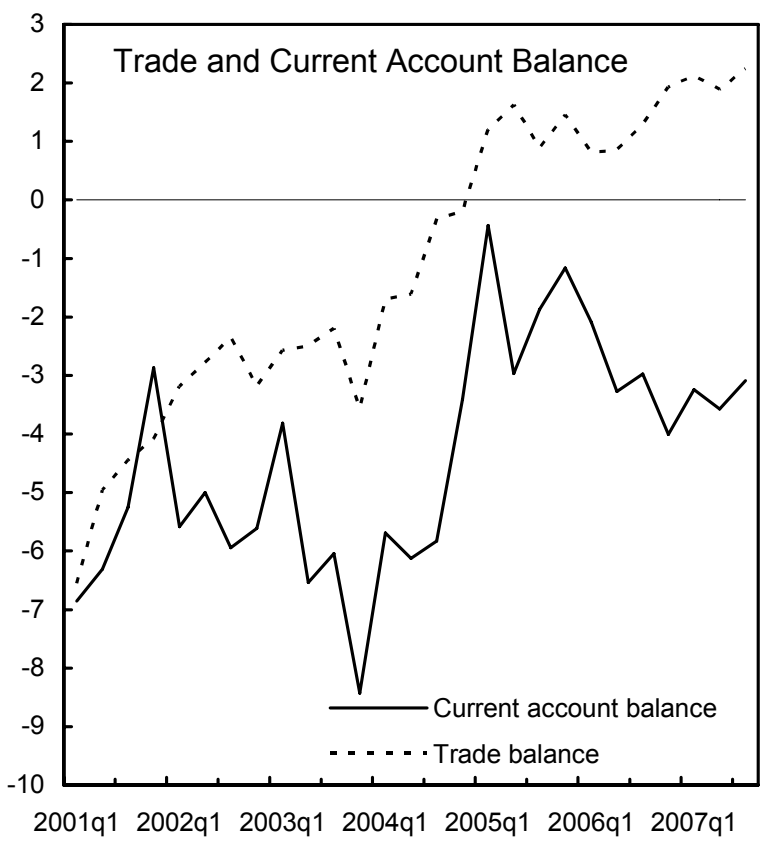

Portfolio outflows have been volatile.

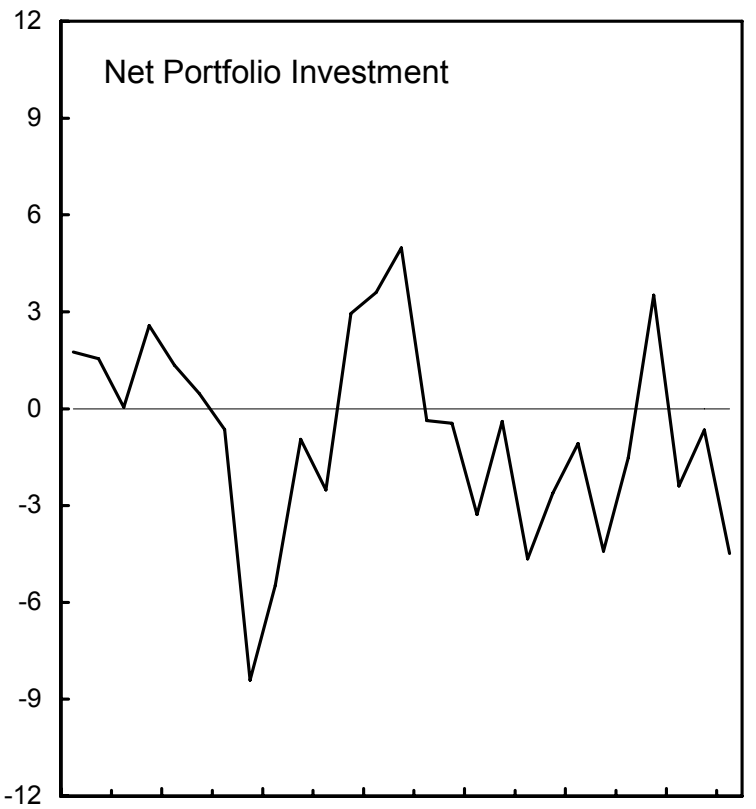

2001q1 2002q1 2003q1 2004q1 2005q1 2006q1 2007q1

Sources: Czech National Bank; Czech Statistical Office; and IMF staff estimates. 
Figure 4. Czech Republic: Monetary Policy Indicators, 2003-07

Policy rates have been

rising steadily since mid-2007...

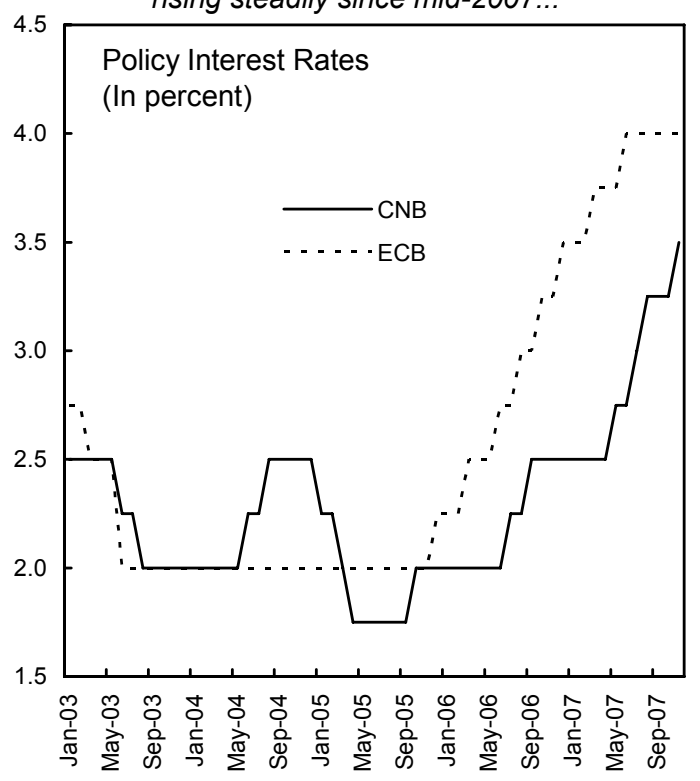

Recently, a pickup in inflation has led to

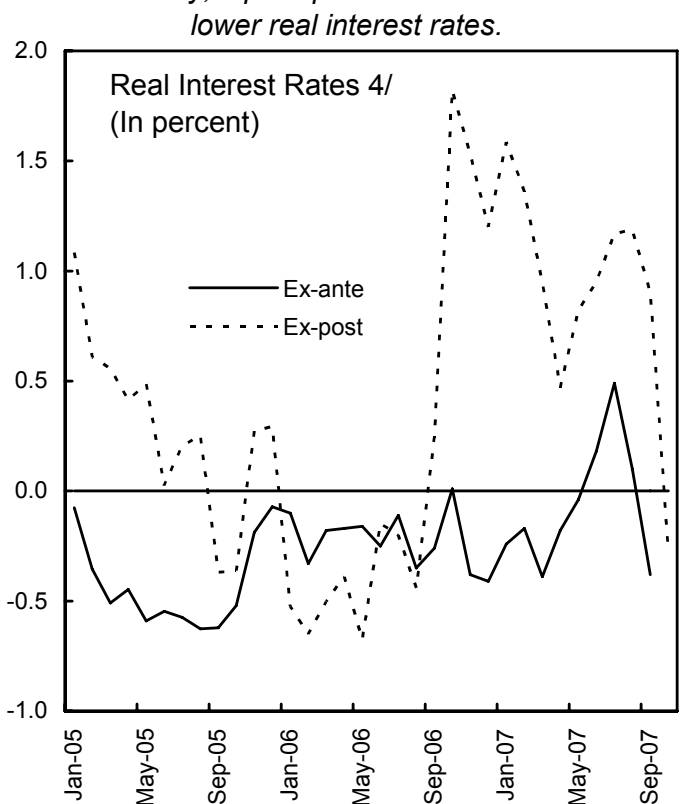

...as the monetary policy stance tightened.

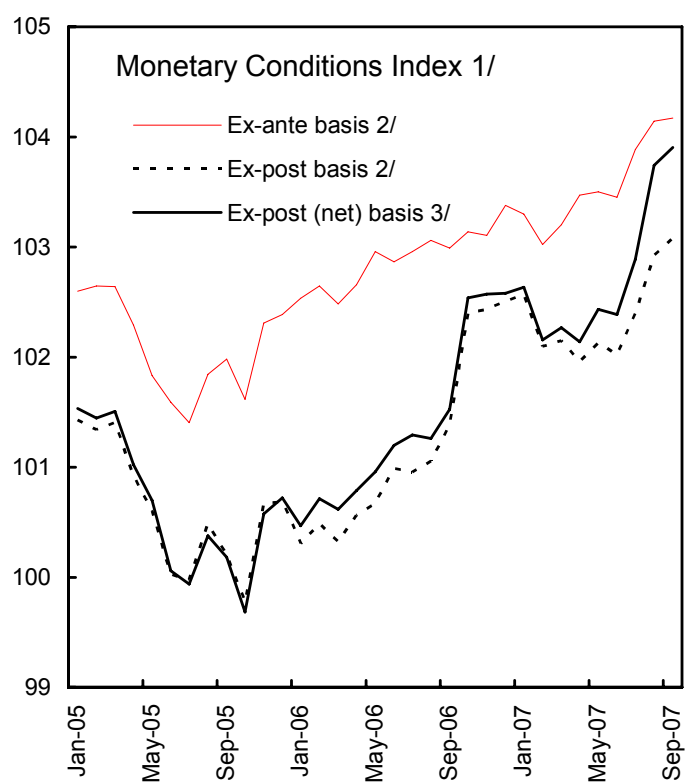

Credit to the private sector continues to grow rapidly.

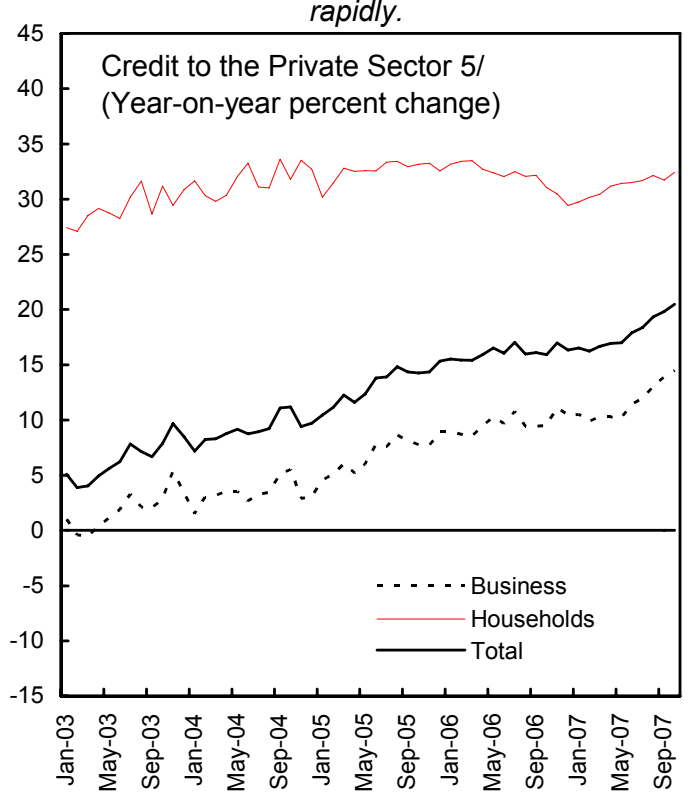

Sources: Czech National Bank; European Central Bank; and IMF staff estimates.

$1 /$ Weighted average of real short-term interest rate and real effective exchange rate (weights: $2 / 3$ and 1/3, respectively). January $2003=100$.

2/ Based on 1-year PRIBOR deflated by 12-month backward and forward-looking CPI inflation, respectively. 3 / Based on interest rate deflated by 12-month backward-looking inflation excluding first-round impacts of changes to indirect taxes.

4/ Ex post real interest rates are 1-year PRIBOR, deflated by 12-month CPI inflation; ex ante real interest rates are deflated by 12-month inflation expected in a survey conducted by the Czech National Bank Statistical Survey.

5/ Business and total adjusted for loan write-offs and changes in classification of financial institutions. 
Figure 5. Czech Republic: Financial Indicators, 2003-07

The depreciation of the koruna reversed after the recent financial turmoil...

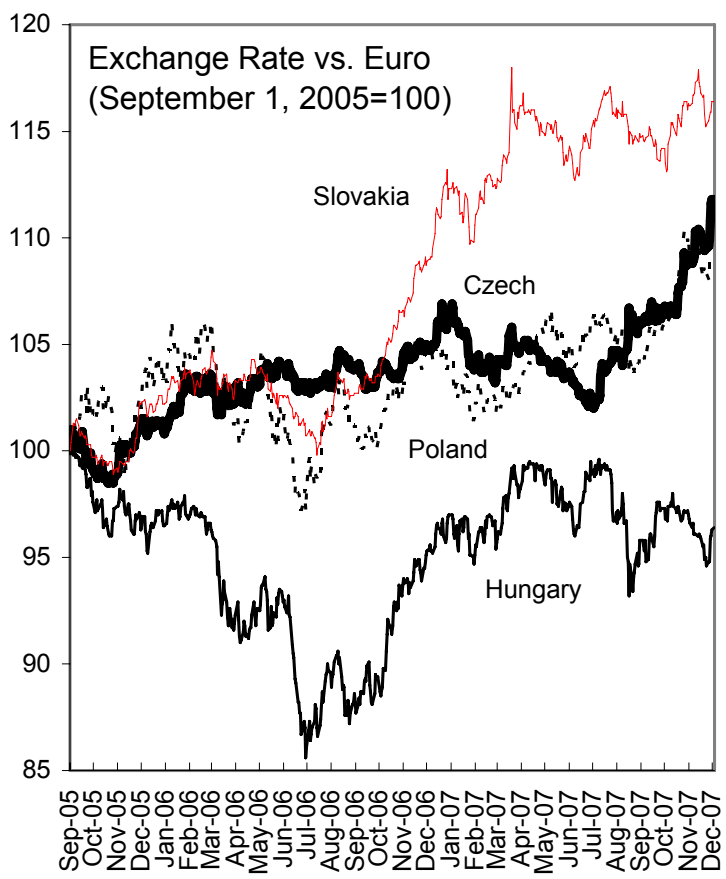

International bond spreads remained very small...

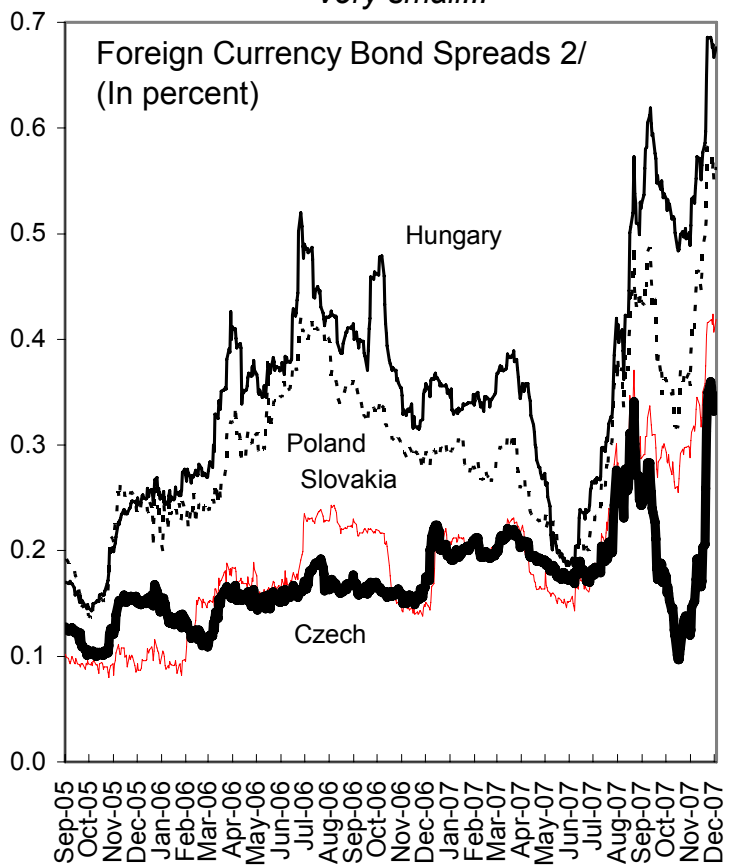

...but volatility remained low.

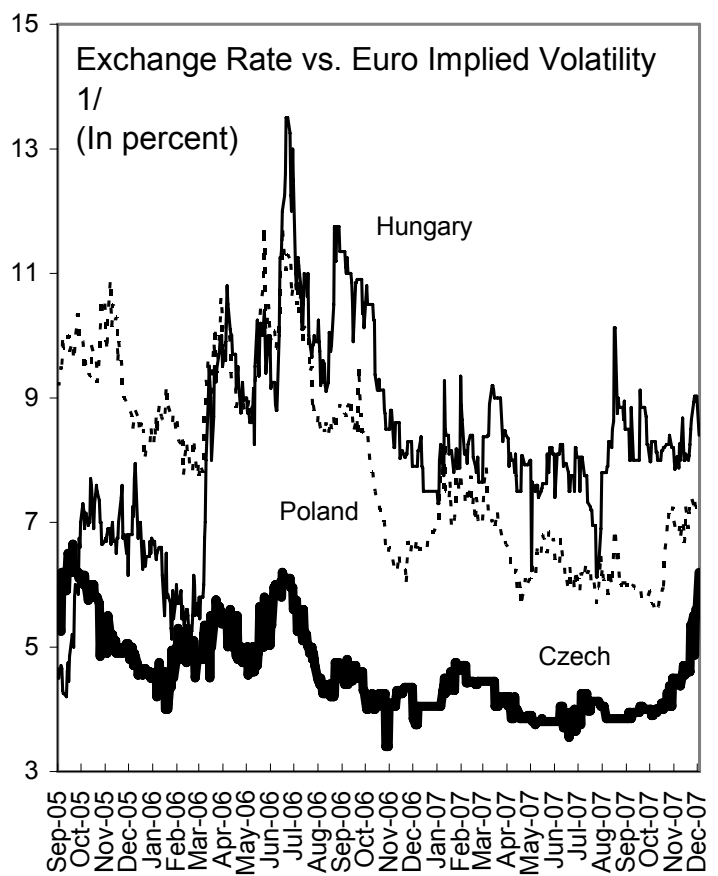

...while the effect on credit default swaps was limited.

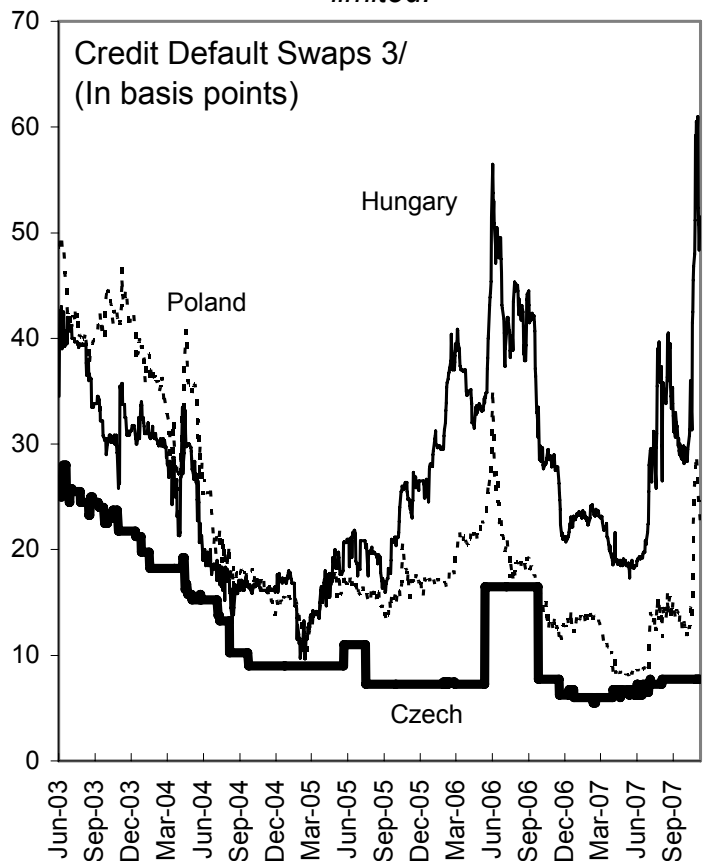

Source: Bloomberg.

1/ The volatility implied by the market price of a 1-month option contract based on a theoretical pricing model. Implied volatility includes future expectations of price movement, which are not reflected in historical volatility.

2/ Spread of 5-year euro denominated international government bond versus 5-year Bund.

3/ Five-year credit default swap spreads on sovereign debt. 
Figure 6. Czech Republic: Financial Indicators, 2005-07

The stock market fell sharply during the recent financial turmoil...

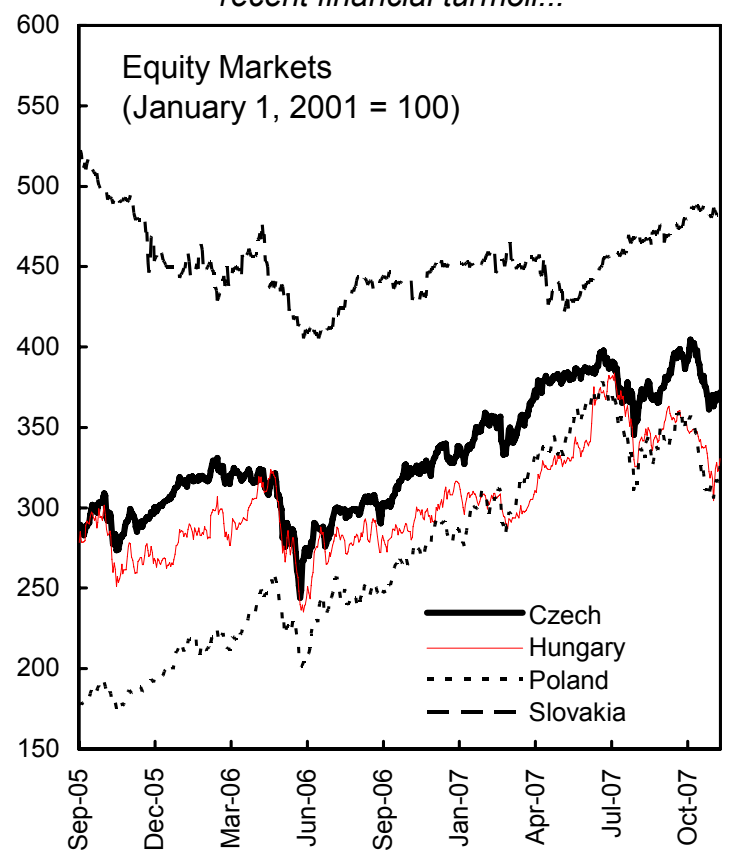

The interest rate has already converged with the Euro area rate...

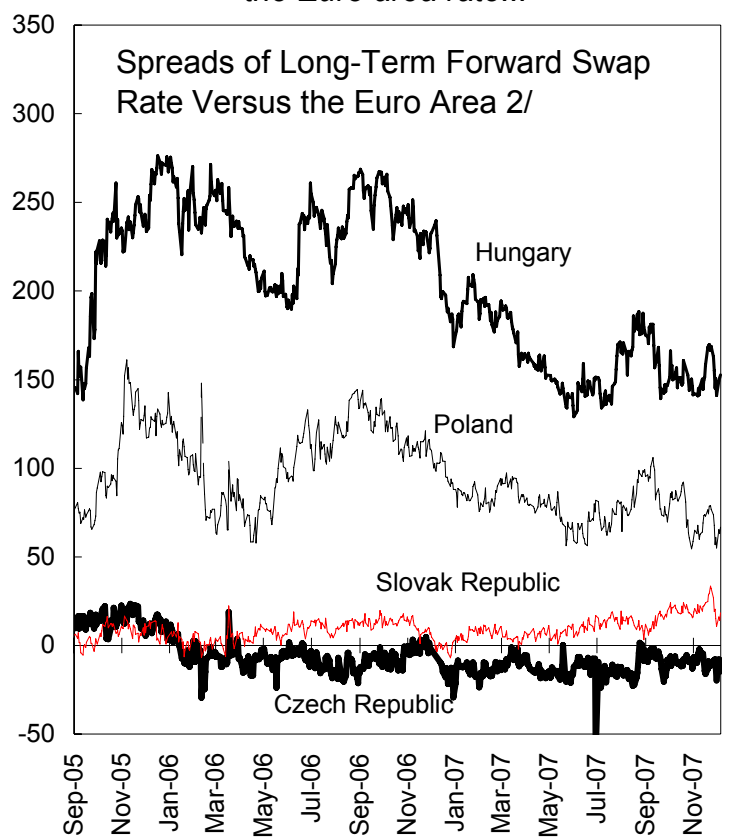

...while long-term interest rates reflected the recent tightening of monetary policy.

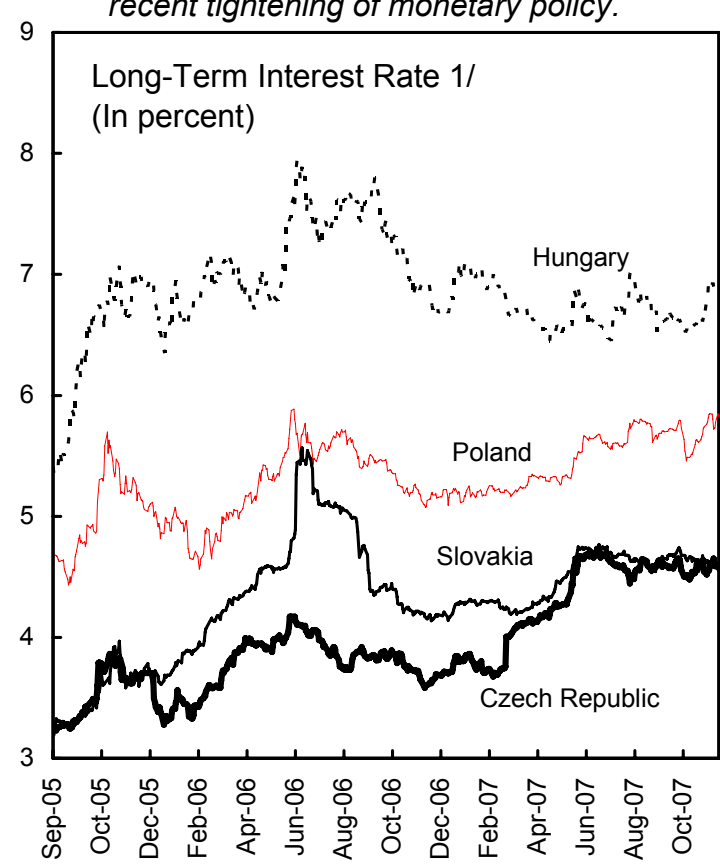

... with the policy rate the lowest in the region.

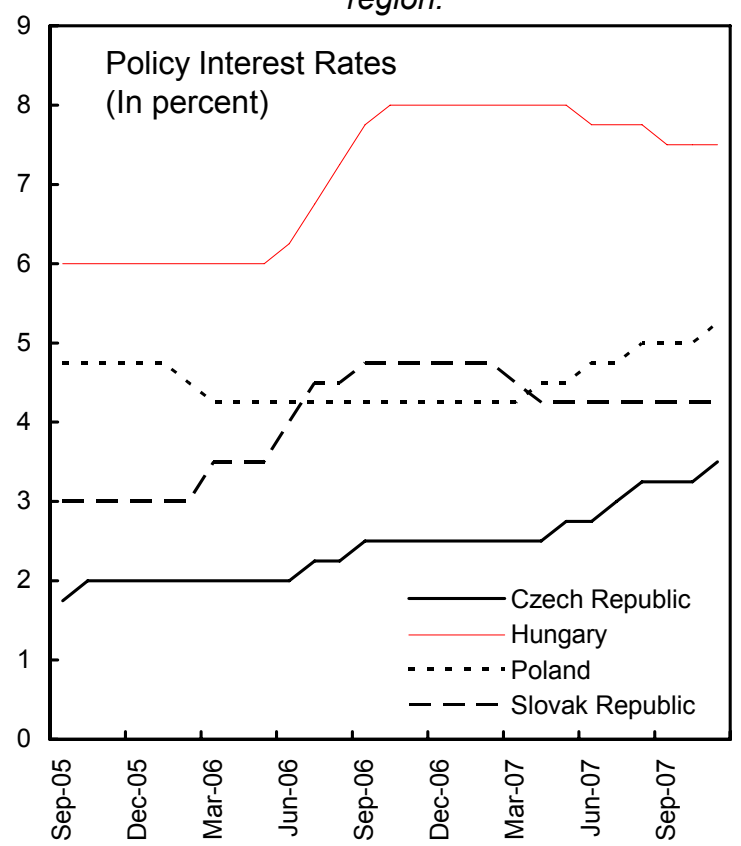

Sources: Bloomberg; Czech National Bank; and IMF staff estimates.

1/ 10-year government bond yield.

2/ Five-year interest rate, in five years time, in basis points. 
Figure 7. Country: External Debt Sustainability: Bound Tests 1/

(External debt in percent of GDP)
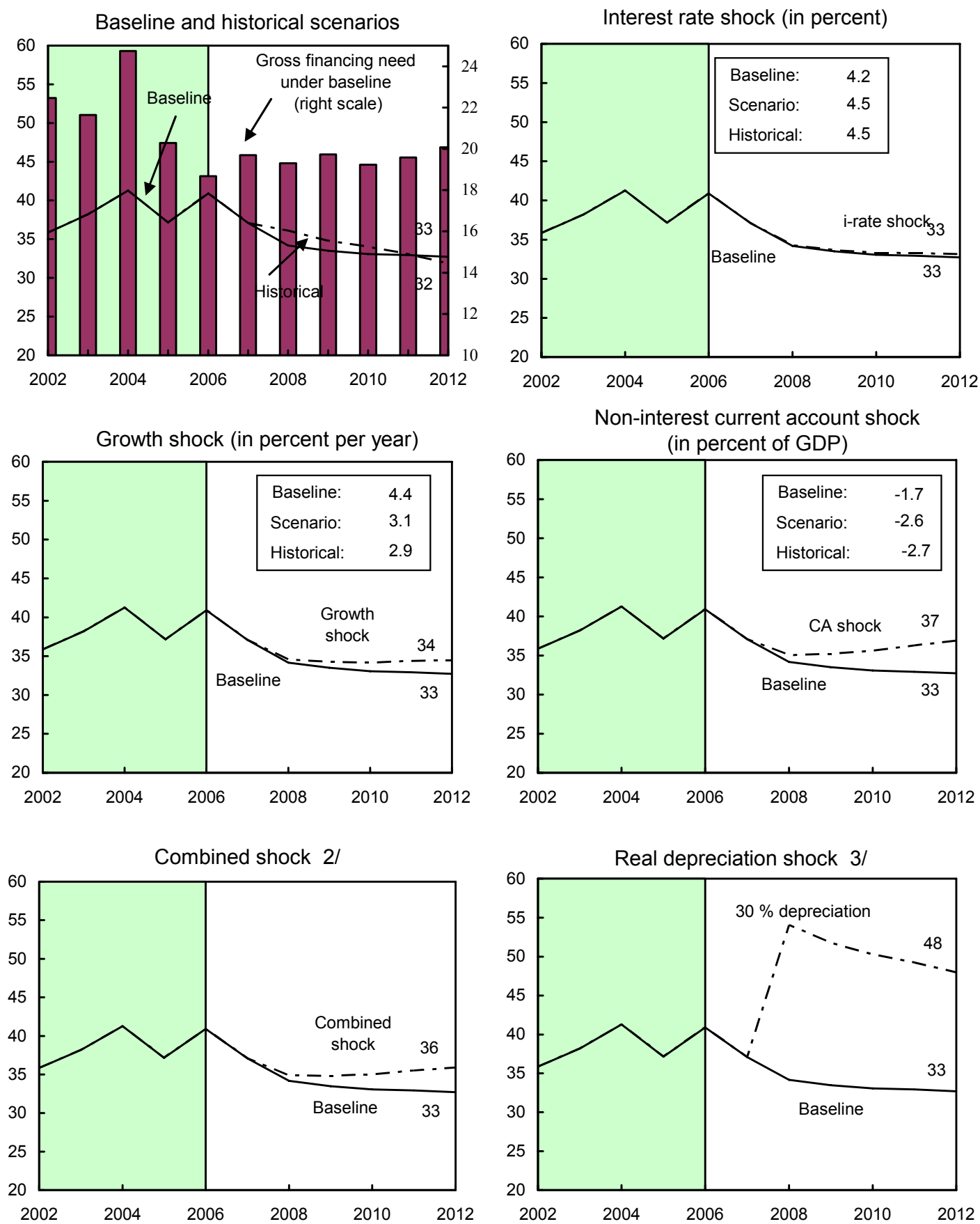

Sources: International Monetary Fund, Country desk data, and staff estimates.

$1 /$ Shaded areas represent actual data. Individual shocks are permanent one-half standard deviation shocks.

Figures in the boxes represent average projections for the respective variables in the baseline and scenario being presented. Ten-year historical average for the variable is also shown.

2/ Permanent 1/4 standard deviation shocks applied to real interest rate, growth rate, and current account balance.

3/ One-time real depreciation of 30 percent occurs in 2008. 
Figure 8. Czech Republic: Labor Market Indicators, 1999-2006

Labor participation among the young and less educated has been declining
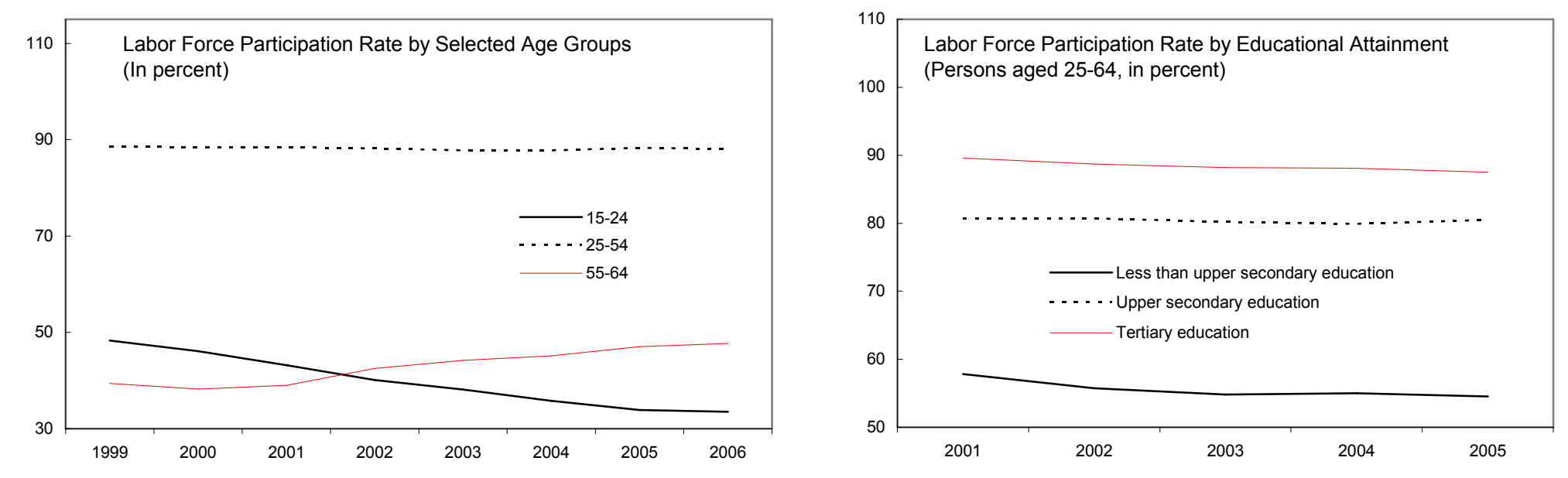

\begin{tabular}{|c|c|c|c|c|c|c|c|c|c|c|c|}
\hline & \multicolumn{3}{|c|}{ Tax-benefit wedge } & \multirow{2}{*}{$\begin{array}{c}\text { Regional } \\
\text { Mismatches } \\
\text { Gini Index of } \\
\text { Regional } \\
\text { Disparities in } \\
\text { Unemployment } \\
\text { rates }\end{array}$} & \multicolumn{3}{|c|}{$\begin{array}{c}\text { Labor Market Flexibility } \\
\text { Employment Protection Strictness } \\
\text { Index, } 2003 \\
\end{array}$} & \multicolumn{4}{|c|}{$\begin{array}{c}\text { Skills Mismatches } \\
\text { Unemployment Rates by } \\
\text { Educational Attainment } \\
\end{array}$} \\
\hline & $\begin{array}{l}\text { Out-of- } \\
\text { work } \\
\text { benefits, } \\
20041 /\end{array}$ & $\begin{array}{c}\text { Implicit } \\
\text { tax rate } \\
\text { on labor, } \\
2005\end{array}$ & $\begin{array}{l}\text { Unemployment } \\
\text { Trap, } 20052 /\end{array}$ & & $\begin{array}{c}\text { Regular } \\
\text { Employment }\end{array}$ & $\begin{array}{l}\text { Temporary } \\
\text { Employment }\end{array}$ & $\begin{array}{l}\text { Collective } \\
\text { Dismissals }\end{array}$ & Primary & Secondary & Tertiary & Overall \\
\hline Czech Rep. & 60 & 41.3 & 66 & 0.22 & 3.3 & 0.5 & 2.1 & 27 & 7 & 2 & 8 \\
\hline Hungary & 31 & 40.5 & 55 & 0.18 & 1.9 & 1.1 & 2.9 & 14 & 7 & 3 & 7 \\
\hline Poland & 59 & 35.5 & 81 & 0.15 & 2.2 & 1.3 & 4.1 & 30 & 19 & 7 & 18 \\
\hline Slovakia & 40 & 33.7 & 43 & 0.23 & 3.5 & 0.4 & 2.5 & 53 & 14 & 5 & 16 \\
\hline OECD & 57 & $\ldots$ & $\ldots$ & 0.19 & $\ldots$ & $\ldots$ & $\ldots$ & $\ldots$ & $\ldots$ & $\ldots$ & $\ldots$ \\
\hline Euro Area & $\ldots$ & 36.8 & 77 & $\ldots$ & 2.5 & 2.3 & 3.3 & 12 & 9 & 6 & 9 \\
\hline EU8 & & 35.6 & $\ldots$ & n.a. & 2.7 & 1.3 & 3.2 & 23 & 10 & 4 & 10 \\
\hline
\end{tabular}

Source: OECD Society at a Glance (2007), Regions at a Glance (2007), Eurostat, Arratibel, et. al. (2007).

1/ Average of Net Replacement Rates over 60 months of unemployment. Unemployment benefits plus additional social assistance, in percent.

2/ Percentage of gross earnings which is "taxed away" through higher tax and social security contributions and the withdrawal of unemployment and other benefits when an unemployed person returns to employment. This structural indicator covers single persons without children earning, when in work, $67 \%$ of the average earnings. 
Figure 9. Country: Public Debt Sustainability: Bound Tests 1/

(Public debt in percent of GDP)
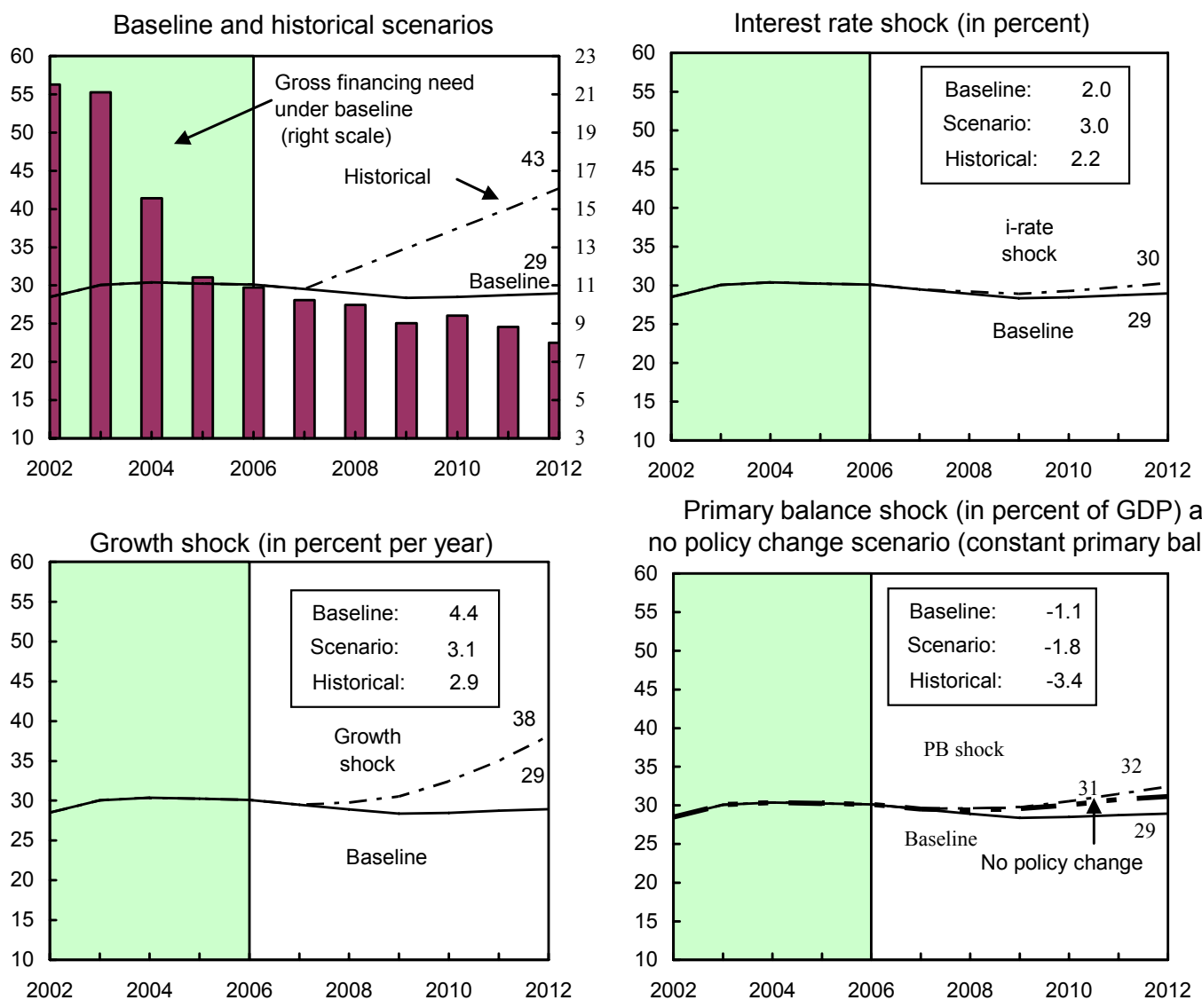

Primary balance shock (in percent of GDP) and no policy change scenario (constant primary balance)

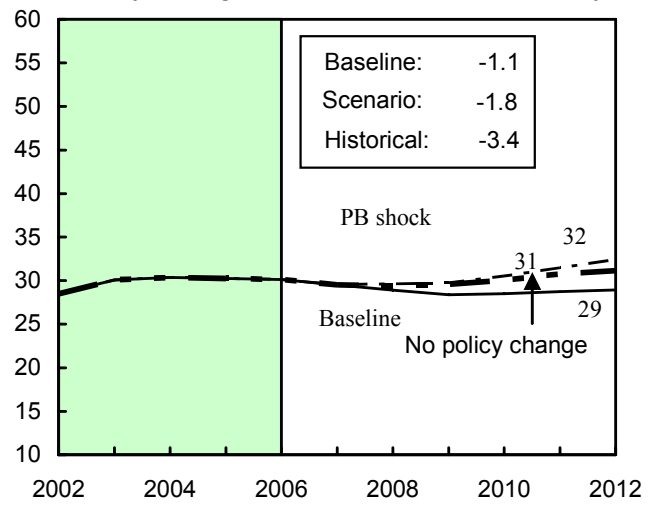

Combined shock 2/

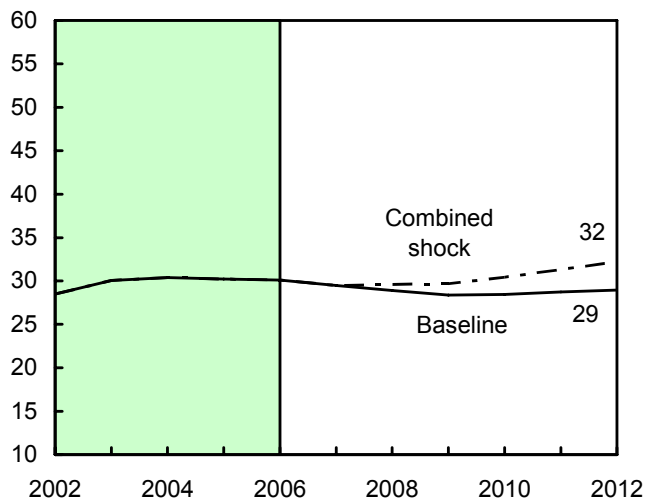

Real depreciation and contingent liabilities shocks $3 /$

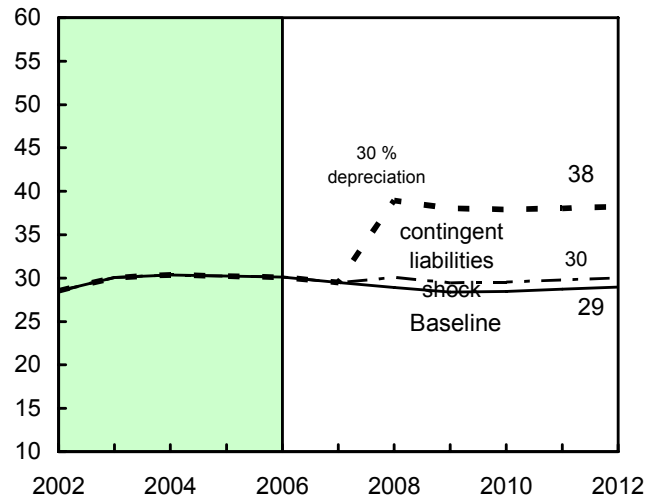

Sources: International Monetary Fund, country desk data, and staff estimates.

$1 /$ Shaded areas represent actual data. Individual shocks are permanent one-half standard deviation shocks. Figures in the boxes represent average projections for the respective variables in the baseline and scenario being presented. Ten-year historical average for the variable is also shown.

2/ Permanent $1 / 4$ standard deviation shocks applied to real interest rate, growth rate, and primary balance.

3 / One-time real depreciation of 30 percent and 10 percent of GDP shock to contingent liabilities occur in 2008, with real depreciation defined as nominal depreciation (measured by percentage fall in dollar value of local currency) minus domestic inflation (based on GDP deflator). 
Figure 10. Czech Republic: Exchange Rate Indicators, 2000-2007 $(2000 q 1=100) 1 /$
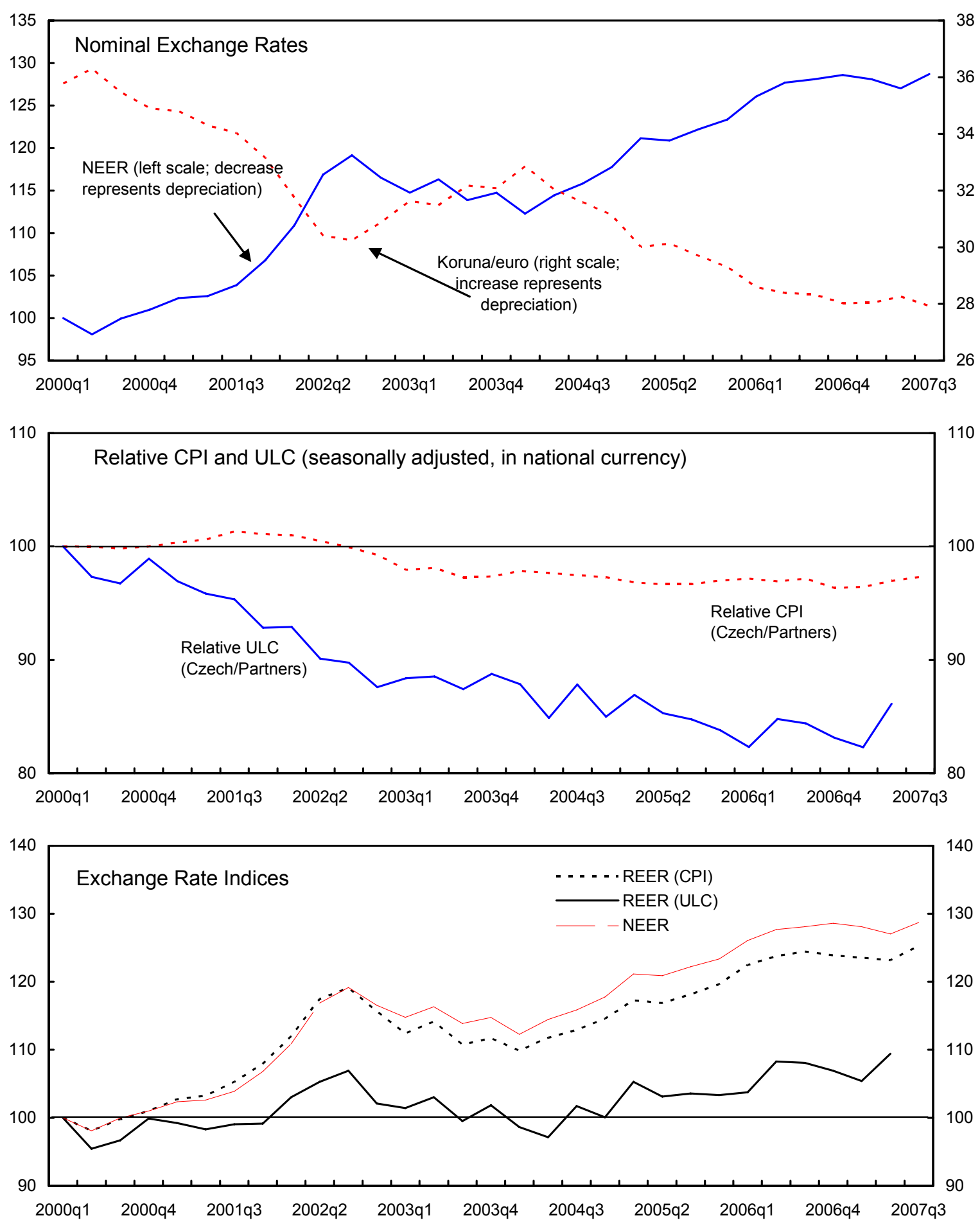

Sources: CNB; Eurostat; IFS; and IMF staff calculations.

1/ Trade weights based on 2000-2003 data for exports of goods. Partner countries comprise:

Austria, Belgium, France, Germany, Hungary, Italy, Netherlands, Poland, Russia, Slovak Republic, United Kingdom, and United States. 
Figure 11. Czech Republic: Wages and Productivity in Manufacturing, 2000-2007 $(1998 q 1=100) 1 /$
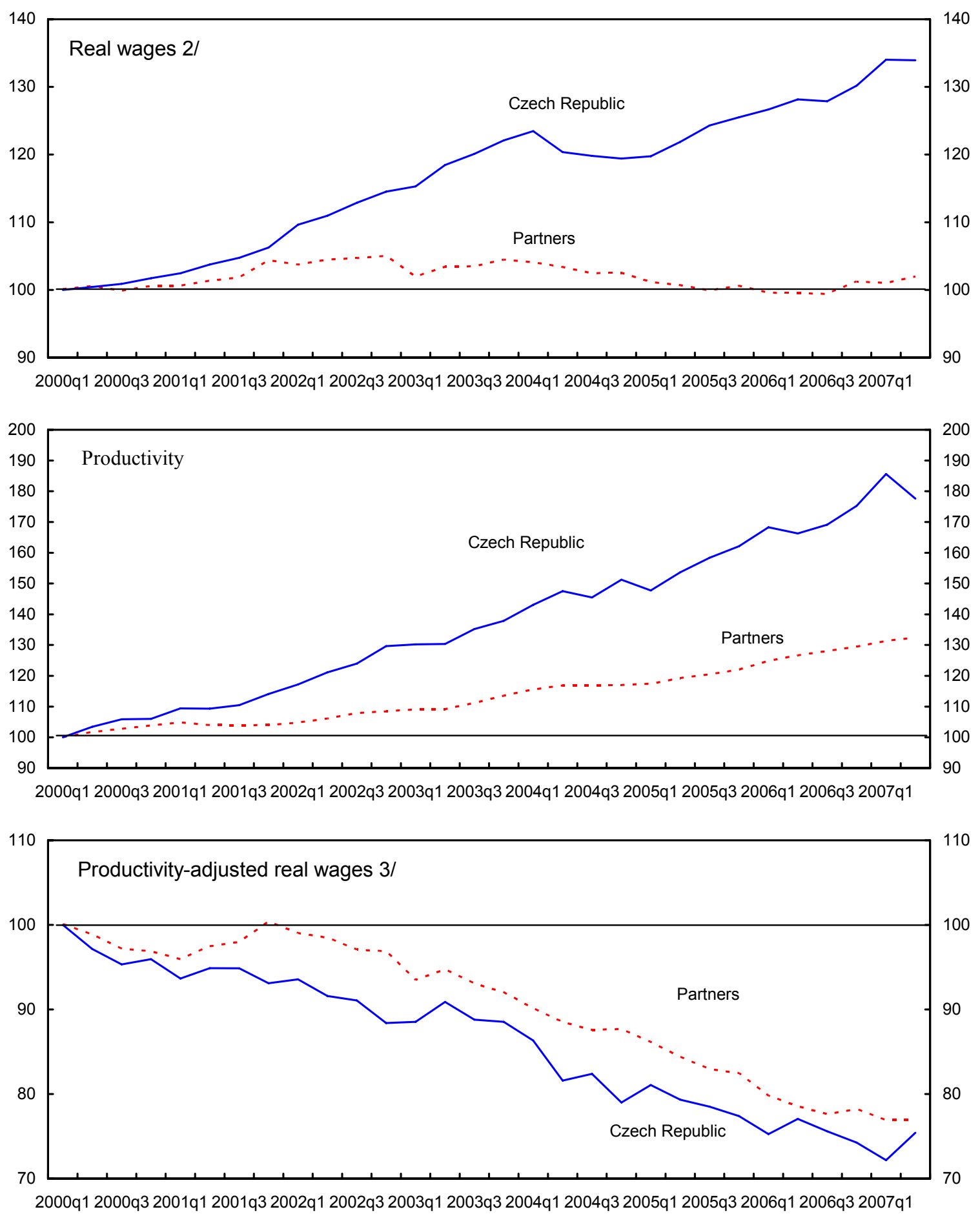

Sources: Statistical Office of the Czech Republic; and IMF staff calculations.

1/ Partner countries comprise: Austria, Belgium, France, Germany, Hungary, Italy, Netherlands,

Poland, Russia, Slovak Republic, United Kingdom, and United States.

2/ Defined as the ratio of nominal wages to producer price index.

$3 /$ Defined as the ratio of real wages to productivity.

\section{CInternational Monetary Fund. Not for Redistribution}


Table 1. Czech Republic: Selected Economic Indicators, 2002-08

\begin{tabular}{|c|c|c|c|c|c|c|c|}
\hline & 2002 & 2003 & 2004 & 2005 & 2006 & 2007 & 2008 \\
\hline & & & & & & \multicolumn{2}{|c|}{ Staff Proj. } \\
\hline \multicolumn{8}{|l|}{ Real economy (change in percent) } \\
\hline Real GDP & 1.9 & 3.6 & 4.5 & 6.4 & 6.4 & 5.9 & 4.6 \\
\hline Domestic demand & 4.0 & 4.1 & 3.2 & 1.2 & 5.7 & 6.6 & 4.9 \\
\hline CPI (year average) & 1.8 & 0.1 & 2.8 & 1.8 & 2.5 & 3.0 & 5.4 \\
\hline PPI (year average) & -0.5 & -0.3 & 5.7 & 3.0 & 1.6 & n.a. & n.a. \\
\hline \multicolumn{8}{|l|}{ Unemployment rate (in percent) } \\
\hline Survey-based $1 /$ & 7.3 & 7.8 & 8.3 & 7.9 & 7.1 & 5.5 & 4.9 \\
\hline Registered $1 /$ & 9.2 & 9.9 & 9.8 & 8.9 & 8.1 & 6.4 & 5.8 \\
\hline Gross national savings (percent of GDP) & 23.2 & 21.1 & 22.4 & 24.2 & 23.8 & 23.5 & 23.3 \\
\hline Gross domestic investments (percent of GDP) & 28.7 & 27.4 & 27.6 & 25.8 & 26.9 & 26.9 & 26.8 \\
\hline \multicolumn{8}{|l|}{ Public finance (percent of GDP) 2/ } \\
\hline General government revenue & 39.5 & 40.7 & 42.2 & 41.2 & 40.8 & 40.4 & 40.1 \\
\hline General government expenditure & 46.3 & 47.3 & 45.1 & 44.8 & 43.8 & 43.2 & 42.3 \\
\hline Net lending & -6.8 & -6.6 & -2.9 & -3.5 & -2.9 & -2.8 & -2.2 \\
\hline General government debt & 28.5 & 30.1 & 30.4 & 30.2 & 30.2 & 29.5 & 28.9 \\
\hline \multicolumn{8}{|l|}{ Money and credit (end of year, percent change) } \\
\hline Broad money $3 /$ & 3.5 & 6.9 & 4.4 & 8.0 & 9.9 & 10.6 & n.a. \\
\hline Private sector credit (percent change, eop) $3 /$ & 4.5 & 11.8 & 15.3 & 20.8 & 21.6 & 25.9 & n.a. \\
\hline \multicolumn{8}{|l|}{ Interest rates (in percent, year average) } \\
\hline Three-month interbank rate $3 /$ & 2.6 & 2.1 & 2.6 & 2.2 & 2.6 & 3.6 & n.a. \\
\hline Ten-year government bond 4/ & 4.2 & 4.8 & 4.0 & 3.6 & 3.7 & 4.5 & n.a. \\
\hline \multicolumn{8}{|l|}{ Balance of payments (percent of GDP) } \\
\hline Trade balance & -2.9 & -2.7 & -0.5 & 2.0 & 2.1 & 2.4 & 2.8 \\
\hline Current account & -5.5 & -6.2 & -5.2 & -1.6 & -3.1 & -3.4 & -3.5 \\
\hline Gross international reserves (US\$ billion) & 23.7 & 27.0 & 28.4 & 29.6 & 31.5 & 34.0 & 37.0 \\
\hline Reserve cover (in months of imports of goods and services) & 6.1 & 5.5 & 4.5 & 4.1 & 3.6 & 2.9 & 2.6 \\
\hline \multicolumn{8}{|l|}{ Exchange rate } \\
\hline Nominal effective exchange rate, pa $(2000=100) 5 /$ & 116.5 & 116.8 & 118.0 & 125.3 & 131.7 & 136.5 & n.a. \\
\hline Real effective exchange rate, pa $(C P I-b a s e d ; 2000=100) 5 /$ & 118.7 & 116.8 & 118.3 & 125.3 & 132.3 & 138.0 & n.a. \\
\hline
\end{tabular}

Sources: Czech Statistical Office; Czech National Bank; Ministry of Finance; and Fund staff estimates and projections.

$1 /$ In percent of total labor force.

2/ On ESA-95 basis.

3/ For 2007, data refer to October.

4/ For 2007, data refer to November.

5/ For 2007, data refer to September. 
Table 2. Czech Republic: Balance of Payments, 2002-08

(In millions of US Dollars)

\begin{tabular}{|c|c|c|c|c|c|c|c|}
\hline & 2002 & 2003 & 2004 & 2005 & 2006 & $\begin{array}{r}2007 \\
\text { Est. }\end{array}$ & $\begin{array}{l}2008 \\
\text { Proj. }\end{array}$ \\
\hline Current account balance & -4264 & -5785 & -5738 & -2024 & -4440 & -6002 & -7189 \\
\hline Trade balance & -2239 & -2519 & -530 & 2522 & 2979 & 4251 & 5741 \\
\hline Exports & 38469 & 48701 & 67239 & 77973 & 95115 & 128128 & 157672 \\
\hline Imports & 40709 & 51221 & 67768 & 75451 & 92136 & 123878 & 151930 \\
\hline Nonfactor services & 643 & 470 & 636 & 1532 & 1531 & 1117 & 806 \\
\hline Receipts & 7081 & 7789 & 9646 & 11752 & 13331 & 16219 & 18446 \\
\hline Payments & 6438 & 7319 & 9010 & 10220 & 11801 & 15101 & 17640 \\
\hline Factor income (net) & -3579 & -4285 & -6095 & -6499 & -8118 & -10171 & -10777 \\
\hline Transfers & 912 & 548 & 236 & 492 & -891 & -1199 & -2960 \\
\hline Capital account & -4 & -3 & -603 & 196 & 380 & 649 & 1342 \\
\hline Financial account balance & 10617 & 5620 & 7041 & 5622 & 3352 & 6002 & 7189 \\
\hline Direct investment, net & 8282 & 1814 & 3941 & 11630 & 4667 & 7154 & 8143 \\
\hline Portfolio investment, net & -1558 & -1181 & 1988 & -3390 & -1132 & -1132 & -626 \\
\hline Financial derivatives, net & -130 & 143 & -146 & -112 & -286 & 541 & 0 \\
\hline Other investment, net & 4023 & 4844 & 1259 & -2618 & -183 & -20 & -328 \\
\hline Errors and omissions, net & 262 & 609 & -440 & 86 & 800 & 0 & 0 \\
\hline Change in reserves $2 /$ & -6612 & -441 & -261 & -3879 & -92 & -649 & -1342 \\
\hline \multicolumn{8}{|l|}{ Memorandum items: } \\
\hline Current account (in percent of GDP) & -5.5 & -6.2 & -5.2 & -1.6 & -3.1 & -3.4 & -3.5 \\
\hline Trade balance (in percent of GDP) & -3.0 & -2.8 & -0.5 & 2.0 & 2.1 & 2.4 & 2.8 \\
\hline Net foreign direct investment (in percent of GDP) & 11.0 & 2.0 & 3.6 & 9.3 & 3.3 & 4.1 & 4.0 \\
\hline \multicolumn{8}{|l|}{$\begin{array}{l}\text { Gross official reserves } \\
\text { (in months of the following year's imports of goods }\end{array}$} \\
\hline and non-factor services) & 5.7 & 4.6 & 4.3 & 3.6 & 3.1 & 2.6 & 2.3 \\
\hline (as a ratio to the short-term debt by remaining maturity) & 1.8 & 1.5 & 1.2 & 1.3 & 1.2 & 1.1 & 1.0 \\
\hline Terms of trade $3 /$ & 3.1 & 0.4 & 1.2 & -1.8 & -1.1 & 0.1 & 0.3 \\
\hline
\end{tabular}

Sources: Czech National Bank; and IMF staff projections.

1/ IMF staff estimates or projections.

2/ Changes in reserves reflect off-market conversion of large privatization receipts, EU transfers, and sales of accumulated interest.

$3 /$ Goods and services. 
Table 3. Czech Republic: Consolidated General Government Budget, 2002-08 1/ (on ESA-95 basis)

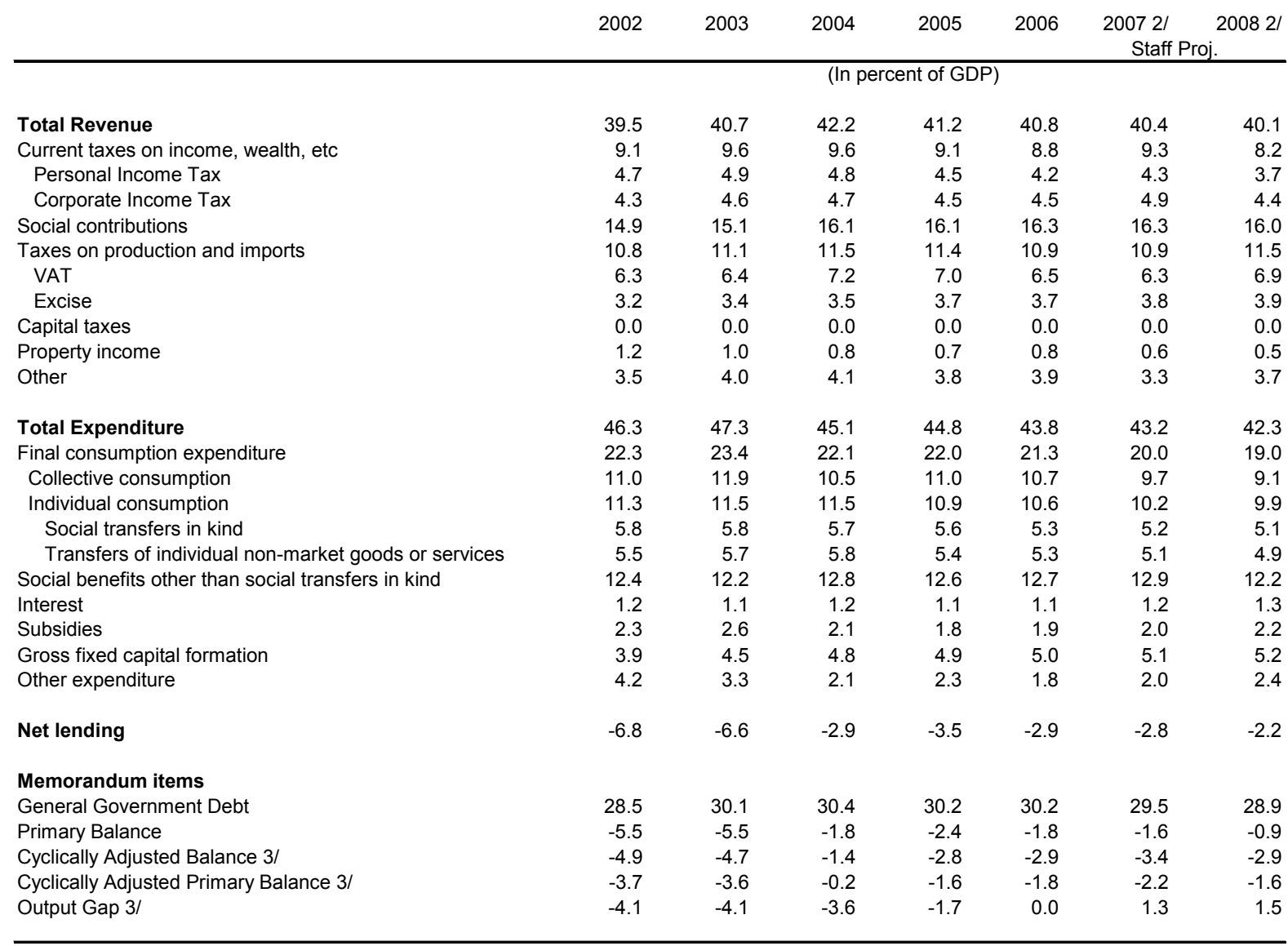

Sources: Ministry of Finance and Fund staff estimates.

$1 /$ On accrual basis. Includes financial transations and broader coverage of institutions (such as the Czech Consolidation Agency and the Railways) that is excluded from the GFS-86 fiscal accounts.

2/ Staff projections.

3/ Staff estimates of output gap. 
Table 4. Czech Republic: Selected Vulnerability Indicators

\begin{tabular}{|c|c|c|c|c|c|c|c|c|c|}
\hline & 2000 & 2001 & 2002 & 2003 & 2004 & 2005 & 2006 & $20071 /$ & $\begin{array}{r}\text { Latest } \\
\text { observation }\end{array}$ \\
\hline \multicolumn{10}{|l|}{ Key Economic and Market Indicators } \\
\hline Real GDP growth (in percent) & 3.6 & 2.5 & 1.9 & 3.6 & 4.5 & 6.4 & 6.4 & 5.9 & Proj \\
\hline CPI inflation (period average, in percent) & 3.8 & 4.7 & 1.8 & 0.1 & 2.8 & 1.8 & 2.5 & 3.0 & Proj \\
\hline Short-term (ST) interest rate (in percent) $2 /$ & 5.4 & 4.7 & 2.6 & 2.1 & 2.6 & 2.2 & 2.6 & 3.6 & Oct-07 \\
\hline EMBI secondary market spread (bps, end of period) $3 /$ & $\ldots$ & $\ldots$ & $\ldots$ & $\ldots$ & 14.7 & 14.2 & 19.8 & 33.2 & Nov- 07 \\
\hline Exchange rate NC/US\$ (end of period) & 37.8 & 36.3 & 30.1 & 25.7 & 22.4 & 24.6 & 20.9 & 18.7 & Oct-07 \\
\hline \multicolumn{10}{|l|}{ External Sector } \\
\hline Exchange rate regime & \multicolumn{7}{|c|}{ Managed floating } & & \\
\hline Current account balance (percent of GDP) & -4.8 & -5.3 & -5.5 & -6.2 & -5.2 & -1.6 & -3.1 & -3.4 & Proj \\
\hline Net FDI inflows (percent of GDP) & 8.7 & 8.9 & 11.0 & 2.0 & 3.6 & 9.3 & 3.3 & 4.1 & Proj \\
\hline Exports (percentage change of US\$ value, GNFS) & 7.7 & 13.0 & 12.5 & 24.0 & 35.7 & 17.1 & 20.5 & 33.4 & Proj \\
\hline Real effective exchange rate $(2000=100)$ & 100.0 & 106.4 & 118.7 & 116.8 & 118.3 & 125.3 & 132.3 & 138.0 & Sep-07 \\
\hline Gross international reserves (GIR) in US $\$$ billion & 13.1 & 14.5 & 23.7 & 27.0 & 28.4 & 29.6 & 31.5 & 34.0 & Proj \\
\hline GIR in percent of ST debt at remaining maturity (RM) & 103.9 & 112.4 & 114.4 & 169.5 & 126.1 & 122.0 & 133.2 & 109.8 & Proj \\
\hline Total gross external debt (ED) in percent of GDP & 38.1 & 36.2 & 35.8 & 38.2 & 41.3 & 37.2 & 40.8 & 37.4 & Proj \\
\hline o/w ST external debt (original maturity, in percent of total ED) & 42.1 & 42.6 & 38.7 & 40.1 & 34.0 & 31.4 & 30.6 & 31.5 & Proj \\
\hline ED of domestic private sector (in percent of total ED) & 96.0 & 96.1 & 94.0 & 92.2 & 85.0 & 80.0 & 79.6 & 77.3 & Proj \\
\hline ED to foreign official sector (in percent of total ED) & 8.8 & 9.0 & 8.8 & 9.6 & 8.6 & 9.4 & 9.2 & 9.1 & Proj \\
\hline Total gross external debt in percent of exports of GNFS & 60.3 & 55.3 & 59.2 & 61.8 & 59.0 & 51.7 & 53.9 & 45.8 & Proj \\
\hline Gross external financing requirement (in US $\$$ billion) $4 /$ & 15.0 & 15.0 & 16.9 & 19.8 & 27.1 & 25.3 & 26.6 & 34.6 & Proj \\
\hline \multicolumn{10}{|l|}{ Public Sector (PS) 5/ } \\
\hline Overall balance (percent of GDP) & -3.7 & -5.7 & -6.8 & -6.6 & -2.9 & -3.5 & -2.9 & -2.8 & Proj \\
\hline Primary balance (percent of GDP) & -2.9 & -4.7 & -5.5 & -5.5 & -1.8 & -2.4 & -1.8 & -1.6 & Proj \\
\hline Debt-stabilizing primary balance (percent of GDP) 6/ & $\ldots$ & $\ldots$ & $\ldots$ & $\ldots$ & $\ldots$ & $\ldots$ & -1.1 & -1.5 & Proj \\
\hline Gross PS financing requirement (in percent of GDP) 7/ & $\ldots$ & $\ldots$ & 16.7 & 15.5 & 13.3 & 9.8 & 11.5 & 9.3 & Proj \\
\hline Public sector gross debt (PSGD, in percent of GDP) & 18.5 & 25.1 & 28.5 & 30.1 & 30.4 & 30.2 & 30.1 & 29.5 & Proj \\
\hline \multicolumn{10}{|l|}{ Financial Sector (FS) 8/ } \\
\hline Capital adequacy ratio (in percent) & 17.4 & 15.0 & 14.2 & 14.5 & 12.6 & 11.9 & 11.4 & 11.9 & Sep-07 \\
\hline NPLs in percent of total loans & 29.3 & 13.7 & 10.6 & 4.9 & 4.1 & 4.3 & 3.6 & 3.0 & Sep-07 \\
\hline Return on average assets (in percent) $9 /$ & 0.7 & 0.7 & 1.1 & 1.2 & 1.3 & 1.4 & 1.2 & 1.3 & Sep-07 \\
\hline Return on equity (in percent) $10 /$ & $\ldots$ & 16.6 & 27.4 & 23.8 & 23.3 & 25.2 & 22.5 & 23.1 & Sep-07 \\
\hline FX deposits held by residents (in percent of total deposits) & 15.3 & 14.0 & 11.1 & 10.5 & 10.2 & 10.6 & 10.8 & 10.2 & Oct-07 \\
\hline FX loans to residents (in percent of total loans) & 21.6 & 18.1 & 15.8 & 14.1 & 13.4 & 13.0 & 13.6 & 13.7 & Sep-07 \\
\hline Credit to private sector (percent change) & -4.3 & 2.1 & 4.5 & 11.8 & 15.3 & 20.8 & 21.6 & 25.9 & Oct-07 \\
\hline \multicolumn{10}{|l|}{ Memo item: } \\
\hline Nominal GDP in billions of U.S. dollars & 56.7 & 61.8 & 75.3 & 91.4 & 109.5 & 124.7 & 143.0 & 176.5 & Proj \\
\hline
\end{tabular}

$1 /$ Staff estimates, projections, or latest available observations as indicated in the last column.

2/ Three-month interbank offer rate (PRIBOR), average.

3/ The Czech Republic is not included in the EMBI index. The column reports the spread between the domestic benchmark bond and a German bond of the same maturity.

4/ Current account deficit, amortization of medium and long term debt, plus short-term debt by remaining maturity.

5/ On ESA-95 basis. Public sector covers: general government.

6/ Based on averages for the last five years for the relevant variables (i.e., growth, interest rates).

7/ Overall balance plus debt amortization.

8/ Financial sector includes: commercial banks.

9/ A ratio of net profit to average assets.

$10 /$ A ratio of net profit to average capital. 


\begin{tabular}{|c|c|c|c|c|c|c|c|c|c|c|c|}
\hline & 2002 & 2003 & 2004 & 2005 & 2006 & 2007 & 2008 & 2009 & 2010 & 2011 & 2012 \\
\hline Real sector & \multicolumn{11}{|c|}{ (percent growth) } \\
\hline Real GDP & 1.9 & 3.6 & 4.5 & 6.4 & 6.4 & 5.9 & 4.6 & 5.2 & 4.3 & 4.0 & 3.9 \\
\hline Consumption & 3.5 & 6.3 & 1.0 & 2.3 & 3.9 & 4.8 & 3.0 & 2.9 & 3.0 & 3.2 & 3.2 \\
\hline Investment & 4.8 & -1.2 & 8.7 & -0.8 & 11.0 & 9.3 & 8.9 & 9.6 & 5.4 & 8.9 & 8.0 \\
\hline o/w fixed investment & 5.1 & 0.4 & 3.9 & 2.3 & 5.5 & 4.3 & 5.9 & 7.5 & 6.3 & 6.3 & 6.3 \\
\hline Exports, goods and services & 2.2 & 7.4 & 21.0 & 11.8 & 14.7 & 13.0 & 11.4 & 10.9 & 11.5 & 10.3 & 9.6 \\
\hline Imports, goods and services & 5.0 & 8.0 & 17.9 & 5.0 & 13.9 & 13.7 & 11.7 & 10.7 & 11.0 & 11.2 & 10.4 \\
\hline $\mathrm{CPI}$ inflation & 1.8 & 0.1 & 2.8 & 1.8 & 2.5 & 3.0 & 5.4 & 3.5 & 2.0 & 2.0 & 2.0 \\
\hline GDP deflator & 2.8 & 0.9 & 4.5 & -0.2 & 1.7 & 3.3 & 3.8 & 2.7 & 2.6 & 1.7 & 1.9 \\
\hline Gross domestic savings 2/ & 23.2 & 21.1 & 22.4 & 24.2 & 23.8 & 23.5 & 23.3 & 24.0 & 25.0 & 25.6 & 26.2 \\
\hline Public & -2.1 & -0.7 & 1.6 & 1.9 & 1.3 & 2.4 & 3.1 & 3.7 & 4.3 & 5.1 & 5.8 \\
\hline Private & 25.3 & 21.9 & 20.8 & 22.3 & 22.5 & 21.1 & 20.2 & 20.3 & 20.7 & 20.5 & 20.4 \\
\hline Gross capital formation 2/ & 28.7 & 27.4 & 27.6 & 25.8 & 26.9 & 26.9 & 26.8 & 27.3 & 27.7 & 28.4 & 29.2 \\
\hline Public finances $3 /$ & \multicolumn{11}{|c|}{ (in percent of GDP) } \\
\hline Revenues & 39.5 & 40.7 & 42.2 & 41.3 & 40.7 & 40.4 & 40.1 & 39.4 & 38.9 & 39.0 & 39.0 \\
\hline Expenditures & 46.3 & 47.3 & 45.1 & 44.9 & 43.6 & 43.2 & 42.3 & 41.5 & 41.4 & 41.3 & 41.3 \\
\hline Net lending & -6.8 & -6.6 & -2.9 & -3.5 & -2.9 & -2.8 & -2.2 & -2.1 & -2.5 & -2.3 & -2.3 \\
\hline General government debt & 28.5 & 30.1 & 30.4 & 30.2 & 30.1 & 29.5 & 28.9 & 28.4 & 28.5 & 28.7 & 29.0 \\
\hline Balance of payments & \multicolumn{11}{|c|}{ (in percent of GDP) } \\
\hline Current account balance & -5.5 & -6.2 & -5.2 & -1.6 & -3.1 & -3.4 & -3.5 & -3.3 & -2.7 & -2.8 & -3.0 \\
\hline Trade balance & -2.9 & -2.7 & -0.5 & 2.0 & 2.1 & 2.4 & 2.8 & 3.5 & 4.4 & 3.9 & 3.3 \\
\hline Services balance & 0.9 & 0.5 & 0.6 & 1.2 & 1.1 & 0.6 & 0.4 & 0.1 & -0.1 & -0.1 & -0.1 \\
\hline Net factor income & -4.7 & -4.7 & -5.6 & -5.2 & -5.7 & -5.8 & -5.2 & -5.9 & -5.8 & -5.7 & -5.3 \\
\hline Current transfers & 1.2 & 0.6 & 0.2 & 0.4 & -0.6 & -0.7 & -1.4 & -1.0 & -1.2 & -0.9 & -0.9 \\
\hline Financial account balance & 14.1 & 6.1 & 6.3 & 5.2 & 2.3 & 3.4 & 3.5 & 3.3 & 2.7 & 2.8 & 3.0 \\
\hline Capital transfers & 0.0 & 0.0 & -0.6 & 0.2 & 0.3 & 0.4 & 0.7 & 0.9 & 0.9 & 1.0 & 1.0 \\
\hline Direct investment, net & 11.0 & 2.1 & 3.6 & 9.4 & 3.2 & 4.1 & 4.0 & 3.7 & 3.6 & 3.6 & 3.1 \\
\hline $\mathrm{o} / \mathrm{w}$ privatization revenue & 5.2 & 0.9 & 0.5 & 0.8 & 0.0 & 0.0 & 0.0 & 0.0 & 0.0 & 0.0 & 0.0 \\
\hline Portfolio investment, net & -1.9 & -1.4 & 1.9 & -2.7 & -0.8 & -0.6 & -0.3 & -0.3 & -0.3 & -0.2 & -0.2 \\
\hline Financial derivatives, net & -0.2 & 0.1 & -0.1 & -0.1 & -0.2 & 0.3 & 0.0 & 0.0 & 0.0 & 0.0 & 0.0 \\
\hline Other investment, net & 5.2 & 5.3 & 0.9 & -1.4 & 0.0 & 0.0 & -0.2 & -0.1 & -0.7 & -0.6 & 0.1 \\
\hline Errors and omissions, net & 0.2 & 0.6 & -0.3 & -0.6 & 0.6 & 0.0 & 0.0 & 0.0 & 0.0 & 0.0 & 0.0 \\
\hline Change in reserves (- increase) $4 /$ & -8.8 & -0.5 & -0.2 & -3.1 & -0.1 & -0.4 & -0.7 & -0.9 & -0.9 & -1.0 & -1.0 \\
\hline
\end{tabular}

Sources: Czech Statistical Office, Czech National Bank, Ministry of Finance, and IMF staff estimates.

1/ Hyundai is expected to start a major new automobile plant in late 2008 which could contribute nearly a percentage point to GDP growth. These

considerations explain the volatility in staff's medium-term projections for GDP growth and trade balance.

2/ In percent of GDP.

3/ On ESA-95 basis.

4/ Changes in reserves reflect off-market conversion of large privatization receipts, EU transfers, and sales of accumulated interest. The projected increase in

reserves in 2008-12 is based on the expected increase in EU-fund transfers and the level of absorption of these transfers. 
Table 6. Czech Republic: External Debt Sustainability Framework, 2002-2012

(In percent of GDP, unless otherwise indicated)

\begin{tabular}{|c|c|c|c|c|c|c|c|c|c|c|c|c|}
\hline & \multicolumn{5}{|c|}{ Actual } & \multicolumn{7}{|c|}{ Projections } \\
\hline & 2002 & 2003 & 2004 & 2005 & 2006 & 2007 & 2008 & 2009 & 2010 & 2011 & 2012 & Debt-stabilizing \\
\hline 1 Baseline: External debt & 358 & 302 & 112 & $37 ?$ & 100 & 371 & 342 & & & 320 & & current account \\
\hline \multirow{2}{*}{2 Change in external debt } & & & & & & & & & & & & \\
\hline & -0.3 & 2.3 & 3.1 & -4.1 & 3.7 & -3.8 & -2.9 & -0.7 & -0.4 & -0.1 & -0.2 & \\
\hline 3 Identified external debt-creating flows $(4+8+9)$ & -11.5 & -2.4 & -4.1 & -10.9 & -4.0 & -0.4 & -2.1 & -2.3 & -2.5 & -2.3 & -2.1 & \\
\hline $4 \quad$ Current account deficit, excluding interest payments & 4.1 & 4.7 & 3.7 & 0.3 & 1.8 & 2.1 & 2.2 & 2.0 & 1.4 & 1.5 & 1.6 & \\
\hline Deficit in balance of goods and services & 2.1 & 2.2 & -0.1 & -3.2 & -3.2 & -3.1 & -3.2 & -3.6 & -4.3 & -3.8 & -3.2 & \\
\hline Exports & 60.5 & 61.8 & 70.1 & 71.8 & 76.1 & 82.1 & 85.8 & 89.7 & 95.2 & 101.2 & 106.8 & \\
\hline Imports & 62.6 & 64.1 & 70.0 & 68.5 & 72.9 & 79.0 & 82.7 & 86.1 & 90.9 & 97.4 & 103.5 & \\
\hline Net non-debt creating capital inflows (negative) & -10.7 & -2.4 & -3.0 & -7.5 & -2.3 & -1.8 & -4.2 & -3.9 & -3.9 & -3.9 & -3.9 & \\
\hline Automatic debt dynamics $1 /$ & -4.9 & -4.7 & -4.8 & -3.7 & -3.4 & -0.7 & -0.2 & -0.3 & 0.0 & 0.1 & 0.2 & \\
\hline Contribution from nominal interest rate & 1.5 & 1.6 & 1.5 & 1.3 & 1.4 & 1.3 & 1.3 & 1.3 & 1.3 & 1.3 & 1.4 & \\
\hline Contribution from real GDP growth & -0.6 & -1.1 & -1.4 & -2.3 & -2.1 & -2.0 & -1.4 & -1.6 & -1.3 & -1.2 & -1.2 & \\
\hline Contribution from price and exchange rate changes $2 /$ & -5.9 & -5.2 & -4.9 & -2.7 & -2.7 & $\ldots$ & $\ldots$ & 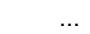 & $\ldots$ & $\ldots$ & 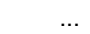 & \\
\hline 13 Residual, incl. change in gross foreign assets $(2-3) 3 /$ & 11.1 & 4.8 & 7.2 & 6.8 & 7.7 & -3.4 & -0.8 & 1.6 & 2.1 & 2.2 & 1.8 & \\
\hline External debt-to-exports ratio (in percent) & 59.2 & 61.8 & 58.8 & 51.8 & 53.8 & 45.2 & 39.8 & 37.3 & 34.7 & 32.5 & 30.6 & \\
\hline \multirow{2}{*}{$\begin{array}{l}\text { Gross external financing need (in billions of US dollars) } 4 / \\
\text { in percent of GDP }\end{array}$} & 16.9 & 19.8 & 27.1 & 25.3 & 26.6 & 34.6 & 39.6 & 44.0 & 46.3 & 50.4 & 55.3 & \\
\hline & 22.5 & 21.6 & 24.7 & 20.3 & 18.7 & 19.7 & 19.3 & 19.7 & 19.2 & 19.6 & 20.1 & \\
\hline \multicolumn{2}{|l|}{ Scenario with key variables at their historical averages 5 / } & & & & & 37.1 & 36.1 & 34.8 & 34.0 & 33.1 & 31.8 & -6.7 \\
\hline \multicolumn{13}{|l|}{ Key Macroeconomic Assumptions Underlying Baseline } \\
\hline Real GDP growth (in percent) & 1.9 & 3.6 & 4.5 & 6.4 & 6.4 & 5.9 & 4.6 & 5.2 & 4.3 & 4.0 & 3.9 & \\
\hline GDP deflator in US dollars (change in percent) & 19.5 & 17.1 & 14.7 & 7.0 & 7.8 & 16.6 & 11.5 & 3.4 & 3.5 & 2.8 & 3.0 & \\
\hline Nominal external interest rate (in percent) & 5.1 & 5.6 & 4.7 & 3.5 & 4.2 & 3.9 & 4.0 & 4.1 & 4.2 & 4.3 & 4.4 & \\
\hline \multirow{2}{*}{$\begin{array}{l}\text { Growth of exports (US dollar terms, in percent) } \\
\text { Growth of imports (US dollar terms, in percent) }\end{array}$} & 12.5 & 24.0 & 36.1 & 16.7 & 20.9 & 33.1 & 22.0 & 13.7 & 14.5 & 13.6 & 13.0 & \\
\hline & 12.2 & 24.2 & 31.2 & 11.6 & 21.3 & 33.7 & 22.0 & 13.3 & 13.9 & 14.5 & 13.8 & \\
\hline \multirow{2}{*}{$\begin{array}{l}\text { Current account balance, excluding interest payments } \\
\text { Net non-debt creating capital inflows }\end{array}$} & -4.1 & -4.7 & -3.7 & -0.3 & -1.8 & -2.1 & -2.2 & -2.0 & -1.4 & -1.5 & -1.6 & \\
\hline & 10.7 & 2.4 & 3.0 & 7.5 & 2.3 & 1.8 & 4.2 & 3.9 & 3.9 & 3.9 & 3.9 & \\
\hline
\end{tabular}

1/ Derived as $[r-g-\rho(1+g)+\varepsilon \alpha(1+r)] /(1+g+\rho+g \rho)$ times previous period debt stock, with $r=$ nominal effective interest rate on external debt; $\rho=$ change in domestic GDP deflator in US dollar terms, $\mathrm{g}=$ real GDP growth rate,

$\varepsilon=$ nominal appreciation (increase in dollar value of domestic currency), and $\alpha=$ share of domestic-currency denominated debt in total external debt.

$2 /$ The contribution from price and exchange rate changes is defined as $[-\rho(1+g)+\varepsilon \alpha(1+r)] /(1+g+\rho+g \rho)$ times previous period debt stock. $\rho$ increases with an appreciating domestic currency $(\varepsilon>0)$ and rising inflation (based on GDP deflator).

3/ For projection, line includes the impact of price and exchange rate changes.

4/ Defined as current account deficit, plus amortization on medium- and long-term debt, plus short-term debt at end of previous period.

5/ The key variables include real GDP growth; nominal interest rate; dollar deflator growth; and both non-interest current account and non-debt inflows in percent of GDP.

6/ Long-run, constant balance that stabilizes the debt ratio assuming that key variables (real GDP growth, nominal interest rate, dollar deflator growth, and non-debt inflows in percent of GDP) remain at their levels of the last projection year. 
Table 7. Czech Republic: Public Sector Debt Sustainability Framework, 2002-2012

(In percent of GDP, unless otherwise indicated)

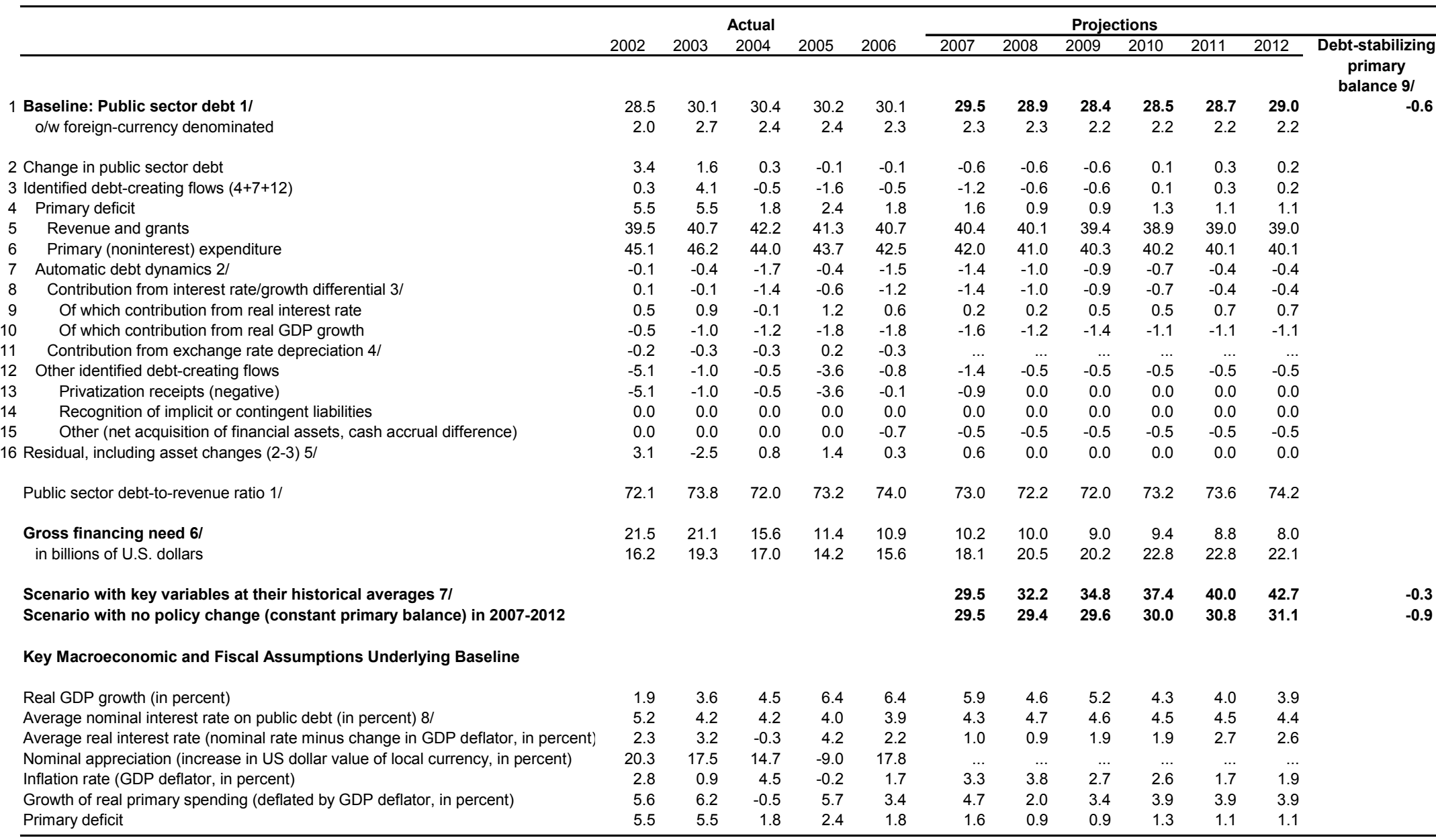

$1 /$ The coverage of public sector is the general government using data for gross debt.

2/ Derived as $[(r-\pi(1+g)-g+\alpha \varepsilon(1+r)] /(1+g+\pi+g \pi))$ times previous period debt ratio, with $r=$ interest rate; $\pi=$ growth rate of GDP deflator; $g=$ real GDP growth rate; $\alpha=$ share of foreign-currency

denominated debt; and $\varepsilon=$ nominal exchange rate depreciation (measured by increase in local currency value of U.S. dollar).

$3 /$ The real interest rate contribution is derived from the denominator in footnote $2 /$ as $r-\pi(1+g)$ and the real growth contribution as $-\mathrm{g}$.

$4 /$ The exchange rate contribution is derived from the numerator in footnote $2 /$ as $\alpha \varepsilon(1+r)$.

$5 /$ For projections, this line includes exchange rate changes.

6/ Defined as public sector deficit, plus amortization of medium and long-term public sector debt, plus short-term debt at end of previous period.

7/ The key variables include real GDP growth; real interest rate; and primary balance in percent of GDP.

7/ Derived as nominal interest expenditure divided by previous period debt stock.

9/ Assumes that key variables (real GDP growth, real interest rate, and other identified debt-creating flows) remain at the level of the last projection year.

CInternational Monetary Fund. Not for Redistribution 
INTERNATIONAL MONETARY FUND

CZECH REPUBLIC

Staff Report for the 2007 Article IV Consultation-Informational Annexes

Prepared by the European Department

January 7, 2008

Contents

Page

Appendixes

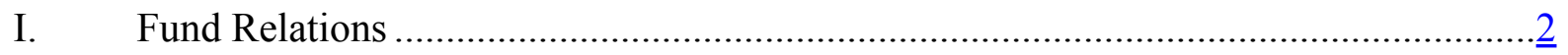

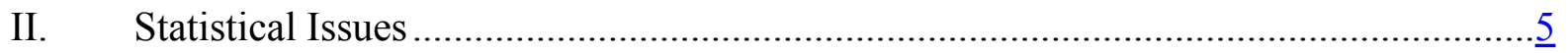




\section{Appendix I. Czech Republic: Fund Relations}

(As of October 31, 2007; unless specified otherwise)

I. Membership Status: Joined 1/01/1993; Article VIII

II. General Resources Account

Quota

Fund holdings of currency

Reserve position in Fund

III. SDR Department:

Holdings

\begin{tabular}{rr} 
SDR Million & \% Quota \\
\hline 819.30 & 100.0 \\
765.09 & 93.38 \\
54.21 & 6.62
\end{tabular}

$\underline{\text { SDR Million } \quad \text { Allocation }}$

$12.41 \quad$ N/A

IV. Outstanding Purchases and Loans: None

V. Financial Arrangements:

\begin{tabular}{|c|c|c|c|c|}
\hline Type & $\begin{array}{c}\text { Approval } \\
\text { Date }\end{array}$ & $\begin{array}{c}\text { Expiration } \\
\text { Date }\end{array}$ & $\begin{array}{c}\text { Amount } \\
\text { Approved } \\
\text { (SDR Million) }\end{array}$ & $\begin{array}{l}\text { Amount } \\
\text { Drawn } \\
\text { (SDR Million }\end{array}$ \\
\hline Stand-by & $\overline{3 / 17 / 1993}$ & $3 / \overline{16 / 1994}$ & 177.00 & 70.00 \\
\hline
\end{tabular}

VI. Projected Obligations to Fund: None

VII. Exchange Rate Arrangement:

The currency of the Czech Republic is the Czech koruna, created on February 8, 1993 upon the dissolution of the currency union with the Slovak Republic, which had used the Czechoslovak koruna as its currency. From May 3, 1993 to May 27, 1997, the exchange rate was pegged to a basket of two currencies: the deutsche mark ( 65 percent) and the U.S. dollar (35 percent). On February 28, 1996, the Czech National Bank widened the exchange rate band from \pm 0.5 percent to \pm 7.5 percent around the central rate. On May 27, 1997, managed floating was introduced. In the Annual Report on Exchange Arrangements and Exchange Restrictions, the de facto exchange rate regime of the Czech Republic is classified as managed floating with no predetermined path for the exchange rate. Since 2002 , the CNB has not engaged in direct interventions in the foreign exchange market. International reserves have been affected by the offmarket purchases of large privatization receipts and EU transfers and the sales of the accumulated interest. On December 13, 2007, the exchange rate of the Czech koruna stood at CZK 17.978 per U.S. dollar. 
The Czech Republic has accepted the obligations of Article VIII and maintains an exchange system that is free of restrictions on the making of payments and transfers for current international transactions. The Czech Republic maintains exchange restrictions for security reasons, based on UN Security Council Resolutions and Council of the European Union Regulations, that have been notified to the Fund for approval under the procedures set forth in Executive Board Decision No. 144-(52/51).

\section{Last Article IV Consultation:}

The last Article IV consultation with the Czech Republic was concluded on February 21, 2007. The staff report and PIN were published on February 28, 2007.

IX. Technical Assistance: See attached table.

X. Implementation of HIPC Initiative: Not Applicable

XI. Safeguards Assessments: Not Applicable

Czech Republic: Technical Assistance, 1991-2005

Department

FAD

MFD

February 1992

June 1992

July 1992

December 1992 and

February 1993
Regular visits by FAD consultant on VAT administration

Public financial management

Follow-up visit on public financial management

Follow-up visit on public financial management

Follow-up visit on public financial management

Follow-up visit by FAD consultant on VAT

administration

Follow-up visit on public financial management

Follow-up visit by FAD consultant on VAT

administration

Medium-term fiscal framework

Monetary management and research, foreign exchange operations, and banking supervision Monetary research

Long-term resident expert assignment in the area of banking supervision (financed by EC-PHARE; supervised by the Fund)

Bond issuance and monetary management 
December 1992 and

February 1993

November 1993

April 1994

January 1995

May 1995

May 1995

May 1996

April 1997

February-June 1999

June 1999

RES

STA
September 1999

June-August 2000

February-March 2005

May 1993

February 1994

April 1994

November 1994

January-February 1999

May 2002

February 2003

November 2006 supervised by the Fund)

Bond issuance and monetary management

Follow-up visit on bond issuance and monetary management and management of cash balances

Data management and monetary research

Foreign exchange laws (jointly with LEG) and external liberalization

Monetary operations

Banking system reform

Economic research

Banking legislation

Monetary research — inflation targeting

Integrated financial sector supervision (with WB)

Inflation targeting (financed by MFD)

Inflation targeting (financed by MFD)

Inflation targeting (financed by MFD)

Money and banking statistics

Balance of payments

Government finance

Money and banking statistics

Money and banking statistics

Monetary and financial statistics

Implementing GFSM 2001

GFSM 2001 Pilot Project 


\section{Appendix II. Czech Republic: Statistical Issues}

The Czech Republic subscribed to the Special Data Dissemination Standard (SDDS) in April 1998 and metadata and an annual observance report for 2006 are posted on the Fund's Dissemination Standards Bulletin Board. Data on core surveillance variables are available to the Fund regularly and with minimal lags (reporting to STA is less current, especially for foreign trade and the national accounts). Exchange rates and interest rates, set by the Czech National Bank (CNB), are reported daily with no lag. Gross and net international reserves are reported on a monthly basis with a one-week lag, as well as on a 10-day basis (with the CNB's balance sheet) with a one-week lag. Consumer prices, reserve money, broad money, borrowing and lending interest rates, central government fiscal accounts, and foreign trade are reported monthly with a lag of between one and four weeks. Final monetary survey data are available with a lag of about one month. GDP and balance of payments data are made available on a quarterly basis with a lag of two to three months. Since 2003, the main components of the balance of payments are also available monthly. Annual data published in the Government Finance Statistics Yearbook cover all operations of the general government, including the extrabudgetary funds excluded from the monthly data. These annual data are available on a timely basis. Monthly fiscal data published in International Financial Statistics (IFS) cover state budget accounts and are available with a two- to three-month lag.

1. While data quality is generally adequate, some deficiencies remain in certain areas and the authorities are taking measures to improve data accuracy.

- $\quad$ National accounts data are subject to certain weaknesses. Value added in the small-scale private sector is likely to be underestimated, as the mechanisms for data collection on this sector are not yet fully developed and a significant proportion of unrecorded activity stems from tax evasion. Discrepancies between GDP estimates based on the production method and the expenditure method are large and are subsumed under change in stocks. Quarterly estimates of national accounts are derived from quarterly reports of enterprises and surveys. The estimates are subject to bias because of nonresponse (while annual reporting of bookkeeping accounts is mandatory for enterprises, quarterly reporting is not) and lumping of several expenditure categories in particular quarters by respondents. Large swings in individual components of spending and the overall GDP from quarter to quarter bring into question the reliability of the quarterly data and hamper business cycle analysis.

- $\quad$ Recently, revisions to procedures for processing export data have brought external trade statistics close to the practice in the EU. However, a continued weakness of foreign trade statistics is the unavailability of fixed base price indices for exports and imports; these indices are currently presented on the basis of the same month of the previous year.

- Monetary survey data provided to the European Department are generally adequate for policy purposes. However, large variations in the interbank clearing account float, especially at the end of the year, require caution in interpreting monetary 
developments. The CNB has made a major effort to identify the causes of these variations and adjust the data. In 2002, to meet EU statistical conventions, the CNB implemented the European Central Bank's (ECB) framework for collecting, compiling, and reporting monetary data. The data published in IFS are based on monetary accounts derived from the ECB's framework. The same set of accounts also forms the basis for monetary statistics published in the CNB's bulletins and on the website, which are thereby effectively harmonized with the monetary statistics published in IFS, although the presentation in IFS differs somewhat from the CNB's.

- $\quad$ Annual fiscal data on ESA-95 basis has been prepared by the Czech Statistical Office. Quarterly data for non-financial accounts have also been compiled and quarterly financial accounts are being prepared. The Ministry of Finance uses the ESA-95 methodology for the Convergence Program targets. The ESA-95 methodology differs from the national (fiscal targeting methodology) in terms of the coverage of the institutions (for example, the CKA is included in the central government under ESA definition) and inclusion of financial transactions and other accrual items (for example, called guarantees). The Ministry of Finance participated in the Fund's pilot project to transition to the statistical methodologies outlined in Government Finance Statistics Manual, 2001. 


\section{Czech Republic: Table of Common Indicators Required for Surveillance As of December 17, 2007}

\begin{tabular}{|c|c|c|c|c|c|}
\hline & $\begin{array}{c}\text { Date of Latest } \\
\text { Observation }\end{array}$ & $\begin{array}{c}\text { Date } \\
\text { Received }\end{array}$ & $\begin{array}{c}\text { Frequency } \\
\text { of } \\
\text { Data }^{6} \\
\end{array}$ & $\begin{array}{l}\text { Frequency of } \\
\text { Reporting }\end{array}$ & $\begin{array}{l}\text { Frequency of } \\
\text { Publication }^{6}\end{array}$ \\
\hline Exchange Rates & $12 / 15 / 07$ & $12 / 15 / 07$ & $\mathrm{D}$ & $\mathrm{D}$ & $\mathrm{D}$ \\
\hline $\begin{array}{l}\text { International Reserve Assets and Reserve } \\
\text { Liabilities of the Monetary Authorities }{ }^{1}\end{array}$ & Nov. 2007 & $12 / 10 / 07$ & $\mathrm{D}$ & M & M \\
\hline Reserve/Base Money & 9/01/07 & $9 / 11 / 07$ & 10 days & 10 days & 10 days \\
\hline Broad Money & Sept. 2007 & $12 / 11 / 07$ & M & M & M \\
\hline Central Bank Balance Sheet & $9 / 01 / 07$ & $9 / 11 / 07$ & 10 days & 10 days & 10 days \\
\hline $\begin{array}{l}\text { Consolidated Balance Sheet of the } \\
\text { Banking System }\end{array}$ & Sept. 2007 & $12 / 11 / 07$ & M & M & M \\
\hline Interest Rates ${ }^{2}$ & Oct. 2007 & $11 / 16 / 07$ & $\mathrm{D}$ & $\mathrm{D}$ & $\mathrm{D}$ \\
\hline Consumer Price Index & Nov..2007 & $12 / 11 / 07$ & M & M & M \\
\hline $\begin{array}{l}\text { Revenue, Expenditure, Balance and } \\
\text { Composition of Financing }{ }^{3}-\text { General } \\
\text { Government }^{4}\end{array}$ & Dec 2006 & Jan 2007 & A & A & A \\
\hline $\begin{array}{l}\text { Revenue, Expenditure, Balance and } \\
\text { Composition of Financing }{ }^{3} \text { - Central } \\
\text { Government }\end{array}$ & Jul. 2007 & Sep 2007 & A & A & A \\
\hline $\begin{array}{l}\text { Stocks of Central Government and Central } \\
\text { Government-Guaranteed Debt }\end{array}$ & Jul. 2007 & Sep 2007 & A & A & A \\
\hline External Current Account Balance & 2007 Q2 & Aug 2007 & Q & Q & Q \\
\hline Exports and Imports of Goods and Services & Sept. 2007 & Dec 2007 & M & M & M \\
\hline GDP/GNP & 2007 Q3 & Dec 2007 & Q & Q & Q \\
\hline Gross External Debt & 2007 Q2 & Sep 2007 & $\mathrm{Q}$ & $\mathrm{Q}$ & $\mathrm{Q}$ \\
\hline
\end{tabular}

${ }^{1}$ Includes reserve assets pledged or otherwise encumbered as well as net derivative positions.

${ }^{2}$ Both market-based and officially-determined, including discount rates, money market rates, rates on treasury bills, notes and bonds.

${ }^{3}$ Foreign, domestic bank, and domestic nonbank financing.

${ }^{4}$ The general government consists of the central government (budgetary funds, extra budgetary funds, and social security funds) and state and local governments. Data for the state budget are available with monthly frequency and timeliness, while data on extra budgetary funds are available only on an annual basis.

${ }^{5}$ Including currency and maturity composition.

${ }^{6}$ Daily (D); Weekly (W); Monthly (M); Quarterly (Q); Annually (A); Irregular (I); Not Available (NA). 


\section{Statement by Willy Kiekens, Executive Director for the Czech Republic and Stanislav Polak, Senior Advisor to Executive Director January 23, 2008}

The Czech authorities would like to thank the IMF staff for another comprehensive and useful report. Salient features of this consultation include comprehensive tax and spending reforms decided by the government and the new monetary policy communication strategy adopted by the Czech National Bank (CNB).

The dialogue between the authorities and staff was constructive and candid. The joint conference on fiscal reforms, in which the public and private sectors and the academia participated, enabled an exchange of views with a broad professional audience on the staff's analytical work, which is included in the Selected Issues Paper. The involvement of experts from different areas was helpful in building consensus on fiscal reforms.

\section{Recent macroeconomic developments}

With output growth of 6 percent, the third quarter of 2007 was the $10^{\text {th }}$ consecutive quarter during which real GDP grew by at least 6 percent. GDP growth is now estimated to have been 6.2 percent in 2007 , considerably better than the 4.8 percent projected by staff or the 5.3 percent projected by the CNB last year.

Less positive is that annual inflation which reached 5.4 percent in December 2007, a peak since August 2001 and more than 2 percentage points above the projections made by the Fund and CNB one year ago.

The acceleration in inflation was the result of higher prices for food, alcoholic and nonalcoholic beverages, tobacco, transportation, restaurants and hotels. Rising food and energy prices worldwide make the surge in Czech inflation largely an exogenous cost-driven shock. The hike in food prices in the Czech Republic was however higher than that in neighboring countries. One factor could be that these prices were adjusted upwards in anticipation of the VAT increases that were to be implemented on January 1, 2008. The inflation outturn in January 2008 may confirm this analysis or indicate other factors that resulted in these late 2007 price increases such as higher demand pressures than those in neighboring countries or a weakening in competition. In any case, the CNB expects a further tightening of monetary policy. How much will the interest rates increase will depend on the size of the nominal exchange rate appreciation which effectively tightens monetary conditions. The most recent appreciation of the Czech Koruna overshoots the equilibrium exchange rate path estimated by the CNB.

High growth and lower unemployment have contributed to a favorable budget outcome, estimated to be a deficit of CZK 66.4 billion in 2007, or 1.9 percent of GDP. This was CZK 30 billion less than the deficit in the previous year and CZK 25 billion less than budgeted for 2007. Unused budget appropriations of CZK 79 billion were transferred to the reserve funds. 
For 2008, the Ministry of Finance has projected a general government budget deficit of 2.9 percent of GDP. However, in light of the 1.9 percent fiscal deficit in the previous year, the authorities are now considering to implement fiscal measures which will ensure more balanced macroeconomic conditions.

\section{Challenges of fiscal policy}

Since the new government took office in January 2007, it has expressed its commitment to bringing public finance to the original trajectory of a declining deficit and to closing the Excessive Deficit Procedure of the EU in a credible and sustained manner. With these goals, the September 2007 Act on Stabilization of Public Finances, primarily curbs mandatory expenditures by amending 49 laws and regulations. However, the authorities are aware of the need for further expenditure cuts in order to prepare the public finances for the cost of aging. Therefore, pension and health care systems and other mandatory expenditures will be further reformed before the next election in mid-2010. This will be a politically challenging task, because the government is supported by just 100 out of the 200 members of Parliament. Moreover, the better than expected fiscal outcome in 2007 carries the risk that Parliament becomes more complacent about the need for further fiscal consolidation.

Despite the cyclical improvement in the 2007 budget outcome, long-term fiscal sustainability remains a challenging policy issue. The government remains fully engaged in the preparations for reforming the pension and health care systems.

There is a three-pronged strategy for reforming the pension system. The first phase has been stabilizing the current pay-as-you-go system by parametric adjustments such as a gradual increase in the retirement age to 65 . The second phase aims at improving the protection of participants in second voluntary pension schemes, making them more attractive for workers and employers alike. The third phase of the strategy is to establish a voluntary savings pillar to which people could save and direct either full or part of their contributions under the staterun pay-as-you-go first pillar system. The political debate over the strategic issues with regard to the pension system, which was reopened in June 2007, is still ongoing.

The reform of the health care system will also be undertaken in several stages. The first phase is underway and aims at reducing the cost of the system for the public finances by introducing charges for doctors' visits, prescription drugs, hospitalization, and by curtailing the cost of medicines. The budget transfers to the health care system are now temporarily frozen. A panel of independent experts, set up in June 2007, is assessing the current state of the health care system and its viability. It remains to be seen, how soon it will be politically possible to implement that committee's recommendations.

The new government continues to improve transparency of public finances and to implement other institutional reforms needed to achieve its fiscal objectives. Key among them is the closing or integration of off-budget institutions. Tax and custom administrations will be gradually integrated, as will be the collection of social security and health insurance contributions. Both measures will reduce administrative costs. 


\section{Refinements of monetary policy communications}

The CNB's current inflation target of 3 percent was announced in March 2004 and took effect in January 2006. It was set marginally above the price stability level of the European Central Bank (ECB) for the euro area. The target level of 3 percent reflected specific features of a transforming economy converging towards the advanced countries. In March 2007, the CNB has announced a new inflation target of 2 percent with a tolerance band of \pm 1 percent, effective January 2010.

In recent years, the Czech economy has stabilized around its steady state. Given the gradual stabilization of the structure of consumption and the completion of the main "transformation" changes in the quality of consumer goods, the extent of statistical overestimation in the measurement of inflation is expected to decline gradually. Lower measured inflation should also be fostered by the fact that the new consumer basket, used since January 2007, has increased the weight of tradable unregulated commodities, whose prices are rising only slowly or even falling in the Czech Republic over the medium term. Also, inflation expectations have been anchored just below the CNB's current target of 3 percent. In this situation, moving to a lower inflation target will help achieve the Maastricht inflation criterion.

Since the launch of its inflation targeting strategy, the CNB has gradually increased the transparency of the Bank Board's monetary policy decision-making. Beginning 2008, the CNB will publish, in numerical form, the forecast-consistent path of its policy interest rates. This step will further enhance the transparency of the CNB's inflation forecast and will give external observers a better understanding of the CNB's monetary policy. However, this forecast is not a commitment by the CNB to future evolution of rates. Developments and new information that becomes available since the preparation of the forecast can cause the actual interest rate path to deviate from the previously forecast path. Like the forecast for other main variables, this uncertainty will be illustrated in a fan chart.

The CNB has decided to release the voting results of individual Board members on interest rate decisions. This will allow observers and the general public to better identify the opinions of each Board member and thus better understand the decisions of the Board as a whole. It will also give Board members more freedom to express their views in public. Increasing the accountability of individual board members will strengthen the principle of majority in the decision-making process of the Board.

\section{Prospects of euro adoption}

As an EU member without derogation, the Czech Republic is committed to adopting the euro once the Maastricht criteria are met. Its strategy for adopting the euro anticipated the country's joining the euro area in 2009 or 2010.

The Czech authorities annually assess whether economic conditions and nominal and real convergence are sufficiently aligned with the euro area. Based on an overall assessment, the Czech government has now concluded that only some of the preconditions for benefiting 
from the adoption of a single currency have already been met. The main obstacle to the fulfillment of the Maastricht criteria continues to be the medium-term prospects for public finances. The still limited flexibility of the labor market and an unsatisfactory entrepreneurial business environment represent a continuing risk for the smooth performance of the Czech economy within the European monetary union.

The euro adoption date will depend on the resolution of these obstacles. The Czech government is committed to making maximum reform efforts to resolve these problems by the end of its term. Only after successfully establishing the conditions for benefiting from adopting the euro will the Czech authorities announce the targeted adoption date and enter the ERM II for the minimum required length of time. 
Public Information Notice (PIN) No. 08/08 FOR IMMEDIATE RELEASE January 29, 2007
International Monetary Fund $70019^{\text {th }}$ Street, NW

Washington, D. C. 20431 USA

\section{IMF Executive Board Concludes 2007 Article IV Consultation with the Czech Republic}

On January 23, 2008, the Executive Board of the International Monetary Fund (IMF) concluded the Article IV consultation with the Czech Republic. ${ }^{1}$

\section{Background}

Economic performance remained strong in 2007, supported by continued robust growth of domestic demand. The current account deficit widened, but remained largely financed by inflows of direct investment. With vulnerabilities limited, the economy weathered the international financial market turmoil with minimal spillover impact. The strong economy boosted job creation while unemployment declined and capacity utilization reached record high levels. In this environment, inflation pressures mounted on account of higher domestic demand amid tightening labor markets as well as food and regulated price increases. Monetary policy was tightened in the second half of the year, although policy rates remain among the lowest in the EU.

Growth is projected to remain favorable, although its momentum will slow as the consumption boom decelerates and growth in the euro area weakens. Domestic demand will nevertheless remain the primary driver of growth as fixed investment rises. Risks to this growth outlook are mainly on the downside, stemming primarily from fragility of growth in major export markets following the ongoing financial market turbulence and continued euro appreciation.

\footnotetext{
${ }^{1}$ Under Article IV of the IMF's Articles of Agreement, the IMF holds bilateral discussions with members, usually every year. A staff team visits the country, collects economic and financial information, and discusses with officials the country's economic developments and policies. On return to headquarters, the staff prepares a report, which forms the basis for discussion by the Executive Board. At the conclusion of the discussion, the Managing Director, as Chairman of the Board, summarizes the views of Executive Directors, and this summary is transmitted to the country's authorities.
} 
Inflation is expected to almost double to above 5 percent, owing to food, energy and indirect tax increases, as well as demand and wage pressures. Risks of higher inflation expectations feeding into wage and price-setting remain while a slower pace of koruna appreciation could also increase inflation pressures. Shaping expectations is thus critical, especially with the planned lowering of the inflation target to 2 percent by 2010 .

Strong growth has resulted in a more favorable fiscal outturn than budgeted in 2007. Buoyant tax revenues have helped offset the large increase in spending on social benefits stemming from pre-election commitments. Starting in 2008, the government is implementing a fiscal reform program, which will introduce a flat tax on personal income and lower corporate income taxes, planned to be offset with VAT and excise tax increases, and a tightening of the wage bill and social benefits including through health care reforms. The fiscal stance is thus expected to turn restrictive in 2008 with the general government deficit budgeted at 2.9 percent of GDP. Over the medium term, the authorities plan to lower the structural deficit to 2.3 percent of GDP in 2010 and to 1 percent of GDP by 2012.

Competitiveness remained strong. Although the koruna has appreciated rapidly in recent months, it has remained broadly in line with fundamentals. Trade performance has been robust, with double-digit growth in export volume and rising export market shares in both the EU and world markets. The current account deficit has widened slightly owing to the repatriation of profits by large exporters.

Credit growth has continued at a brisk pace, albeit from a low base. High demand for mortgage loans, supported by the low interest environment and increasing household repayment capacity led to sustained household credit growth. The authorities plan to further integrate supervisory functions to strengthen the efficiency of supervision.

\section{Executive Board Assessment}

Executive Directors commended the authorities for the Czech economy's strong fundamentals, which have helped sustain the growth momentum with low unemployment, and underpin further strides toward convergence with the EU-15. Directors considered that sustaining this success in the face of a less benign global environment and rising supply constraints calls for a tight policy stance in the near term and steadfast commitment to sustainable fiscal consolidation and complementary structural reforms. Directors welcomed the authorities' updated euro accession strategy and their commitment to a sustained implementation of the Maastricht criteria, which would provide a solid foundation for euro adoption.

Directors commended the authorities on their prudent monetary policy, and supported the recent policy tightening to counter rising inflation pressures. With inflation set to rise to well above the target of 3 percent, Directors stressed the importance of ensuring that expectations remain well anchored to the inflation target through further timely monetary policy action. The appropriate pace of monetary tightening will depend, inter alia, on the degree of koruna appreciation and second-round effects of indirect tax and energy and food price increases. The 
planned downward shift in the inflation target to 2 percent from 2010 underscores the importance of preserving the Czech National Bank's high credibility. In this context, Directors encouraged the authorities to build further on welcome recent steps to enhance the transparency of monetary policy communication.

Directors welcomed the staff's assessment that the exchange rate of the koruna is broadly in line with fundamentals and consistent with external stability. Trade performance has been robust with rising export shares and the moderate current account deficit is financed largely by direct investment inflows.

While encouraged by the better-than-expected fiscal outturn for 2007, Directors noted that it largely reflected strong cyclical revenue gains. They recommended that such cyclical gains be saved and the underlying fiscal adjustment planned in the budget for 2008 implemented in full, leading to an appreciably better-than-budgeted deficit. Such prudence in 2008 would support the anti-inflationary stance of monetary policy and minimize the risk of breaching the targets for fiscal consolidation in 2009-10.

Directors broadly welcomed the modifications to the tax regime contained in the tax and welfare reform package recently approved by parliament-most notably the shift from direct to indirect taxation. At the same time, they considered that further measures would be needed to advance the goal of fiscal consolidation. Directors stressed that, in setting their fiscal priorities, the authorities will need to strike a careful balance between spending and revenue measures, and assign priority to the formulation of durable expenditure measures, since in the absence of such measures tax cuts could be ill-afforded.

Directors highlighted the important role of measures to promote labor participation and lower structural unemployment in alleviating fiscal adjustment. Directors therefore called for the adoption of targeted active labor market policies, easing regulations regarding hiring and dismissals, and an improved design of the tax-benefit system to enhance incentives to work. Directors noted that a more flexible labor market would also facilitate a smoother entry into the euro area. In this regard, they also encouraged further efforts to enhance business competitiveness.

In view of the coming challenge of population aging, Directors reiterated the importance of early and comprehensive pension and health care reforms. Along with the welcome increase in the retirement age to 65 years, complementary reforms to raise the effective retirement age and promote reliance on private pensions will also be needed. Directors welcomed the introduction of co-payments in health care as a step that should help contain excess demand pressures.

Directors viewed the Czech financial system as generally sound. They encouraged the authorities to ensure that household credit risks do not build up in an environment of rising 
interest rates and house prices. The large foreign presence of banks as well as the expected implementation of Basel II and the Markets in Financial Instruments Directive in 2008 call for enhanced coordination with foreign supervisors. Directors welcomed the financial authorities' efforts to further integrate supervisory functions.

Public Information Notices (PINs) form part of the IMF's efforts to promote transparency of the IMF's views and analysis of economic developments and policies. With the consent of the country (or countries) concerned, PINs are issued after Executive Board discussions of Article IV consultations with member countries, of its surveillance of developments at the regional level, of post-program monitoring, and of ex post assessments of member countries with longer-term program engagements. PINs are also issued after Executive Board discussions of general policy matters, unless otherwise decided by the Executive Board in a particular case. The staff report (use the free Adobe Acrobat Reader to view this pdf file) for the 2007 Article IV Consultation with the Czech Republic is also available. 
Czech Republic: Selected Economic Indicators, 2002-08

\begin{tabular}{|c|c|c|c|c|c|c|c|}
\hline & 2002 & 2003 & 2004 & 2005 & 2006 & 2007 & 2008 \\
\hline & & & & & & \multicolumn{2}{|c|}{ Staff Proj. } \\
\hline \multicolumn{8}{|l|}{ Real economy (change in percent) } \\
\hline Real GDP & 1.9 & 3.6 & 4.5 & 6.4 & 6.4 & 5.9 & 4.6 \\
\hline Domestic demand & 4.0 & 4.1 & 3.2 & 1.2 & 5.7 & 6.6 & 4.9 \\
\hline CPI (year average) & 1.8 & 0.1 & 2.8 & 1.8 & 2.5 & 3.0 & 5.4 \\
\hline PPI (year average) & -0.5 & -0.3 & 5.7 & 3.0 & 1.6 & n.a. & n.a. \\
\hline \multicolumn{8}{|l|}{ Unemployment rate (in percent) } \\
\hline Survey-based $1 /$ & 7.3 & 7.8 & 8.3 & 7.9 & 7.1 & 5.5 & 4.9 \\
\hline Registered 1/ & 9.2 & 9.9 & 9.8 & 8.9 & 8.1 & 6.4 & 5.8 \\
\hline Gross national savings (percent of GDP) & 23.2 & 21.1 & 22.4 & 24.2 & 23.8 & 23.5 & 23.3 \\
\hline Gross domestic investments (percent of GDP) & 28.7 & 27.4 & 27.6 & 25.8 & 26.9 & 26.9 & 26.8 \\
\hline \multicolumn{8}{|l|}{ Public finance (percent of GDP) 2/ } \\
\hline General government revenue & 39.5 & 40.7 & 42.2 & 41.2 & 40.8 & 40.4 & 40.1 \\
\hline General government expenditure & 46.3 & 47.3 & 45.1 & 44.8 & 43.8 & 43.2 & 42.3 \\
\hline Net lending & -6.8 & -6.6 & -2.9 & -3.5 & -2.9 & -2.8 & -2.2 \\
\hline General government debt & 28.5 & 30.1 & 30.4 & 30.2 & 30.2 & 29.5 & 28.9 \\
\hline \multicolumn{8}{|l|}{ Money and credit (end of year, percent change) } \\
\hline Broad money $3 /$ & 3.5 & 6.9 & 4.4 & 8.0 & 9.9 & 10.6 & n.a. \\
\hline Private sector credit (percent change, eop) $3 /$ & 4.5 & 11.8 & 15.3 & 20.8 & 21.6 & 25.9 & n.a. \\
\hline \multicolumn{8}{|l|}{ Interest rates (in percent, year average) } \\
\hline Three-month interbank rate $3 /$ & 2.6 & 2.1 & 2.6 & 2.2 & 2.6 & 3.6 & n.a. \\
\hline Ten-year government bond 4/ & 4.2 & 4.8 & 4.0 & 3.6 & 3.7 & 4.5 & n.a. \\
\hline \multicolumn{8}{|l|}{ Balance of payments (percent of GDP) } \\
\hline Trade balance & -2.9 & -2.7 & -0.5 & 2.0 & 2.1 & 2.4 & 2.8 \\
\hline Current account & -5.5 & -6.2 & -5.2 & -1.6 & -3.1 & -3.4 & -3.5 \\
\hline Gross international reserves (US\$ billion) & 23.7 & 27.0 & 28.4 & 29.6 & 31.5 & 34.0 & 37.0 \\
\hline Reserve cover (in months of imports of goods and services) & 6.1 & 5.5 & 4.5 & 4.1 & 3.6 & 2.9 & 2.6 \\
\hline \multicolumn{8}{|l|}{ Exchange rate } \\
\hline Nominal effective exchange rate, pa $(2000=100) 5 /$ & 116.5 & 116.8 & 118.0 & 125.3 & 131.7 & 136.5 & n.a. \\
\hline Real effective exchange rate, pa (CPI-based; $2000=100) 5 /$ & 118.7 & 116.8 & 118.3 & 125.3 & 132.3 & 138.0 & n.a. \\
\hline
\end{tabular}

Sources: Czech Statistical Office; Czech National Bank; Ministry of Finance; and IMF staff estimates and projections.

$1 /$ In percent of total labor force.

2/ On ESA-95 basis.

$3 /$ For 2007, data refer to October.

4/ For 2007, data refer to November.

5/ For 2007, data refer to September. 